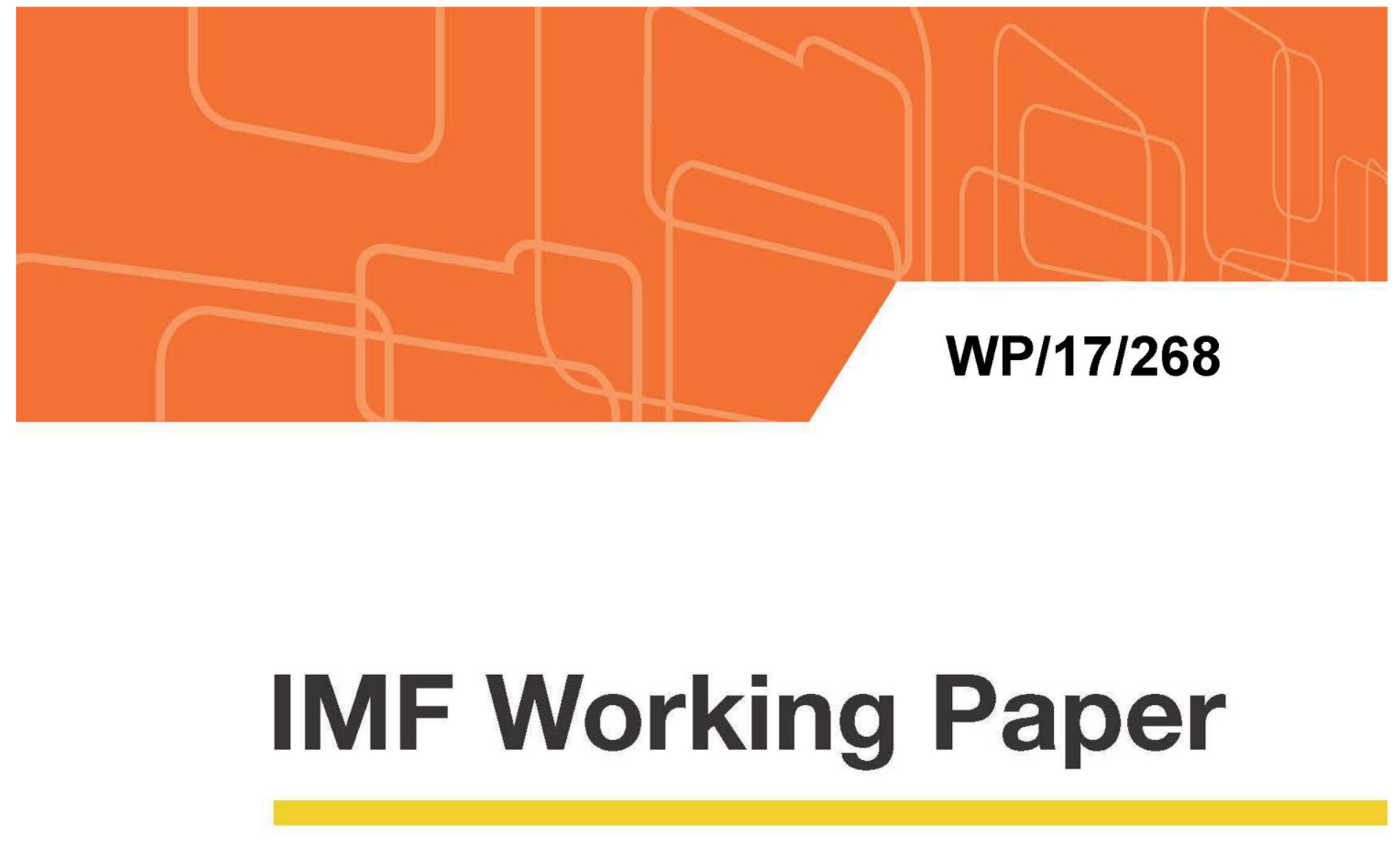

\title{
Unconventional Monetary Policy in a Small Open Economy
}

by Margaux MacDonald and Michał Ksawery Popiel

IMF Working Papers describe research in progress by the author(s) and are published to elicit comments and to encourage debate. The views expressed in IMF Working Papers are those of the author(s) and do not necessarily represent the views of the IMF, its Executive Board, or IMF management.

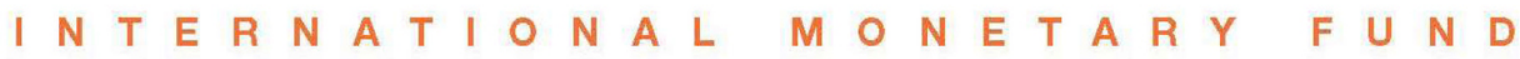




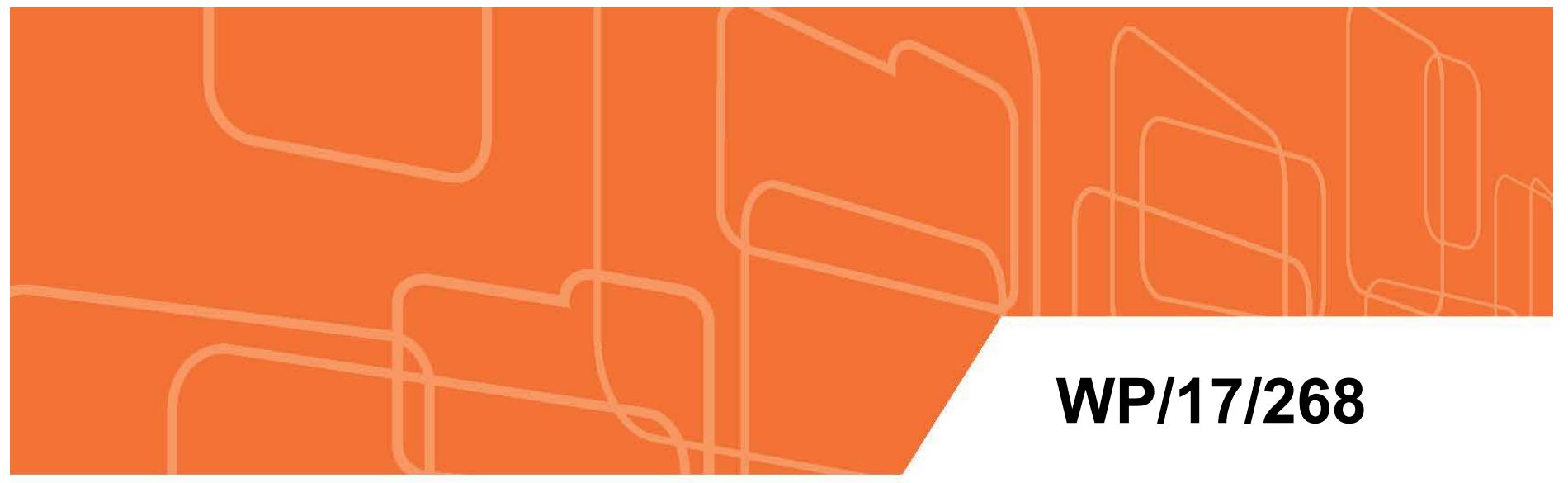

\section{IMF Working Paper}

\section{Unconventional Monetary Policy in a Small Open Economy}

by Margaux MacDonald and Michał Ksawery Popiel

IMF Working Papers describe research in progress by the author(s) and are published to elicit comments and to encourage debate. The views expressed in IMF Working Papers are those of the author(s) and do not necessarily represent the views of the IMF, its Executive Board, or IMF management. 


\title{
IMF Working Paper
}

\author{
African Department
}

\section{Unconventional Monetary Policy in a Small Open Economy ${ }^{1}$ Prepared by Margaux MacDonald and Michał Ksawery Popiel}

\author{
Authorized for distribution by Corinne C. Delechat
}

November 2017

\section{IMF Working Papers describe research in progress by the author(s) and are published to elicit comments and to encourage debate. The views expressed in IMF Working Papers are those of the author(s) and do not necessarily represent the views of the IMF, its Executive Board, or IMF management.}

\begin{abstract}
This paper investigates the effects of unconventional monetary policy in a small open economy. Using recently proposed shadow interest rates to capture unconventional monetary policy at the zero lower bound (ZLB) we estimate a Bayesian structural vector autoregressive model for Canada - a useful case where foreign shocks can be proxied by U.S. variables alone. We find that, during the ZLB period, Canadian unconventional monetary policy increased output (measured by industrial production) by 0.013 percent per month on average while US unconventional monetary policy raised Canadian output by 0.127 percent per month on average. Our results demonstrate the effectiveness of domestic unconventional monetary policy and the strong positive spillover effects that foreign unconventional monetary policies can have in a small open economy.
\end{abstract}

JEL Classification Numbers: E52, E58, F42.

Keywords: Small open economy; unconventional monetary policy; Bayesian structural VAR; zero lower bound; international monetary policy transmission.

Author's E-Mail Address: mmacdonald@imf.org; popielm@econ.queensu.ca

\footnotetext{
${ }^{1}$ We thank Gregor Smith, Allan Gregory, Morten Nielsen, an anonymous referee from the Bank of Canada's student paper award competition, IMF staff, seminar participants at the Bank of Canada, Midwest Macro Meetings, Canadian Economics Association Meeting, and Queen's University for thoughtful and constructive comments. This research was supported by the Donald S. Rickerd Fellowship in Canadian-American Studies and the Bank of Canada PhD internship program. The views presented in this paper are our own and do not necessarily reflect those of the International Monetary Fund, Bank of Canada or its governing council.
} 


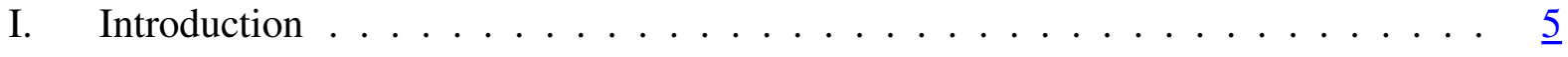

II. Measuring unconventional monetary policy $\ldots \ldots \ldots \ldots \ldots$

A. Shadow rates . . . . . . . . . . . . . . . . . . 10

B. Event study . . . . . . . . . . . . . . . . . . . . 12

III. Small open economy B-SVAR model . . . . . . . . . . . . . . . . $\underline{16}$

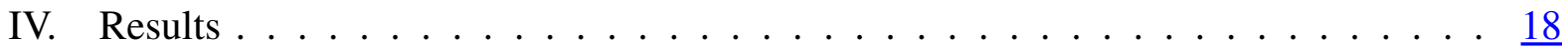

A. Monetary Policy Shocks . . . . . . . . . . . . . . . . $\underline{18}$

B. Effects of unconventional monetary policy . . . . . . . . . . 22

1. Restricted monetary policy in Canada . . . . . . . . . . . . 22

2. Restricted monetary policy in the US . . . . . . . . . . . $\underline{24}$

V. Robustness . . . . . . . . . . . . . . . . . . . 27

A. Government expenditure . . . . . . . . . . . . . . $\underline{28}$

B. Using a Taylor Rule . . . . . . . . . . . . . . . . . . . $2 \underline{29}$

C. Current Account . . . . . . . . . . . . . . . . . . . $\underline{38}$

D. Alternative Exclusion Restrictions . . . . . . . . . . . . . . $4 \underline{42}$

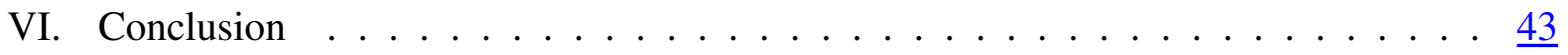

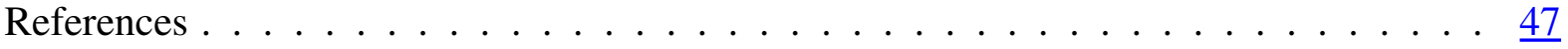

Appendices

A. Data ........................

B. Alternative Confidence Bands . . . . . . . . . . . . . $\underline{53}$

C. Robustness - Government Expenditure Model, 68 \% Confidence Bands . . . . . . . $\underline{56}$

D. Robustness - Bank of Canada Reaction Function . . . . . . . . . . . . . . $\underline{58}$

Tables

1. Bank of Canada announcements and shadow short rate changes . . . . . . . . 14

2. Effect of Bank of Canada Announcements on Shadow Short Rate . . . . . . . . . $\underline{15}$

3. Average Counterfactual Path for ZLB . . . . . . . . . . . . . . $\frac{26}{26}$

4. Average Counterfactual Path for ZLB, Government Expenditure Model . . . . . . $\underline{33}$

5. Average Counterfactual Path for ZLB, Taylor Rule . . . . . . . . . . . . . $\underline{40}$

6. Average Counterfactual Path for ZLB, Current Account Model . . . . . . . . . . $\frac{45}{52}$

7. Data Sources and Definitions . . . . . . . . . . . . . . . . $\underline{52}$

8. Average Counterfactual Path for ZLB $(90 \%$ confidence band $) \ldots \ldots \ldots \underline{55}$ 
Figures

1. Canadian and US Policy Rates 1994-2016 . . . . . . . . . . . . . . . . 13

2. Impulse Response Functions: Canadian Monetary Policy Shock . . . . . . . . . . $\underline{19}$

3. Impulse Response Functions: US Monetary Policy Shock . . . . . . . . . . . . . . 20

4. Counterfactual Paths: Canadian ZLB Imposed . . . . . . . . . . . . . . . . 23

5. Counterfactual Paths: US ZLB Imposed . . . . . . . . . . . . . . . . . . 25

6. Impulse Response Functions: Canadian Monetary Policy Shock, Government Expenditure Model . . . . . . . . . . . . . . . . . . . . . 29

7. Impulse Response Functions: US Monetary Policy Shock, Government Expenditure Model . . . . . . . . . . . . . . . . . . . . . $\underline{30}$

8. Counterfactual Paths: Canadian ZLB Imposed, Government Expenditure Model . . $\underline{31}$

9. Counterfactual Paths: US ZLB Imposed, Government Expenditure Model . . . . . $\underline{32}$

10. Canadian and US Policy Rates and Taylor Rule Rates1994-2016 . . . . . . . . . . $\underline{34}$

11. Impulse Response Functions: Canadian Monetary Policy Shock, Taylor Rule . . $\underline{36}$

12. Impulse Response Functions: US Monetary Policy Shock, Taylor Rule . . . . . . . 37

13. Counterfactual Paths: Canadian ZLB Imposed, Taylor Rule . . . . . . . . . . . . . . . . . . . .

14. Counterfactual Paths: US ZLB Imposed, Taylor Rule . . . . . . . . . . . . . . 39

15. Impulse Response Functions: Canadian Monetary Policy Shock, Current Account

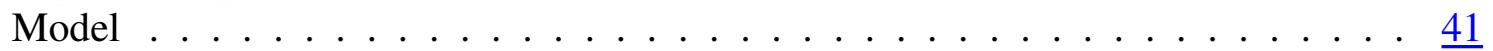

16. Impulse Response Functions: US Monetary Policy Shock, Current Account Model . $\underline{42}$

17. Counterfactual Paths: Canadian ZLB Imposed, Current Account Model . . . . . . . 43

18. Counterfactual Paths: US ZLB Imposed, Current Account Model . . . . . . . . . . 44

19. Counterfactual Paths: Canadian ZLB Imposed (90\% confidence band) . . . . . . . $\underline{53}$

20. Counterfactual Paths: US ZLB Imposed (90\% confidence band) . . . . . . . . . . 54

21. Impulse Response Functions: Canadian Monetary Policy Shock, Government Expenditure Model . . . . . . . . . . . . . . . . . 5 56

22. Impulse Response Functions: US Monetary Policy Shock, Government Expenditure Model . . . . . . . . . . . . . . . . . . . . . . . . 57

23. Impulse Response Functions: Canadian Monetary Policy Shock, Alternative Exclusion Restrictions 1 . . . . . . . . . . . . . . . . . . . . 58

24. Impulse Response Functions: US Monetary Policy Shock, Alternative Exclusion Restrictions $1 \ldots \ldots \ldots \ldots \ldots$. . . . . . . . . . . . . . . . . . . . . . .

25. Counterfactual Paths: Canadian ZLB Imposed, Alternative Exclusion Restrictions $1 \quad \underline{60}$

26. Counterfactual Paths: US ZLB Imposed, Alternative Exclusion Restrictions 1 . . . $\underline{61}$ 


\section{INTRODUCTION}

Following the 2008 global financial crisis, many central banks quickly exhausted their ability to stimulate economic activity as policy rates reached the zero lower bound (ZLB). ${ }^{2}$ To continue to encourage lending, they turned to unconventional measures, including direct market interventions through large scale asset purchases (LSAPs) and forward guidance, to influence expectations of the future short rate. Recent literature has quantified the effects of these policies on long term rates, asset prices, credit costs and (to a lesser extent) the real economy, and has generally focused on the domestic effects of such policies in large open economies, most notably the US. ${ }^{3}$ In contrast, this paper analyzes the effects of unconventional monetary policy measures in a small open economy, including spillovers from foreign unconventional monetary policy, a topic which has hitherto received relatively little attention. ${ }^{4}$ Specifically, we look at the case of Canada, for reasons explained below, and measure the effects of the Bank of Canada and Federal Reserve's unconventional monetary policies at the ZLB on the real economy.

There are two main challenges that we face in conducting our analysis, both of which can be addressed by studying the Canadian case. First, small open economies often respond strongly to foreign shocks. Therefore, to gain meaningful insight into the role of domestic monetary policy we must control for international variables. International spillovers to Canada, among several candidate small open economies that engaged in unconventional monetary policy following the global financial crisis, can be mostly captured by US variables. This greatly simplifies our analysis. Moreover, since the Canadian economy is relatively small, we can assume that domestic shocks have little impact on the US. That is, there are no "spillback" effects from Canada to the US, which allows us to isloate a single direction of international spillovers. In fact there is evidence that globally, monetary policy spillovers tend to be onedirectional from the US to abroad, with limited evidence of spillbacks even from other large open economies. ${ }^{5}$ We impose this single-direction spillover assumption via block-exogeneity restrictions à la Cushman and Zha (1997) in a two-country Bayesian structural vector autore-

\footnotetext{
${ }^{2}$ We define the ZLB as 25 basis points (bps), consistent with central bank definitions in 2008.

${ }^{3}$ See, for example, Hamilton and Wu (2012), Swanson and Williams (2014), D' Amico and King (2013), Krishnamurthy and Vissing-Jorgensen (2011), and Gagnon, Raskin, Remache, and Sack (2010), among others, for studies that look at the impact on interest rates, term spreads, asset prices, and credit costs, and Dahlhaus, Hess, and Reza (2014) and Gambacorta, Hofmann, and Peersman (2014) for studies that look at the impact on the real economy.

${ }^{4}$ Note that there is a large literature on Japanese unconventional monetary policy from the early 2000s, which is separate from the literature we refer to here that is focused on unconventional monetary policy during the global financial crisis. See Bernanke and Reinhart (2004) for an overview.

${ }^{5}$ See Rogers, Scotti, and Wright (2014) and Ehrmann and Fratzscher (2005).
} 
gressive (B-SVAR) model. Structural autoregression (SVAR) models with block-exogeneity restrictions have been used to study the impact of US monetary policy shocks on the Euro Area (Neri and Nobili, 2010), on Latin American countries (Canova, 2005), on a range of emerging markets (Maćkowiak, 2007), and on Canada (using alternative model characterizations and estimation methods) (Bhuiyan (2012) and McNeil (2017)). Block-exogeneity assumptions can also been useful in non-monetary policy spillover models, such as models of global commodity shocks on small open economies (Charnavoki and Dolado, 2014).

Second, capturing the stance of monetary policy is complicated by the fact that there is no variation in the target interest rate - the standard choice for a policy variable - at the ZLB. To get around this problem, the literature provides two alternatives: event study methods or SVAR models with a different policy variable such as the central bank balance sheet (Dahlhaus, Hess, and Reza, 2014; Gambacorta, Hofmann, and Peersman, 2014; MacDonald, 2017), the term spread (Baumeister and Benati, 2013) or a shadow rate (Krippner, 2013; Wu and Xia, 2016). Event studies isolate monetary policy shocks that are not contaminated by any other important events by focusing on the response around a very short time interval. While insightful on the immediate response of financial variables, event studies are unable to capture the effects on real variables because their response is much slower. Additionally, they capture only changes in market expectations that occur within the specified time interval, which itself may be misspecified. Using the central bank balance sheet as a policy variable in an otherwise standard SVAR directly tackles this issue. However, the balance sheet only captures the implementation of LSAPs and does not reflect either their announcements, which have been shown to have a significant stimulating effect on the economy, nor other policies such as forward guidance. ${ }^{6}$ The term spread captures the effect of both announcements and LSAPs but by measuring these effects through the compression of the yield curve it cannot be constructed as an uninterrupted variable through conventional and unconventional episodes (as is also the case with the balance sheet variable). Moreover, any estimation of counterfactuals using the term spread rely on outside estimates of the effects of LSAPs on the spread. Given the limitations of these methods, we adopt the remaining alternative and define the policy variables using estimated shadow interest rates, which uses the term structure of interest rates to predict the level of the short-term rates as if they were not bound by zero.

\footnotetext{
${ }^{6}$ Krishnamurthy and Vissing-Jorgensen (2011) and Gagnon and others (2010) show unconventional monetary policy announcements had significant impacts on US financial markets. Neely (2015), Chen, Filardo, He, and Zhu (2015), and Bowman, Londono, and Sapriza (2015) show that unconventional monetary policy announcements had significant impacts on foreign country financial markets. Eichengreen and Gupta (2014), and Dahlhaus and Vasishtha (2014) show the same is true for unconventional monetary policy tapering announcements.
} 
Although the use of shadow rates comes at a cost of not being able to disentangle the effects of specific policies, it has several distinct advantages. The shadow rate provides a consistent measure of monetary policy stance for both central banks in our empirical model. Since the Bank of Canada's unconventional monetary policy measures did not include LSAPs, the shadow rate is more appropriate than the balance sheet as a policy variable. Furthermore, its flexibility also makes it appropriate as a policy variable for the Federal Reserve (the Fed) because it captures the effects of both forward guidance and LSAPs. Moreover, since the shadow rate can be viewed as an extension of the traditional policy variable uninterrupted by the ZLB, we are able to begin our sample long before the ZLB episode and use the additional observations to improve the precision of our results.

We estimate our model for the period 1994-2016 and quantify the impact of unconventional monetary policies through counterfactual experiments that restrict the shadow rate to the ZLB. Our main finding is that Canadian unconventional monetary policy had expansionary effects on the Canadian economy, boosting output (which we proxy by industrial production) by approximately 0.013 percent per month on average during the ZLB episode. This result is robust to several different specifications. Our setup also allows us to investigate the effects of US unconventional monetary policies on the Canadian economy, and we find that Canadian output (industrial production) would have been approximately 0.127 percent lower per month on average without US unconventional monetary policies.

Our paper is related to a strand of literature that measures US unconventional monetary policy spillovers: Fratzscher, Lo Duca, and Straub (2013) analyze the impact of 12 key quantitative easing $(\mathrm{QE})$ announcements by the Fed and find that they lowered sovereign yields and raised equity prices, but that there was substantial heterogeneity in the effects on emerging market versus advanced economies. Fratzscher, Lo Duca, and Straub (2014) perform a similar analysis for European Central Bank QE announcements. Bauer and Neely (2014) use an event study to identify international transmission channels of unconventional US monetary policy. They find that the LSAPs decreased Canadian long-term yields significantly through both signalling and portfolio balance channels. Neely (2015) also uses an event-study and finds large effects on Canadian yields and on the exchange rate. Dahlhaus, Hess, and Reza (2014) use a factor-augmented VAR (FAVAR) model and the Fed's balance sheet as the policy instrument to evaluate spillovers from US QE on the Canadian economy. They find that QE had a positive impact on Canadian output and that Canadian asset prices and interest rates move in tandem with their US counterparts. Our analysis is distinct from these as we model domestic monetary policy in the US, and, by using the shadow rate, we incorporate both the unconven- 
tional monetary policy announcement and large scale asset purchase spillovers from the US to Canada.

Also related is a large literature on international conventional monetary policy spillovers. Among these, Dedola, Rivolta, and Stracca (2017) show that surprise US monetary tightening leads to US dollar appreciation and, in foreign countries, a fall in GDP and in inflation, and a rise in unemployment (albeit with significant heterogeneity across countries). Bruno and Shin (2015) show that a monetary policy loosening leads to dollar depreciation, which is transmitted through the leverage cycle (or the "risk-taking" channel of monetary policy). In the same vein, Cecchetti, Griffoli, and Narita (2017) show that leverage ratios and risk-taking rise in foreign countries when both their domestic monetary policy, and US monetary policy, eases.

The effects of unconventional monetary policy is thus an ongoing area of active research (for a review see Kozicki, Santor, and Suchanek (2011), Krishnamurthy, Vissing-Jorgensen and others (2013), Santor and Suchanek (2016), and references therein) and although most empirical evidence suggests that unconventional policies had expansionary effects, the magnitude of these effects depends on many factors, particularly in a small open economy, and is difficult to generalize, highlighting the need for studying individual cases where it is possible to quantify these effects more precisely, such as the one considered in this paper.

Recent concerns about the large adverse cross-border spillovers of unconventional monetary policies have rekindled the discussion of international coordination of monetary policy (Engel, 2015; Taylor, 2013). It has been argued that countries who are responsible for substantial international monetary policy spillovers should acknowledge their role in influencing foreign economies, and should consider feasible remedies to limit negative spillovers (Blanchard, Ostry, and Ghosh, 2013; Mishra and Rajan, 2016). Our work contributes to an alternative perspective on unconventional monetary policy spillovers: that under certain circumstances, in particular when international monetary policy is coordinated, such spillovers can be favourable. This literature, and our contribution, is also linked to global financial cycles and their spillovers. This literature is reviewed by IMF (2017), who show that stronger financial linkages with the US increase the sensitivity of domestic financial conditions to global shocks, but that overall countries are still able to steer their domestic financial conditions. In related work, Rey (2015) demonstrates that US monetary policy has spillovers globally regardless of domestic macroeconomic conditions and Obstfeld (2015) shows that emerging markets are particularly impacted by foreign monetary policy, regardless of the exchange rate regime. In addition, Caceres, Carriere-Swallow, Demir, and Gruss (2016) show that the re- 
sponse of domestic interest rate globally depend on changes in US interest rates, how much autonomy the monetary authorities have, and the exchange rate regime in place.

Finally, our analysis is also related to studies quantifying the effects of unconventional monetary policy measures in Canada. He (2010) showed that the Bank of Canada's conditional commitment on interest rates effectively reduced yields (albeit not statistically significantly). Chang and Feunou (2013) and found that forward guidance, the expansion of liquidity, and policy rate cuts successfully reduce market volatility. Gambacorta, Hofmann, and Peersman (2014) used central bank balance sheets in seven countries to assess the effectiveness of monetary policy at the ZLB domestically, and found that a positive shock to the balance sheet increased economic activity and consumer prices but the effect on inflation was weaker and less persistent. Our paper is distinct from these cited papers in two important ways: first they do not control for potential spillovers from the US or elsewhere and second, they do not evaluate the total effect of all unconventional monetary policies during the ZLB, as our shadow rate does.

This paper is structured as follows. The next section describes our measure of unconventional monetary policy. Section III presents the data and method. Our main analysis, which studies the effect of Canadian and US monetary policy on the Canadian economy from 1994-2016, is discussed in Section IV. We conduct several robustness exercises, by considering alternative model specifications in Section V. Section VI concludes.

\section{MEASURING UNCONVENTIONAL MONETARY POLICY}

On April 212009 the Bank of Canada, in coordination with other central banks, lowered the target rate from $50 \mathrm{bps}$ to $25 \mathrm{bps}$, considered at the time its effective lower bound, reduced the operating band from $50 \mathrm{bps}$ to $25 \mathrm{bps}$, and thereby set the target rate to the lower bound (25 bps). ${ }^{7}$ Aiming to reduce uncertainty in Canadian financial markets, the Bank of Canada committed to keep the target rate unchanged until the end of the second quarter of 2010, conditional on inflation expectations. It further reinforced the upper bound on the operating band (50 bps) through its standing liquidity facility (SLF), which provided access to overdraft loans at the bank rate for the Bank's Large Value Transfer System (LVTS) participants, and by prorating access to new standing purchase and resale agreements (PRAs) at the bank rate

\footnotetext{
${ }^{7}$ The Bank of Canada operates under a 2 percent inflation target by adjusting (or not) the overnight rate (the "target rate") at eight fixed announcement dates annually.
} 
for Canadian primary dealers. ${ }^{8}$ The Bank of Canada reinforced the lower bound on the operating band by providing LVTS participants with access to a standing deposit facility on which they could earn the deposit rate and by conducting sale and repurchase agreements (SRAs) intraday at 25 bps with primary dealers, if required. Finally, it targeted daily settlement balance levels at $\$ 3$ billion, a dramatic increase from the small positive balance target during conventional times (Bank of Canada, 2010). With market conditions improving, the Bank of Canada removed its statement of commitment on April 20 2010. On June 12010 the target rate was raised to $50 \mathrm{bps}$, and the standard operating framework was reestablished.

In the US, the federal funds rate reached the ZLB in December 2008 at which point the Fed began engaging in unconventional monetary policies, including LSAP purchases, a commitment to continue the LSAP program, and a commitment to keep the policy rate at the ZLB. LSAPs involved purchases of asset with medium- and long-term maturities, including US Treasuries, mortgage-backed securities, Federal agency debt, and currency swaps, and were meant to lower the cost of long-term private borrowing, or flatten yield curves. The Fed conducted several rounds of LSAPs: QE1 (December 2008-March 2010), QE2 (November 2010-June 2011), and QE3 (September 2012-October 2014). ${ }^{9}$ The Fed's commitment to LSAPs and the 0-25 bps rate range was meant to reduce uncertainty in US financial markets and stimulate the economy. Importantly, the central bank target rate did not reflect any of these actions because it remained at the ZLB throughout. On December 16, 2015 the Fed moved away from the ZLB for the first time since 2008 by increasing the federal funds rate to 50 bps.

\section{A. Shadow rates}

We define the Canadian and US policy variables a using shadow rate term structure model (SRTSM), first proposed by Black (1995), which provides a consistent measure of monetary policy stance for both central banks at and away from the ZLB. The model defines the observed nominal rate, $r_{t}$, as the sum of an unobserved and unrestricted shadow rate (which can be less than zero), $s r_{t}$, and the option value of holding physical currency that is exercised at

\footnotetext{
${ }^{8}$ The Bank of Canada targets the overnight rate in the LVTS, which allows transfers of large payments with a guarantee of settlement.

${ }^{9}$ The Fed also conducted Operation Twist in September 2011, which involved purchases of bonds with longterm maturities and sales of bonds with short-term maturities. This operation left the overall size of the Fed's balance sheet unchanged.
} 
the effective lower bound, $\underline{r}$. Specifically,

$$
r_{t}=\max \left\{s r_{t}, \underline{r}\right\}=s r_{t}+\underbrace{\max \left\{0, \underline{r}-s r_{t}\right\}}_{\text {option value of currency }}
$$

Only when the shadow rate is below the ZLB is the currency option positive. Fitting this model to the data allows one to back out an estimate of the shadow rate process.

There are several benefits to using the shadow rate as a measure of unconventional monetary policy. First, the shadow rate captures both the signalling and portfolio balance channels of central banks actions. While the Fed's LSAPs were meant to flatten yield curves, Fed announcements were meant to reduce both future rate expectations and uncertainty in financial markets. Measuring monetary policy by either the balance sheet or Fed announcements alone would then only capture one of the two channels. By taking information from the entire yield curve, the shadow rate captures both channels as well as forward guidance and other actions at the ZLB. Second, the shadow rate provides us with an uninterrupted measure of monetary policy through conventional and unconventional ZLB episodes. This allows for more precise estimation as we can extend the time series beyond the ZLB period.

While Krippner (2012, 2013) and Bauer and Rudebusch (2013) use numerical simulation methods to solve for the rate, $\mathrm{Wu}$ and Xia (2016) take an alternative approach and derive an apporixmate solution to the shadow rate as a function of the yield curve and the probability that the shadow rate will fall below the effective lower bound. Since the latter method provides a tractable analytical approximation of the shadow rate, and does not require numerical simulation, it is our preferred approach. Moreover, Wu and Xia (2016) estimate more conservative values for the US shadow rate relative to those from Krippner $(2012,2013)$, so that our results could be interpreted as a lower bound. We take the Wu and Xia (2016) estimate of the US shadow rate directly, and we adopt their method to estimate a Canadian shadow rate. To our knowledge, we are the first to report estimates for a Canadian shadow rate during the 2009-10 ZLB period.

For both countries we assume the ZLB is at $25 \mathrm{bps}$, consistent with the lower bound both central banks set interest rate to and with the prevailing assumption of what the ZLB threshold was during this period. While several European central banks later set interest rates below zero, in the case of Canada and the US assuming a ZLB below 25 bps would misattribute UMP actions taken during this period, and thereby captured by the shadow rate, to conventional policy. 
Figure 1 plots our estimated Canadian shadow rate and the US shadow rate, spliced with the Bank of Canada target rate and federal funds target rates when these policy rates were at the ZLB. The Canadian shadow rate reached a low of approximately -0.34 percent in November 2009, at which point the Bank of Canada was midway through its conditional commitment mandate and was actively engaging in liquidity provision activities. The US shadow rate was decreasing from 2008 through 2014, reaching a low of -2.99 percent. Throughout this period the Fed engaged in three rounds of QE and made numerous statements regarding continued policy easing.

\section{B. Event study}

Since we are the first to estimate a shadow rate for Canada, we begin by assessing whether its movements are consistent with the actions taken by the Bank of Canada during the ZLB. ${ }^{10}$ Specifically, we conduct an event study around Bank of Canada policy announcements. We note, however, that our shadow rate can be estimated at a daily frequency at most, given the Bank of Canada's zero coupon bond yield curve data which is daily frequency. This may be considered too low a frequency to identify any effects from central bank announcements. Furthermore, the ZLB episode was relatively short for Canada and thus the number of monetary policy events is limited. As a result, we are cautious in interpreting our results and treat the event study as a consistency check rather than a careful empirical exercise.

The Bank of Canada made several announcements during the ZLB period, three of which were particularly important: the announcement that the short rate was being lowered to 25 bps and would remain there until the second quarter of 2010 (April 21, 2009), the announcement that the Bank of Canada's conditional commitment to the ZLB was being removed (April 20, 2010), and the announcement that the short rate was being raised to $50 \mathrm{bps}$ (June 1, 2010). We include several other announcements in our event study that relate to the Bank of Canada's extraordinary liquidity operations during the ZLB, but we suspect, a priori, that these events may have a lesser impact on the shadow rate than the others as they were less widely reported or known outside of the traditional banking sector.

First, we look at the one-day changes in the shadow rate on announcement dates and identify whether they can be classified as tail events. We define a tail event as a statistically significant change in the shadow rate based on standard errors calculated assuming a normal distribu-

\footnotetext{
${ }^{10}$ In their paper, Wu and Xia (2016) show that there was no substantive difference in the response of US macroeconomic variables to the US shadow rate at and away from the ZLB. We do no repeat that exercise here.
} 
Figure 1. Canadian and US Policy Rates 1994-2016

(a)Canadian Policy Rate

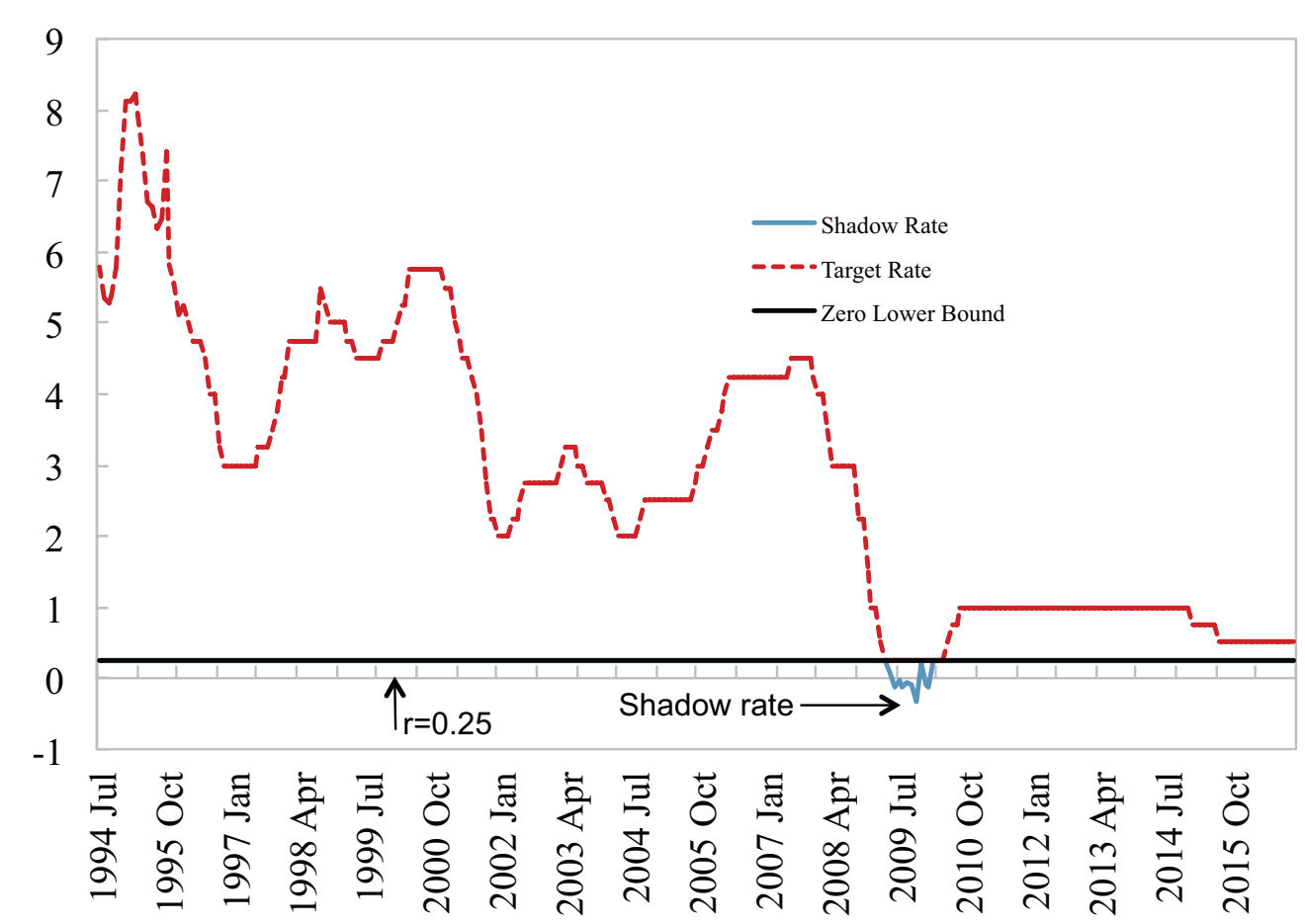

(b)US Policy Rate

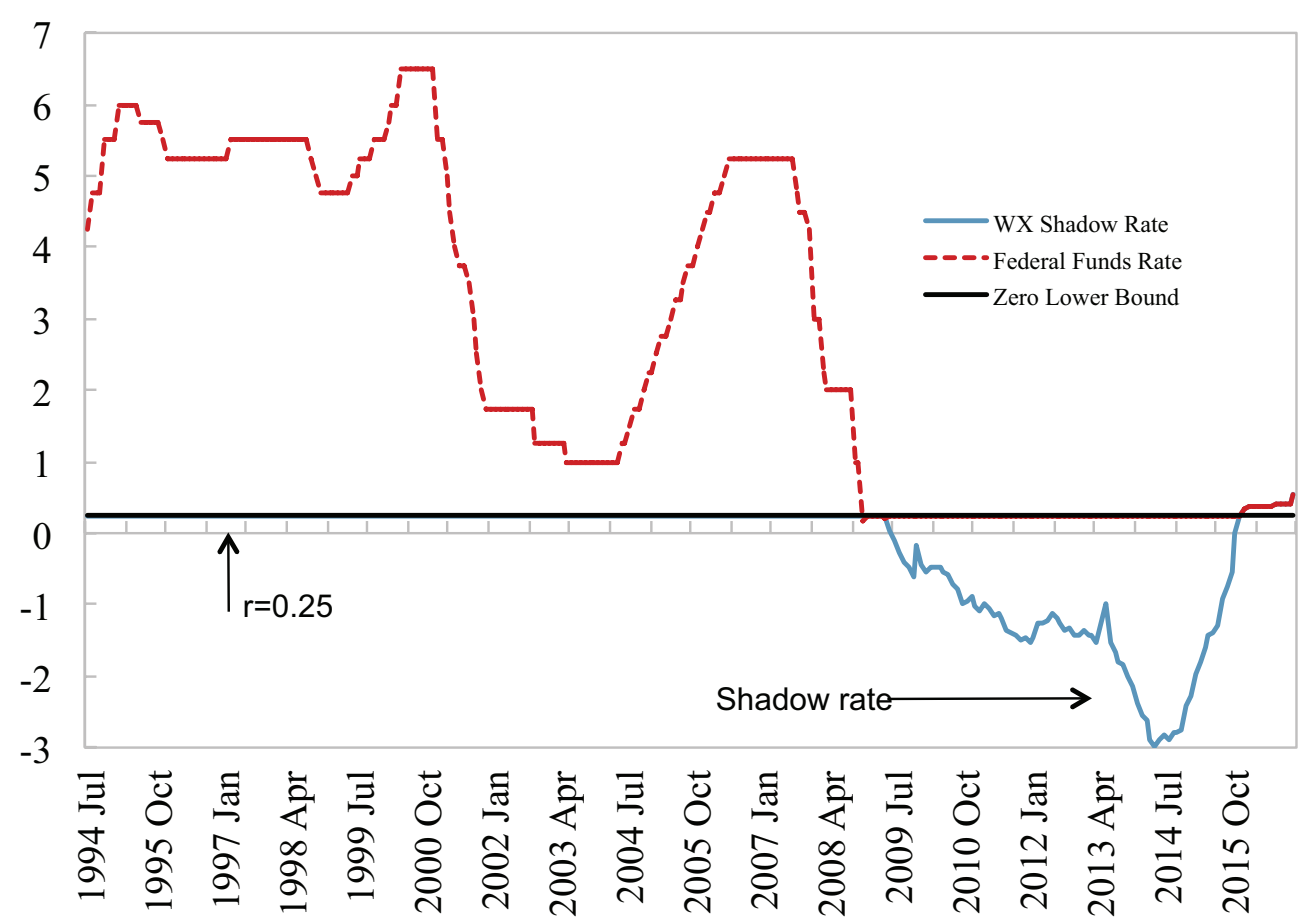

Note: The federal funds rate is the target federal funds rate before November 2008 and the upper bound of the federal funds rate from November 2008 onwards.

Source: FRED, Statistics Canada CANSIM, Bank of Canada, Wu and Xia (2016), and authors' own calculations. 
Table 1. Bank of Canada announcements and shadow short rate changes

\begin{tabular}{|c|c|c|}
\hline Date & $\Delta s r_{t}$ & Event Description \\
\hline April 21, 2009 & $-0.0964^{* * *}$ & $\begin{array}{l}\text { BoC announces operating framework for the implementation of monetary policy at the effective } \\
\text { lower bound for the target rate, lowers target rate target to } 1 / 4 \text { percent, introduces conditional } \\
\text { commitment to hold current policy rate until the end of the second quarter of } 2010 \text { and announces } \\
\text { term PRA transaction schedule. }\end{array}$ \\
\hline April 24, 2009 & -0.0408 & $\begin{array}{l}\text { BoC announces term PRA, term PRA for private sector instruments, and term loan facility (TLF) } \\
\text { transaction schedules. }\end{array}$ \\
\hline June 25,2009 & -0.0097 & $\begin{array}{l}\text { BoC announces extension of TLF and expanded swap facility with the Fed as well as temporary } \\
\text { reciprocal currency arrangements (swap lines) between the Fed and other central banks extended } \\
\text { to } 1 \text { February } 2010 \text {. }\end{array}$ \\
\hline July 21, 2009 & -0.0014 & $\begin{array}{l}\text { BoC announces term PRA, term PRA for private sector instruments, and TLF transaction sched- } \\
\text { ules. }\end{array}$ \\
\hline September $232009^{\dagger}$ & -0.0124 & $\begin{array}{l}\text { Reflecting the improved conditions in funding markets the BoC announced term PRA Facility } \\
\text { for private sector instruments (after a final operation on October 27, 2009) and TLF (after a final } \\
\text { operation on October 28, 2009) will expire at the end of October 2009. }\end{array}$ \\
\hline October 20, 2009 & $-0.0914^{* * *}$ & BoC announces another term PRA transaction schedule. \\
\hline November $6,2009^{\dagger}$ & -0.0056 & $\begin{array}{l}\text { Given improved conditions in funding markets the BoC announces that the temporary measure } \\
\text { allowing LVTS participants to assign their non-mortgage loan portfolios as eligible collateral } \\
\text { for LVTS and SLF purposes will be gradually reduced from } 100 \text { per cent to } 20 \text { per cent of each } \\
\text { participant's total pledged collateral starting starting February } 2,2010 \text {. }\end{array}$ \\
\hline December $16,2009^{\dagger}$ & 0.0282 & $\begin{array}{l}\text { Given improved conditions in funding markets the BoC announces term PRA operations will be } \\
\text { held on a monthly basis rather than bi-weekly, and that only Canadian dollar securities eligible } \\
\text { as collateral under the BoC's SLF will be eligible for term PRAs effective January } 19,2010 \text {. } \\
\text { Affiliated-dealer bank-sponsored ABCP, and BBB corporate bonds will no longer be eligible. }\end{array}$ \\
\hline April 20, 2010 & $0.1110^{* * *}$ & BoC maintains target rate at $1 / 4$ per cent and removes conditional commitment. \\
\hline May $10,2010^{\dagger}$ & $0.0873^{* *}$ & $\begin{array}{l}\text { BoC and the Fed reestablish US } \$ 30 \text { billion swap facility (reciprocal currency arrangement) that } \\
\text { had expired on February } 1,2010 .\end{array}$ \\
\hline June 1, 2010 & -0.0478 & $\begin{array}{l}\text { BoC increases target rate to } 1 / 2 \text { per cent and reestablishes normal functioning of the overnight } \\
\text { market as well as the standard operating framework for the implementation of monetary policy. } \\
\text { The target for the target rate is set to the midpoint of the operating band and the width of the } \\
\text { operating band to } 50 \text { bps. }\end{array}$ \\
\hline
\end{tabular}

Note: This table contains a list of major policy events and the corresponding changes in the shadow rate. *,**, and *** represent tail events with respect to a normal distribution at the standard 10,5, and 1 percent confidence levels. $\dagger$ marks announcement dates that were made the day before but after markets closed.

tion (following Bowman, Londono, and Sapriza, 2015). On several occasions the Bank of Canada made their announcements late in the day, either near to or after financial market closing. In these cases we look at the next-day change in the shadow rate for our analysis. The dates, event descriptions and one-day changes in the shadow short rate are reported in Table 1. We see that two of the three main ZLB announcements by the Bank of Canada were associated with tail events in changes in the shadow short rate - the 21 April 2009 announcement of the shift to the ZLB and the 20 April 2010 removal of conditional commitment. The announcement of exit from the ZLB on 1 June 2010 was not associated with a significant shift 
Table 2. Effect of Bank of Canada Announcements on Shadow Short Rate

\begin{tabular}{lll}
\hline Dependent Variable: $\Delta s r_{t}$ & & \\
& $(1)$ & $(2)$ \\
\hline Expansionary Announcement & $-0.025^{*}$ & -0.019 \\
& $(0.01)$ & $(0.02)$ \\
Contractionary Announcement & 0.015 & 0.020 \\
& $(0.02)$ & $(0.02)$ \\
FAD & & -0.014 \\
& & $(0.01)$ \\
MPR & & 0.002 \\
& & $(0.02)$ \\
\hline F-test & 0.12 & 0.17 \\
N & 280 & 280 \\
$R^{2}$ & 0.02 & 0.02 \\
\hline
\end{tabular}

Note: Standard errors in parentheses. Data frequency is daily. Period is April 20, 2009- June 1, 2010, which corresponds to the Canadian ZLB period (when the Bank of Canada Bank Rate was 25 basis points). Expansionary announcements include all PRA announcements, TLF announcements, and SLF announcements. Contractionary announcements include announcements regarding the end or reduction of the PRA, TLF, or SLF operations. FAD and MPR dummy variables are equal to one on dates that the Bank of Canada released FAD document or the MPR. F-test reports the test for null hypothesis that both the expansionary and contractionary announcement coefficients are jointly equal to zero.

in the ZLB, we suspect because after the removal of conditional commitment, further monetary tightening was widely expected.

We also estimate an event study regression to verify the robustness of the results. We regress the daily change in the estimated shadow rate on dummy variables for expansionary and contractionary announcements. Results are reported in Table 2, column (1). As expected, we see that expansionary announcements were associated with a fall in the shadow rate (significant at the 10 percent level) and contractionary announcements were associated with a rise (albeit not statistically significant). The signs on the coefficient estimates are robust to including dummy variables for the Bank of Canada's fixed announcement dates (FADs) and monetary policy report releases (MPR), reported in column (2), though no longer statistically significant. These are included to control for market reaction on anticipated announcement days.

Although the regression results lack significance, by virtue of the limited number of observations during the short Canadian ZLB period, they also do not produce any significant counterintuitive effects. Indeed, both the magnitude and direction of the change in the shadow rate in response to policy announcements are consistent with the behaviour of the Bank rate during conventional times. Therefore, we proceed with our empirical analysis and use the shadow rate as our policy indicator during the ZLB. 


\section{SMALL OPEN ECONOMY B-SVAR MODEL}

We model the dynamic interaction of the variables in the two countries using the SVAR:

$$
A Y_{t}=C+\sum_{l=1}^{p} B_{l} Y_{t-l}+\varepsilon_{t}
$$

where $Y_{t}$ is an $n \times 1$ vector of endogenous variables, $A$ and $B_{l}$ are $n \times n$ parameter matrices, $\varepsilon_{t}$ is an $n \times 1$ vector of structural shocks with $E\left(\varepsilon_{t} \mid Y_{1}, \ldots, Y_{t-1}\right)=0$ and $E\left(\varepsilon_{t} \varepsilon_{t}^{\prime} \mid Y_{1}, \ldots, Y_{t-1}\right)=I_{n}$.

We impose the small open economy assumption that Canada cannot influence US variables via block exogeneity restrictions on the parameters $A$ and $B_{l}$. This greatly reduces the number of parameters to be estimated despite the number of overall parameters increasing with the inclusion of US variables, which are meant to capture international influence on Canadian variables. We follow Cushman and Zha (1997) and assume that the endogenous variable vector $Y_{t}$ comprises two blocks: a Canadian block $Y_{t}^{\mathrm{CAN}}$ and a US block $Y_{t}^{\mathrm{US}}$. We allow the Canadian block to respond to the US variables both contemporaneously and with a lag, but restrict the US block to be self contained and not influenced by the dynamics in the Canadian variables. Specifically, we impose the restrictions in the following way

$$
\left[\begin{array}{cc}
A_{11} & A_{12} \\
0 & A_{22}
\end{array}\right]\left[\begin{array}{l}
Y_{t}^{\mathrm{CAN}} \\
Y_{t}^{\mathrm{US}}
\end{array}\right]=\left[\begin{array}{cc}
F_{11} & F_{12} \\
0 & F_{22}
\end{array}\right]\left[\begin{array}{l}
Z_{t}^{\mathrm{CAN}} \\
Z_{t}^{\mathrm{US}}
\end{array}\right]+\left[\begin{array}{l}
\varepsilon_{t}^{\mathrm{CAN}} \\
\varepsilon_{t}^{\mathrm{US}}
\end{array}\right],
$$

where $F=\left[C, B_{1}, \ldots, B_{p}\right]$ and $Z_{t}^{i}=\left[I, Y_{t-1}^{i}, \ldots, Y_{t-p}^{i}\right]^{\prime}$ for $i=\{\mathrm{CAN}, \mathrm{US}\}$.

For the Canadian block, our main specification includes the Canadian policy rate, $r$; the Canadian/US dollar exchange rate, $s$; seasonally-adjusted real Canadian industrial production, $y$; the Canadian consumer price index, $p$; seasonally adjusted Canadian exports $e x$, and seasonally adjusted Canadian imports, $\mathrm{im}$. We calculate net exports post-estimation. For the US block, we include the US policy rate $r^{*}$; the implied volatility of the S\&P 500 index, VIX; commodity export prices, $w p x$; the US consumer price index, $p^{*}$; and seasonally-adjusted real US industrial production, $y^{*}$. Detailed data definition and sources are provided in Table 7 of Appendix A. All variables are in logs except for the two policy rates, which we construct using (1), i.e. splicing the Bank of Canada target rate and the federal funds rate with their respective shadow rates whenever the shadow rates are below 25 bps (the ZLB). The Canadian shadow rate is calculated as described in Section II.A, using zero coupon bond yield curve data published by the Bank of Canada. ${ }^{11}$ We take the US shadow rate directly from Wu and

\footnotetext{
${ }^{11}$ See Bolder, Johnson, and Metzler (2004). Data is available at http://www.bankofcanada.ca/rates/interestrates/bond-yield-curves/.
} 
Xia (2016). Using the policy rate, as defined in (1), allows us to extend the data much farther and treat both central banks as if they have a constant reaction function but a varying set of policy instruments at the ZLB. It also allows us to conduct counterfactual exercises when the policy rate is at the ZLB. Including multiple business cycles gives our estimates more precision. The data is monthly from August 1994 to December 2016. The beginning of our sample coincides with a shift in the Bank of Canada's operating procedure as it adopted a $50 \mathrm{bps}$ operating band around the target rate and shifted to targeting the overnight rate as its key monetary policy instrument. This change was part of a broader transition in the 1990s to targeting two percent inflation and improving both the clarity and efficiency of monetary policy.

Our identification is based on exclusion restrictions in the contemporaneous coefficient matrix $A$. We assume that the Bank of Canada reacts contemporaneously to the exchange rate, the US policy rate, the VIX and commodity prices. Including commodity prices is particularly important for decision making by the Bank of Canada for two reasons. First, commodity prices adjust very quickly to market conditions and hence they control for future price expectations, i.e. they help mitigate the price puzzle often found in similar SVAR analyses, and second, since Canada is a commodity exporter, commodity prices have a large impact on Canadian output as well as on the value of the Canadian dollar. Following Gambacorta, Hofmann, and Peersman (2014), we include the VIX as a proxy for financial turmoil, economic risk, and uncertainty, which played a critical role in the latter part of our sample. We control for imports and exports to capture real spillovers between Canada and the US. We let the exchange rate react contemporaneously to all variables, domestic and foreign, in the model and assume that the production sector of the Canadian economy takes an upper triangular form with the variables ordered $(p, y, i m, e x)$. We assume the US block takes an upper triangular form, ordered $\left(r^{*}, V I X, \operatorname{wxp}, p^{*}, y^{*}\right)$, so that industrial production and prices cannot respond to a monetary policy shock within the same month. ${ }^{12}$

The total number of restrictions on the contemporaneous coefficient matrix is 111 . However, since we need only $n(n-1) / 2=55$ restrictions for exact identification, the model is overidentified. Although overidentification permits a more sensible set of restrictions than a recursive ordering, it imposes restrictions on the reduced-form covariance matrix, $A^{-1} A^{-1^{\prime}}=\Omega$, which complicates the estimation. The posterior distribution of $\Omega$ does not have a convenient form and regular Monte Carlo integration methods cannot be used. To overcome this, we follow the Waggoner and Zha (2003) Gibbs sampler method with 5000 draws, discarding the first 1000 to ensure that the initial values do not affect the posterior distribution. We use the Sims

\footnotetext{
${ }^{12}$ Because we are interested only in responses to unexpected monetary policy shocks, the ordering of the remaining variables in the US block is immaterial.
} 
and Zha (1998) prior and set loose values for all hyper-parameters except for the lag decay: $\mu_{i}=10$ for $i=1, \ldots, 6$. We estimate the model with 12 lags and report 68 percent error bands as well as the means of the posterior distribution.

Prior to estimation, we check the validity of the overidentifying restrictions. Since the contemporaneous coefficient matrix is overidentified, we cannot directly test block exogeneity in the reduced form VAR. Similarly, we cannot directly test overidentifying restrictions because of block exogeneity imposed in the contemporaneous coefficient matrix. Instead, we follow Cushman and Zha $(1995,1997)$ and perform a joint likelihood ratio test for overidentification and block exogeneity in the contemporaneous coefficient matrix and block exogeneity in the lagged coefficient matrices (a total of 385 restrictions). This test fails to reject the null hypothesis of block exogeneity, and we proceed on the basis that our assumption of block exogenity is valid. ${ }^{13}$

\section{RESULTS}

\section{A. Monetary Policy Shocks}

We first consider the dynamic response of the variables in our system to both domestic and foreign expansionary monetary policy shocks and then use the estimated system to perform counterfactual experiments based on the historical decomposition. In all cases we report the mean, the 68 percent confidence bands which are common in the literature and represent one standard deviation from the mean, and the 90 percent confidence bands which imposes more stringent criteria on our results.

The impulse response functions from a 25 bps expansionary shock to Canadian monetary policy are shown in Figure 2. Prices, industrial production, and the exchange rate respond to this shock in accordance with theoretical models and existing empirical evidence. That is, an expansionary monetary policy shock raises industrial production and prices significantly on impact, and for approximately 18 to 24 months after the initial shock. The currency depreciates on impact, and for about one year after the shock (statistically significant at the 68 percent level). Along with this slightly weaker Canadian dollar we see a significant, albeit temporary, rise in exports about 6 months after the initial shock. We also see a significant (and temporary) rise in imports, which implies an income effect stemming from the rise in industrial production. Post-estimation we calculate the impulse response of net exports, which shows

\footnotetext{
${ }^{13}$ The likelihood-ratio test statistic is 419.01 and the 5 percent critical value is 431.75
} 
Figure 2. Impulse Response Functions: Canadian Monetary Policy Shock

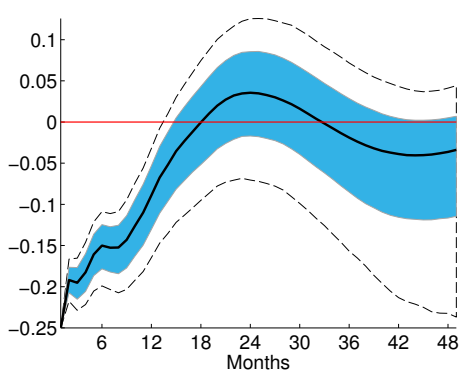

(a) Interest rate

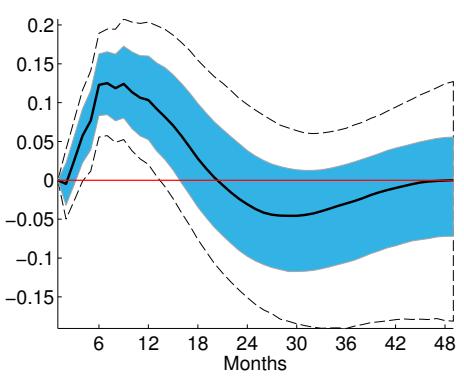

(d)Industrial Production

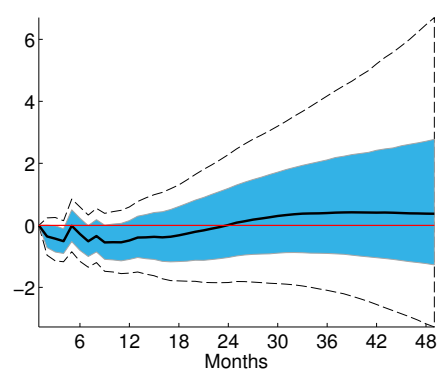

(g)Net Exports

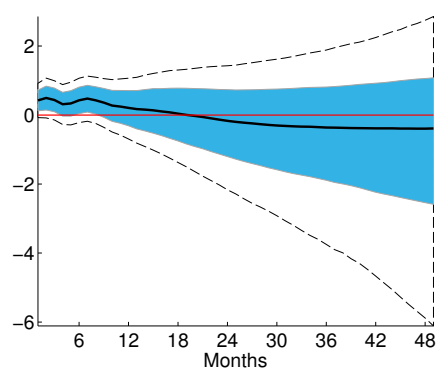

(b)Exchange rate

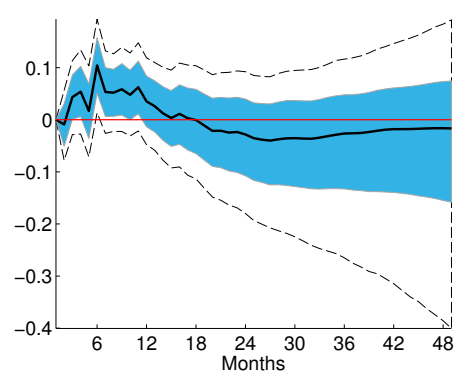

(e)Imports

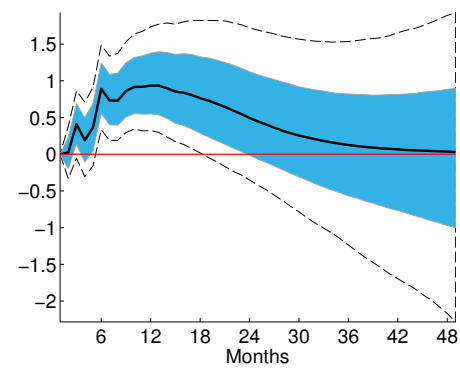

(c)Price Level

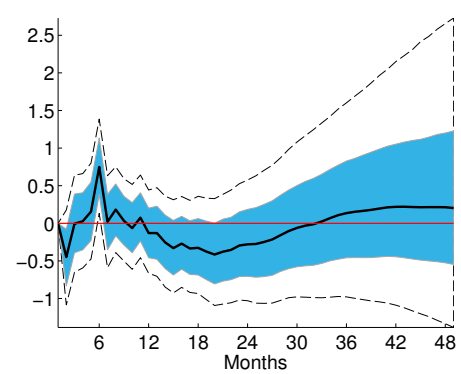

(f)Exports

Note: Impulse response functions for the Canadian variables in response to a 25 bps expansionary Canadian monetary policy shock. Error bands are constructed based on 5000 Gibbs sampling draws from the posterior distribution. The blue shaded area represents the 68 percent error band, the dashed line represents the 90 percent error band. Net exports are calculated ex-post estimation, not included in the estimated model.

that the income effect of the rise in industrial production outweighs the currency effect (albeit only marginally negative and significant at the 68 percent level).

The impulse response functions from a 25 bps expansionary shock to US monetary policy are shown in Figure 3. Though our primary focus is on the impact to Canadian variables, we also report the response of US variables in figures $3 \mathrm{a}-3 \mathrm{e}$, showing that these are gener- 
Figure 3. Impulse Response Functions: US Monetary Policy Shock

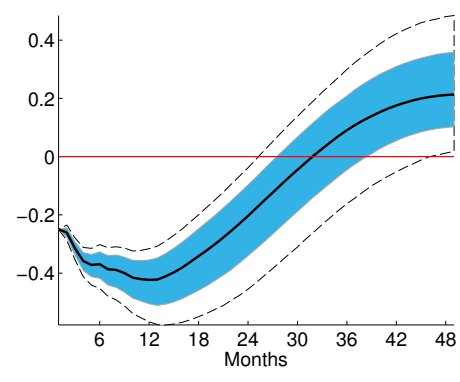

(a)Interest Rate (US)

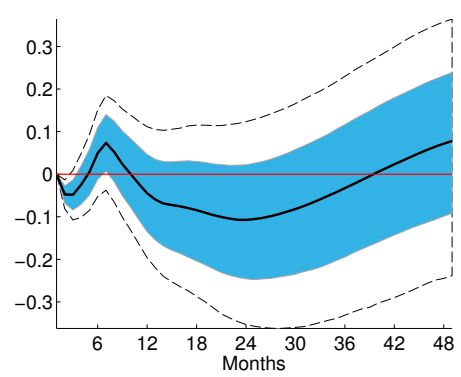

(d)Price Level (US)

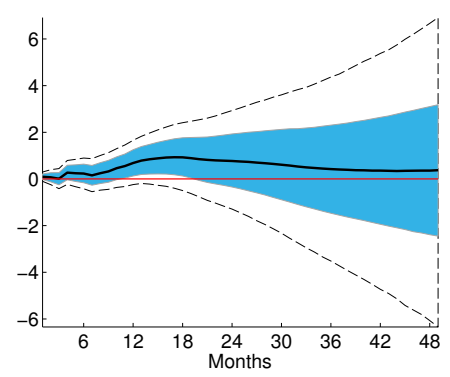

(g)Exchange rate

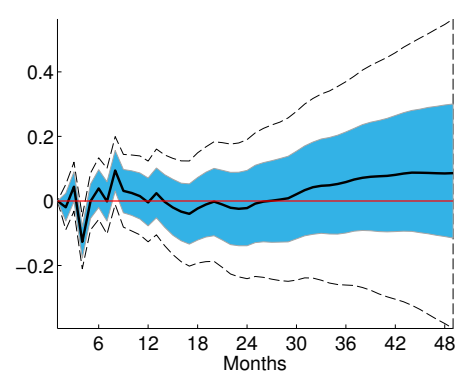

(j)Imports (CA)

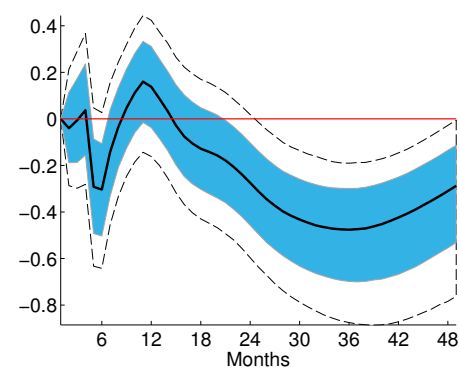

(b) VIX

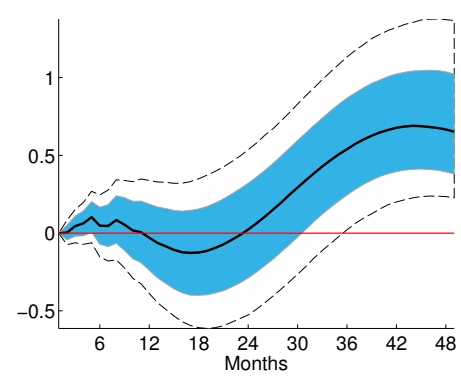

(e)Industrial Production (US)

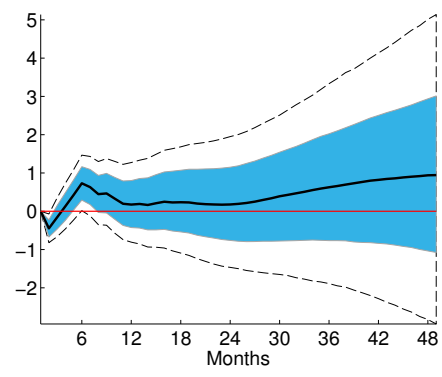

(h)Price Level (CA)

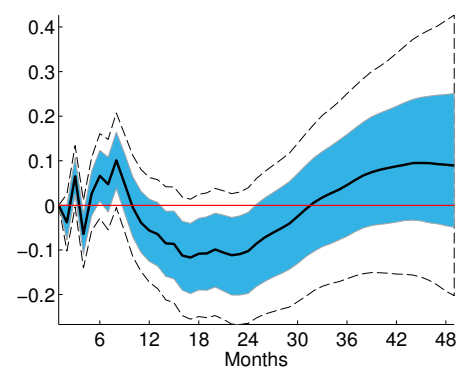

(k)Exports (CA)

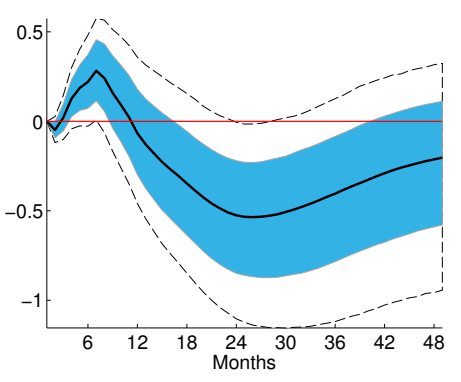

(c)Commodity prices

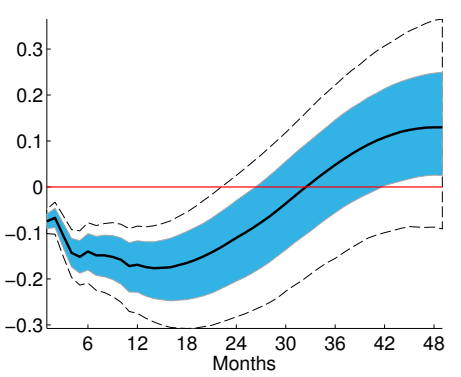

(f)Interest Rate (CA)

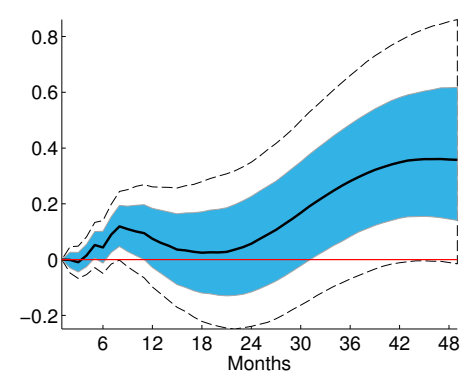

(i)Industrial Production (CA)

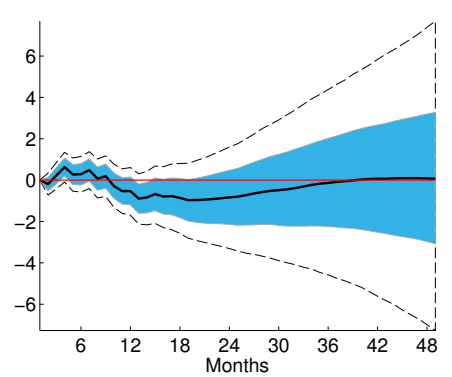

(1)Net Exports (CA)

Note: This figure contains the impulse response functions for the all variables in response to a 25 bps expansionary US monetary policy shock. Error bands are constructed based on 5000 Gibbs sampling draws from the posterior distribution. The blue shaded area represents the 68 percent error band, the dashed line represents the 90 percent error band. Net exports are calculated ex-post estimation, not included in the estimated model. 
ally consistent with theoretical and empirical literature. ${ }^{14}$ Following the US monetary policy shock industrial production rises significantly with a delay of approximately 1-2 years. Though prices fall significantly on impact (this price puzzle is commonly found in the recursive SVAR literature), they rise slightly after about 6 months for a short period. Commodity prices rise on impact, consistent with literature that has found expansionary policy raises these prices through expectations (of inflation and growth) channels and demand and supply channels based on the cost of carrying inventories and extracting goods (Anzuini, Lombardi, and Pagano (2013)). US equity market volatility falls significantly, also consistent with empirical literature that has shown loose monetary policy dampens risk aversion and uncertainty (Bekaert, Hoerova, and Lo Duca (2013) and Bruno and Shin (2015)).

Figure $3 \mathrm{f}$ shows a response from the Canadian policy rate both on impact and for over two years following the initial shock, demonstrating the substantive spillover from US policy rates to the Canadian economy. Following domestic monetary contraction, the Canadian dollar depreciates (Figure 3g), and both the policy rate and exchange rate reach a minimum after about 18 months. Canadian industrial production (Figure 3i) rises after about 6 months in response to the US monetary policy shock and then again following the same delay as US industrial production (significant at 68 percent confidence levels). As in the US, Canadian prices fall in the first month and then rise after about 5 months. Both impulse responses reiterate the strong spillover from US monetary policy on real Canadian variables. ${ }^{15}$ On a net basis, exports rise initially then fall temporarily after about a year, which indicates alternating exchange rate and income effects on Canadian trade.

We draw two conclusions from these impulse response functions: first, that a Canadian expansionary monetary policy shock boosts domestic prices and industrial production, and depreciates the Canadian dollar. This provides support for our model, and for the use of the shadow rate as our policy variable, as the impulse response functions are generally consistent with other pre-global financial crisis empirical studies and theoretical literature on the impact of monetary policy shocks. Second, the results show that while a US expansionary monetary policy shock increases US industrial production, as expected, it also has cross border effects on the Canadian economy. These spillovers operate through the exchange rate channel, through the endogenous response of the Bank of Canada's policy rate, and through spillovers to real variables.

\footnotetext{
${ }^{14}$ The impact on the US economy has been studied extensively, as discussed in section I. We have not attempted to model the US economy explicitly here, but rather included those US variables which have been showed to be important for Canadian spillovers.

${ }^{15}$ Results are all statistically significant at the 68 percent level.
} 


\section{B. Effects of unconventional monetary policy}

In order to quantify the effects of unconventional monetary policy we conduct a counterfactual experiment similar to $\mathrm{Wu}$ and Xia (2016), where we simulate a scenario in which the shadow rate remains at 25 bps (the ZLB) while the other variables remain unrestricted. We assume that, since the nominal rate is bounded by $25 \mathrm{bps}$, any movement in the policy rate below this bound is driven by unconventional monetary policies. As a result, we interpret our estimates as an upper bound on the effect of unconventional monetary policy.

We begin with a historical decomposition of our model, which decomposes each variable in $Y_{t}$ into the contributions from their initial value, their constant term, and their structural shocks:

$$
Y_{t}=\underbrace{G^{t} Y_{0}}_{\text {initial condition }}+\underbrace{\sum_{i=1}^{t} G^{i} C}_{\text {constant }}+\underbrace{\sum_{i=1}^{t} \Psi_{i-1} \varepsilon_{t-i+1}}_{\text {structural shocks }},
$$

where $G=A^{-1} F$ and $\Psi_{i}$ is the set of coefficients for the impulse response function in period $i$. We use this equation to calculate the paths of the variables under different scenarios by manipulating the set of contributing structural shocks. The scenarios we are interested in are those that restrict the Canadian and US shadow rate to $25 \mathrm{bps}$. That is, we want to see the counterfactual paths of variables in our model had the Bank of Canada and Fed not engaged in any unconventional policies.

For Canada, the counterfactual is implemented by replacing the realized monetary policy shock, $\varepsilon_{t}^{M P_{C A N}}$ in (2), with a counterfactual shock, $\tilde{\varepsilon}_{t}^{M P_{C A N}}$, such that the shadow rate respects the lower bound, $\tilde{s_{t}}=0.25$ when the actual target rate was at $25 \mathrm{bps}$. Similarly for the US, the counterfactual is implemented by replacing replace $\varepsilon_{t}^{M P_{U S}}$ in (2) with $\tilde{\varepsilon}_{t}^{M P_{U S}}$, such that $\tilde{s}_{t}^{*}=0.25$ when the federal funds rate was at the ZLB. ${ }^{16}$ The path of each variable is then simulated under these two scenarios.

\section{Restricted monetary policy in Canada}

Figure 4 reports the results for our first experiment which restricts Canadian unconventional monetary policy. We show each original series with its counterfactual path, which we inter-

\footnotetext{
${ }^{16}$ We have also conducted a third counterfactual experiment that replaces both the Canadian and US monetary policy shocks with counterfactual shocks so as to make both the Canadian and US shadow rates constrained at $\tilde{s}_{t}=\tilde{s}_{t}^{*}=0.25$. Because the impact of US unconventional monetary policy is so large relative to Canadian unconventional policy (as reported in this section), the results from this experiment are essentially unchanged from the US counterfactual experiment. We thus do not report these results here, but note that they are available upon request.
} 
pret as (an upper bound of) what the state of the economy would have been had the Bank of Canada not provided any additional stimulus beyond lowering the target rate to $25 \mathrm{bps}$.

Figure 4. Counterfactual Paths: Canadian ZLB Imposed

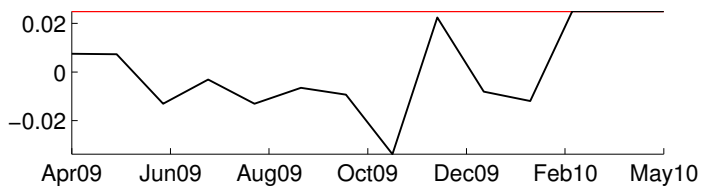

(a)Interest rate

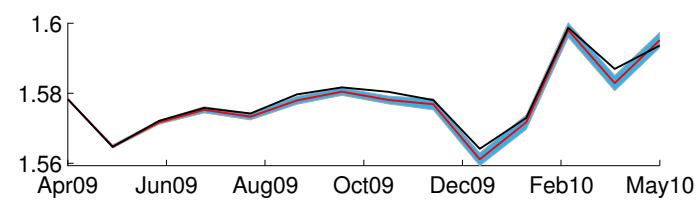

(c)Imports

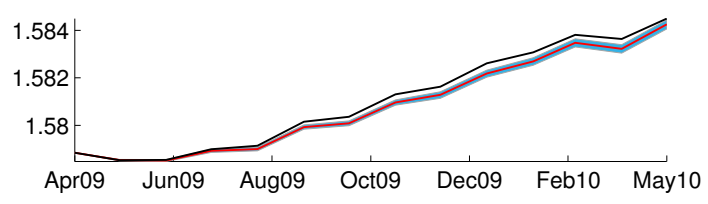

(e)Industrial Production

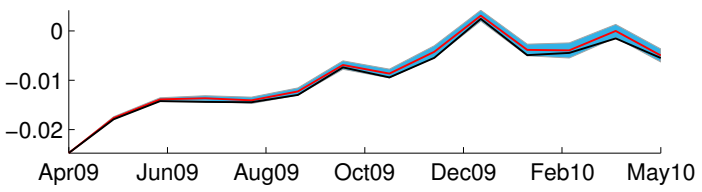

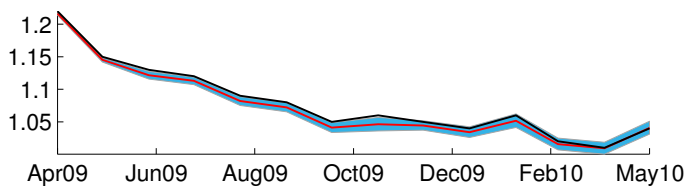

(b)Exchange rate

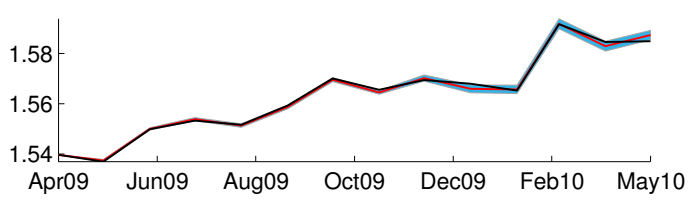

(d)Exports

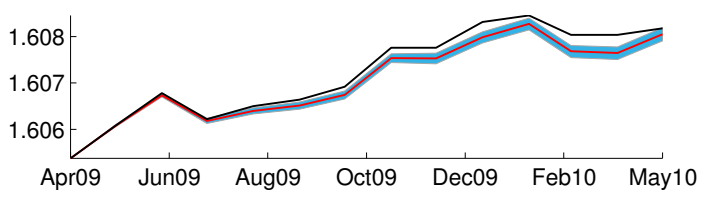

(f)Price Level

(g)Net Exports

Note: This figure plots the observe value of each series in our model along with an estimate of its counterfactual path, which is constructed by generating a set of structural shocks for the policy rate such that the policy rate is forced to respect the ZLB (25 bps). Error bands are constructed based on 5000 Gibbs sampling draws from the posterior distribution and reported at the 68 percent level. The red line is the counterfactual value, blue band is the error band, and the black line is the real observed value. Net exports are calculated ex-post estimation, not included in the estimated model.

Figure 4a visually demonstrates how the counterfactual scenario is constructed: while the shadow rate was below 25 bps from 2009-2010, we restrict the policy rate in our experiment to be bound by $25 \mathrm{bps}$, the red line represents this counterfactual path. Figure $4 \mathrm{e}$ (which is zoomed-in to the ZLB period only) shows that under the counterfactual scenario Canadian industrial production would have been significantly lower than its observed value. Table 3 con- 
tains the average percentage difference between each observed series and its counterfactual paths during the ZLB period, along with the 68 percent confidence band of this estimate. ${ }^{17}$ Industrial production and prices would have been 0.013 percent and 0.008 percent lower on average during the Canadian ZLB period, respectively, had the Bank of Canada been unable to provide any additional stimulus (with both values significantly different than zero on average through the entire period, based on 68 percent confidence bands). Over the entire ZLB period, industrial production and prices would have been cumulatively 0.14 and 0.09 percent lower, respectively. While the brevity of the ZLB period in Canada limits the extent to which unconventional monetary policy could affect the real economy and the magnitude of the counterfactual is accordingly modest, the counterfactual and observed paths are nonetheless significantly different from one another.

Importantly, although industrial production and prices are significantly lower under the counterfactual scenario, they would have returned to their observed path within two years, as can be seen at the end of their plots. This implies that unconventional monetary policy operations conducted by the Bank of Canada sped up the recovery of the Canadian economy significantly, but had relatively short term, or transitory, effects.

\section{Restricted monetary policy in the US}

Figure 5 reports the results from our second counterfactual experiment where we restrict the US shadow rate to 25 bps after December 2008, while the Federal Funds rate was at the ZLB. ${ }^{18}$ US unconventional monetary was significantly more expansionary than Canadian unconventional monetary policy and the ZLB episode lasted much longer (Figure 5a). The measured magnitude of the effects of US unconventional monetary policy is also much larger. US industrial production is substantially, and almost persistently, lower throughout the counterfactual experiment (Figure 5e). The trajectory of industrial production reveals that without unconventional intervention from the Fed, US industrial production would have significantly diverted from its growth path. The summary statistics from the counterfactual experiment indicate that US industrial production would have been 0.157 percent lower on average without the Fed's unconventional monetary policy (Table 3). This estimate is more conservative than previous studies: Dahlhaus, Hess, and Reza (2014) find that US GDP would have been 2.3 percent lower on average over the period from 2008Q4 to 2013Q3 if the Fed's balance sheet continued to grow at pre-crisis levels; Chung, Laforte, Reifschneider, and Williams (2012),

\footnotetext{
${ }^{17}$ Results hold with 90 percent confidence bands, which are displayed in Figure 19 and Table 8.

${ }^{18}$ Figure 20 presents results with 90 percent confidence bands.
} 
Figure 5. Counterfactual Paths: US ZLB Imposed

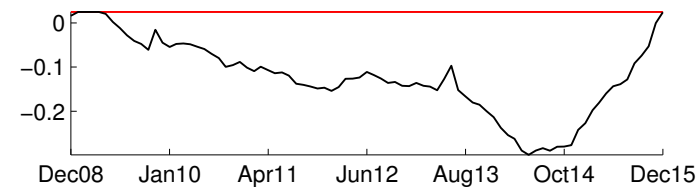

(a)Interest Rate (US)

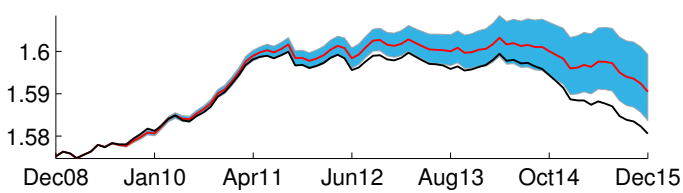

(c)Commodity prices

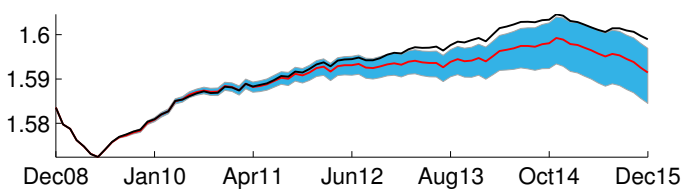

(e)Industrial production (US)

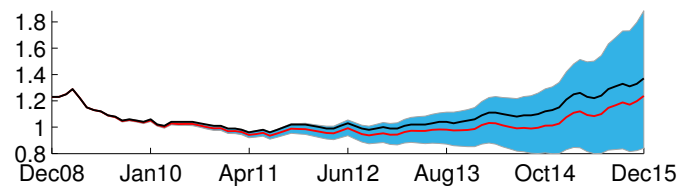

(g)Exchange rate

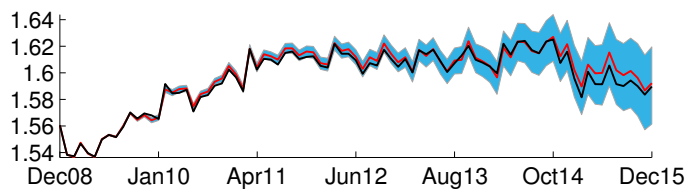

(i)Exports

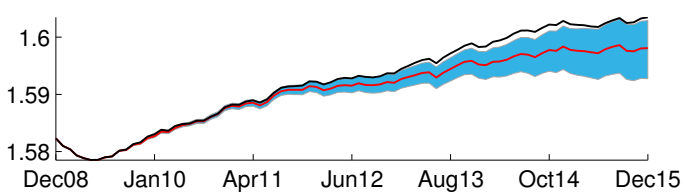

(k)Industrial production

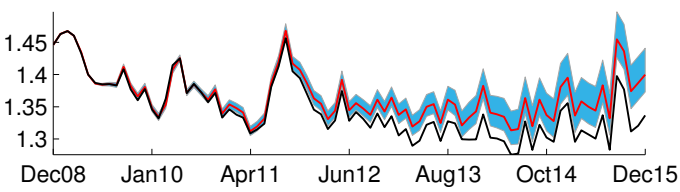

(b)VIX

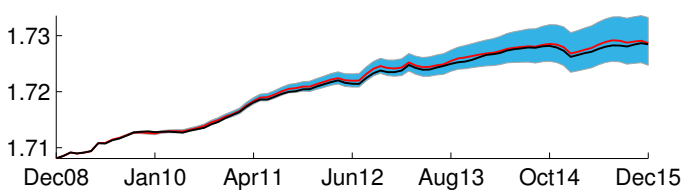

(d)Price Level (US)

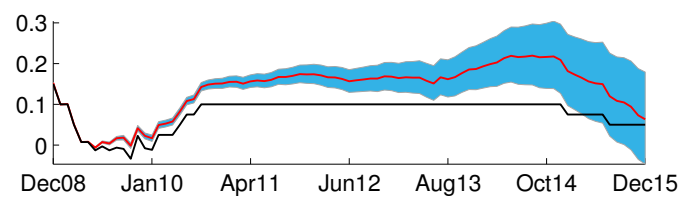

(f)Interest rate

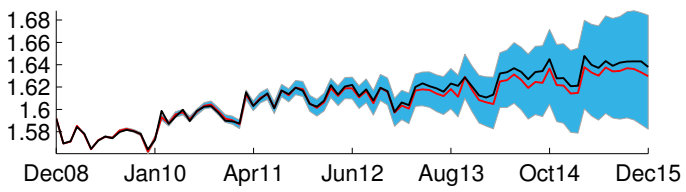

(h)Imports

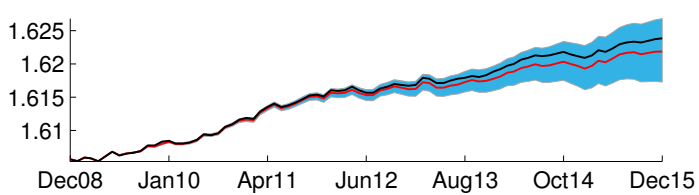

(j)Price Level

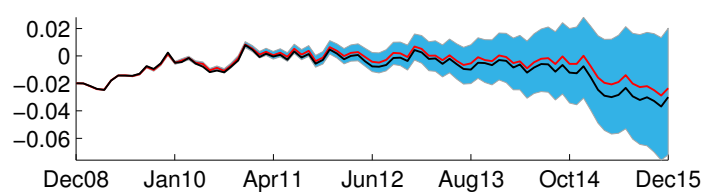

(1)Net Exports

Note: This figure plots the observe value of each series in our model along with an estimate of its counterfactual path, which is constructed by generating a set of structural shocks for the policy rate such that the policy rate is forced to respect the ZLB (25 bps). Error bands are constructed based on 5000 Gibbs sampling draws from the posterior distribution and reported at the 68 percent level. The red line is the counterfactual value, blue band is the error band, and the black line is the real observed value. Net exports are calculated ex-post estimation, not included in the estimated model. 
Table 3. Average Counterfactual Path for ZLB

\begin{tabular}{|c|c|c|c|c|c|c|}
\hline \multirow{3}{*}{ Variable } & \multicolumn{3}{|c|}{ Canadian ZLB Imposed } & \multicolumn{3}{|c|}{ US ZLB Imposed } \\
\hline & \multirow[t]{2}{*}{ Mean } & \multicolumn{2}{|c|}{$68 \%$ Conf. Bound } & \multirow[t]{2}{*}{ Mean } & \multicolumn{2}{|c|}{$68 \%$ Conf. Bound } \\
\hline & & Min & $\operatorname{Max}$ & & Min & Max \\
\hline & \multicolumn{6}{|c|}{ Percent Difference } \\
\hline Canadian interest rate & 0.031 & 0.031 & 0.031 & 0.063 & 0.025 & 0.105 \\
\hline Canadian CPI & -0.008 & -0.013 & -0.004 & -0.043 & -0.127 & 0.045 \\
\hline Canadian industrial production & -0.013 & -0.018 & -0.007 & -0.127 & -0.238 & -0.020 \\
\hline US interest rate & & & & 0.157 & 0.157 & 0.157 \\
\hline US CPI & & & & 0.021 & -0.068 & 0.118 \\
\hline \multirow[t]{2}{*}{ US industrial production } & & & & -0.157 & -0.333 & -0.007 \\
\hline & \multicolumn{6}{|c|}{ Cumulative Percent Difference } \\
\hline Canadian i & -0.140 & -0.240 & -0.042 & -10.14 & -26.03 & 4.77 \\
\hline \multirow[t]{2}{*}{ US industrial production } & & & & -12.54 & -39.04 & 7.26 \\
\hline & \multicolumn{6}{|c|}{ Unit Difference } \\
\hline Canadian interest rate & 1.000 & 1.000 & 1.000 & 0.557 & -1.000 & 2.333 \\
\hline Canadian CPI & -0.681 & -1.049 & -0.338 & -1.907 & -5.945 & 2.475 \\
\hline Canadian industrial production & -1.062 & -1.498 & -0.635 & -5.054 & -9.827 & -0.548 \\
\hline US interest rate & & & & 1.00 & 1.00 & 1.00 \\
\hline US CPI & & & & 0.254 & -3.134 & 4.149 \\
\hline \multirow[t]{2}{*}{ US industrial production } & & & & -6.817 & -13.535 & -1.668 \\
\hline & \multicolumn{6}{|c|}{ Cumulative Unit Difference } \\
\hline Canadian industrial production & $1-11.68$ & -19.81 & -3.82 & -404.3 & -106.9 & 249.76 \\
\hline US industrial production & & & & -545.4 & -1565.3 & 128.9 \\
\hline
\end{tabular}

Note: This table contains the average and cumulative percent (top panel) and average and cumulative unit (bottom panel) differences between the observed values and the counterfactual mean as well as $68 \%$ bounds. The average difference is calculated as $\frac{1}{\tilde{T}} \sum_{t \in Z L B} \frac{y_{t}-y_{t}^{C F}}{y_{t}}$ (percent difference) and $\frac{1}{\widetilde{T}} \sum_{t \in Z L B} y_{t}-y_{t}^{C F}$ (unit difference), where $y_{t}$ is $\mathrm{t}$ the observed value at time $t$ and $y_{t}^{C F}$ is the value under the counterfactual scenario, ZLB denotes the time period for the experiment and $\tilde{T}$ the number of observations for the experiment during the ZLB. Note that in those cases when the max and min bounds include 0 , the possibility that the paths were significantly different from zero for individual months during the experiment period is not excluded. The cumulative difference is calculated as $\sum_{t \in Z L B} \frac{y_{t}-y_{t}^{C F}}{y_{t}}$ (percent difference) and $\sum_{t \in Z L B} y_{t}-y_{t}^{C F}$ (unit difference).

find that US GDP would have been 3 percent lower in 2012 without the first instalment of quantitative easing (QE I); Baumeister and Benati (2013) find that QE I boosted US GDP growth by 2 percent in 2009; and Wu and Xia (2016) find that the US industrial production index would have been 0.79 percent lower in December 2013. In contrast to these studies we look at the entire sample period during which the US was at the ZLB, notably capturing the more recent years when the economy began recovering before the Fed raised rates, which may explain part of the difference. Cumulatively, the difference in industrial production from the observed path to the counterfactual is -12.54 percent over the ZLB period. 
Importantly, we find that US unconventional monetary policy had a significant impact on the Canadian economy. The Canadian policy rate would have been much higher under this counterfactual scenario, remaining at around 2 percent for much of the experiment (Figure 5f). The higher Canadian policy rate again highlights the sensitivity of the Bank of Canada's reaction function to movements in the US policy rate. Canadian industrial production clearly benefited from US expansionary policies (Figure 5k). Not only is it significantly lower un-

der the counterfactual scenario - about 0.117 percent lower on average (Table 3 ) and -10.14 percent cumulatively — but it would be on a different trajectory without US policy intervention. This estimate is also more conservative than the only other study that we are aware of that considers a similar question: Dahlhaus, Hess, and Reza (2014) find that US QE alone increased Canadian GDP by 2.2 percent on average over the period from 2008Q4 to 2013Q3.

The fundamental result from this US counterfactual experiment, which can be seen clearly in Figure 5, is that not only would Canadian industrial production have been lower on average during the US ZLB, but its trend would have been altered for a considerable length of time. Looking at the last period of our sample, December 2016, we estimate that Canadian industrial production would have been 0.34 percent lower than its observed value (this is the average estimated value, with the 68 percent confidence band (-0.66, -0.04)). Similarly, US industrial production would have been on a very different path for substantially longer without the Fed's actions, with the mean estimated industrial production 0.474 percent lower than observed at end-2016 (with the confidence band $(-0.874,-0.146)$ ). The more persistent effect of the Fed's unconventional monetary policy shocks stands in stark contrast to the Bank of Canada's.

\section{RobUSTNESS}

In order to determine whether our results are overestimated due to omitted variable bias, or misspecification, we conduct several robustness exercises. In Section V.A we control for government expenditure, which often plays a complimentary role to expansionary monetary policy. In Section V.B we replaced the shadow rate with an estimate Taylor Rule rate. In Section V.C we use the current account as an alternative to trade, to capture real spillovers between the US and Canada that include income flows and transfers. Finally, in Section V.D we proposed an alternate restriction specification to our original model. In all cases our results are robust to the different specifications. 


\section{A. Government expenditure}

Government stimulus can play an important role in economic recoveries, and it has been argued that this was particularly true in the aftermath of the 2007-09 financial crisis. Since monetary policy easing often coincides with expansionary fiscal policy, excluding a control for this variable could lead to overestimating the effect of monetary policy on industrial production (Rossi and Zubairy, 2011). In this section we adjust our main specification to control for fiscal policy, measured by federal government expenditures. Following the literature on government shocks (see e.g. Ramey, 2011, 2016), we assume that discretionary fiscal policy does not respond contemporaneously to any variable because of legislative delays. Based on this assumption we add to our original model: Canadian government discretionary spending, ordered last in the production block of the vector of Canadian variables, $Y_{t}^{\mathrm{CAN}}$; and US government discretionary spending, also ordering it last in the US block, $Y_{t}^{\mathrm{US}}$.

Figures 6 and 7 contain the impulse response functions, which are consistent with the main specification ${ }^{19}$. Following a Canadian expansionary shock, industrial production and prices rise, the Canadian dollar depreciates on impact, and interestingly government shows no significant change. In response to a US expansionary shock, Canadian and US industrial production rise significantly after a short delay. Canadian government spending rises initially, albeit insignificantly. US government spending, on the other hand, shows a significant increase in line with monetary stimulus.

The results of the counterfactual experiments, reported in Figures 8 and 9 and Table 4, are similar to the findings in the main specification. We estimate that Canadian industrial production would have been 0.012 percent lower on average during the ZLB without Canadian unconventional monetary policy. US industrial production would have been 0.098 percent lower on average during the ZLB period, and Canadian industrial production 0.137 percent lower on average without US unconventional monetary policy. These estimates and confidence bands are within the confidence bands reported in Table 3.

\footnotetext{
${ }^{19}$ Figures 21 and 22 of Appendix C present the same results showing only 68 percent confidence bands. This gives a better understanding of the shape of the impulses responses (see Sims and Zha (1999) for detailed explanation of this point), which are somewhat obscured with 90 percent confidence bands as they become very large after 2 years
} 
Figure 6. Impulse Response Functions: Canadian Monetary Policy Shock, Government Expenditure Model

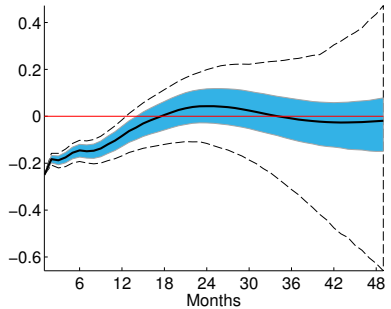

(a)Interest rate

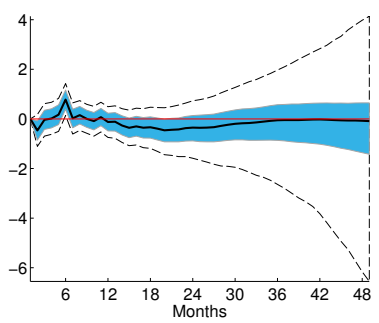

(d)Exports

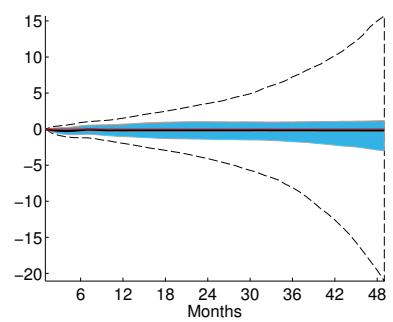

(g)Gov't expenditures

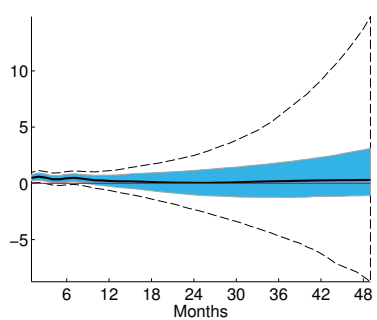

(b)Exchange rate

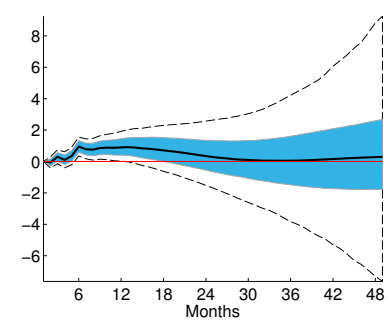

(e)Price Level

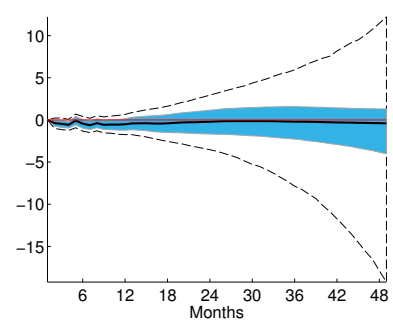

(h)Net Exports

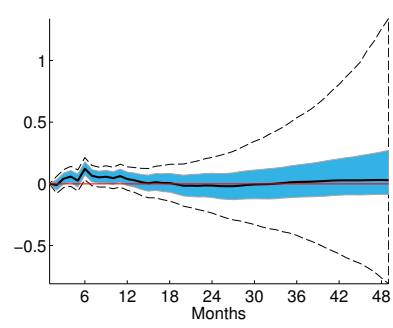

(c)Imports

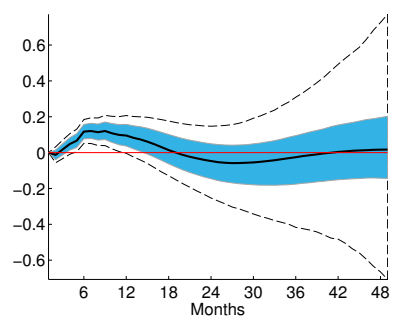

(f)Industrial production

Note: See figure 2.

\section{B. Using a Taylor Rule}

As a second robustness exercise, we use a derived Taylor Rule as our central bank policy rate in place of the shadow rate for both countries. The Taylor Rule, originally introduced in Taylor (1993) and Taylor (1999) is an alternative estimate of a policy rate which, like the shadow rate, is based on current economic conditions. In this case, it is based on the output gap and the rate of inflation. We derive the Taylor Rule using the prescribed Taylor Rule for the US generated by the Federal Reserve Bank's of Atlanta's Taylor Rule Utility, which calculates the rate based on the generalization of Taylor's formula:

$$
\widehat{F F R}_{t}=\rho F F R_{t-1}+(1-\rho)\left[\left(r_{t}^{*}+\pi_{t}^{*}\right)+1.5\left(\pi_{t}-\pi_{t}^{*}\right)+\beta g a p_{t}\right]
$$


Figure 7. Impulse Response Functions: US Monetary Policy Shock, Government Expenditure Model

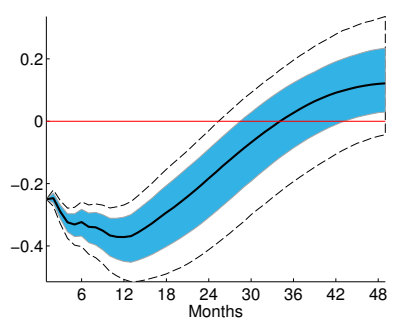

(a)Interest Rate (US)

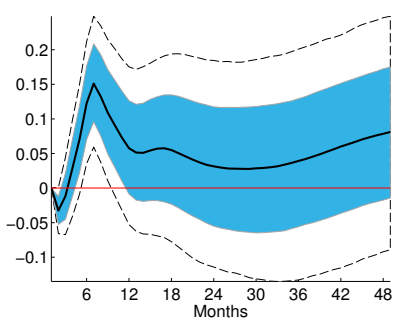

(d)Price Level (US)

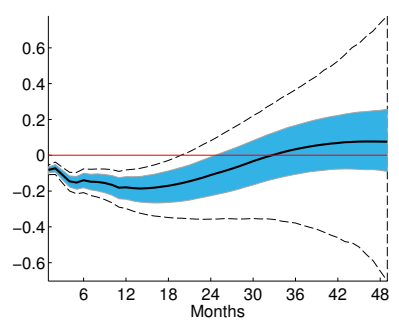

$(\mathrm{g})$ Interest rate $(\mathrm{CA})$

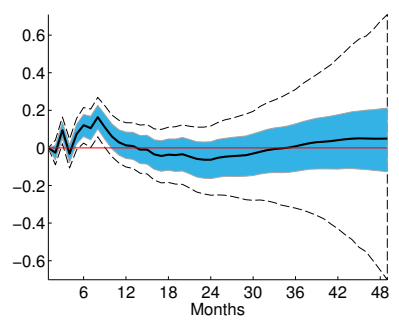

(j)Exports (CA)

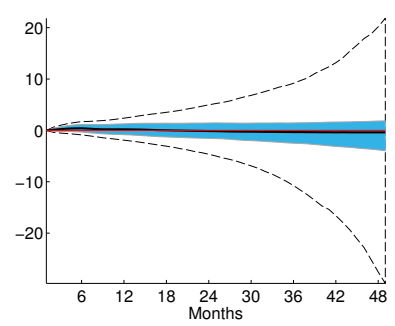

(m)Gov't expenditure (CA)

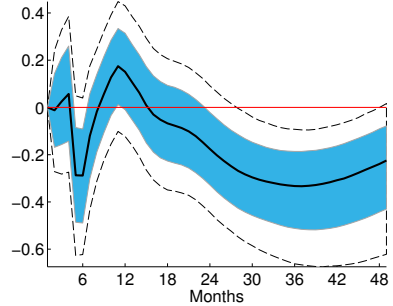

(b)VIX

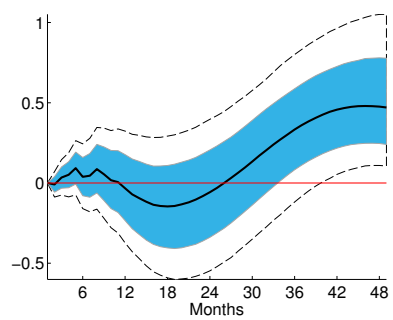

(e)Industrial production (US)

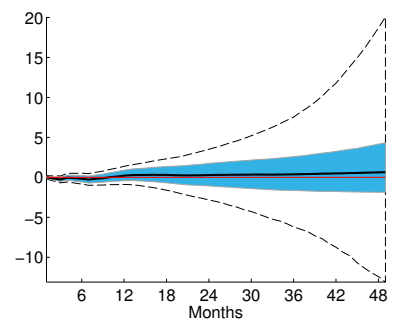

(h)Exchange rate

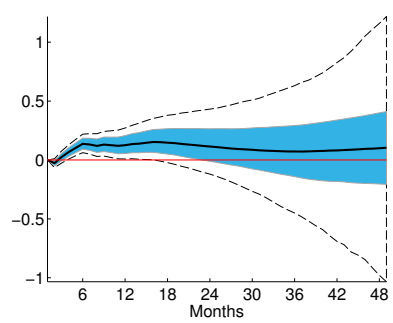

(k)Price Level (CA)

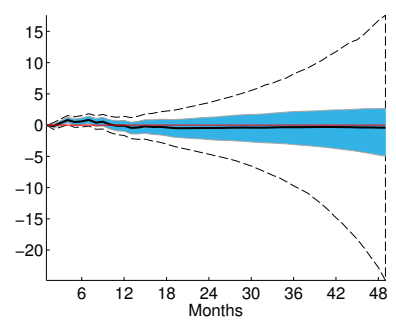

(n)Net Exports (CA)

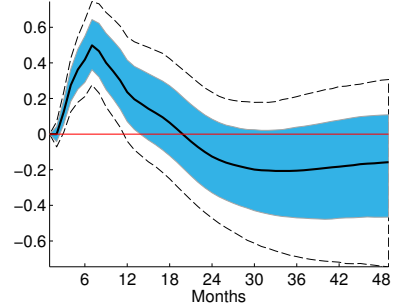

(c)Commodity prices

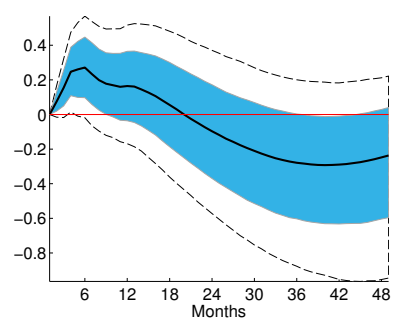

(f)Gov't expenditure (US)

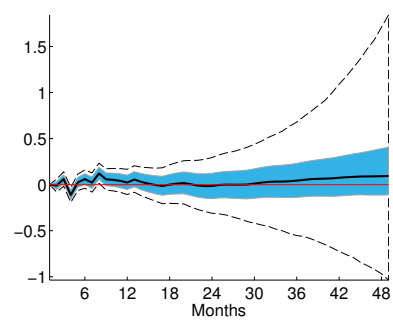

(i)Imports (CA)

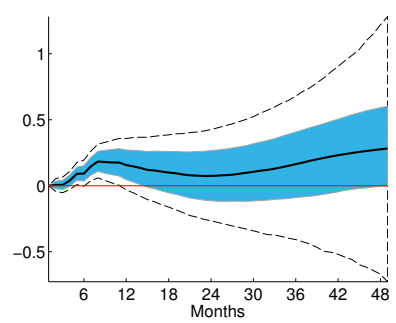

(l)Industrial production (CA)

Note: See figure 3. 
Figure 8. Counterfactual Paths: Canadian ZLB Imposed, Government Expenditure Model

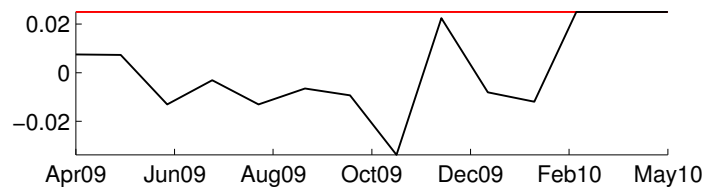

(a)Interest rate

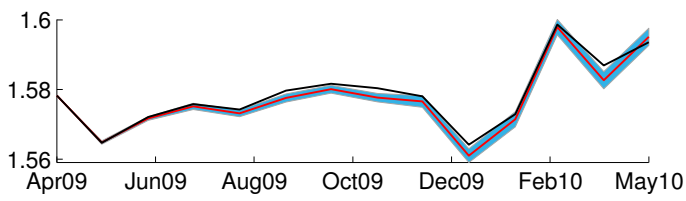

(c)Imports

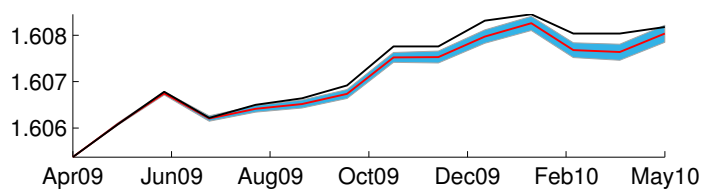

(e)Price Level

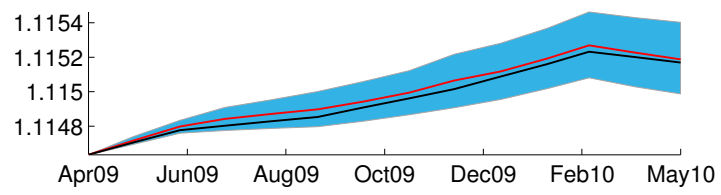

(g)Gov't expenditures

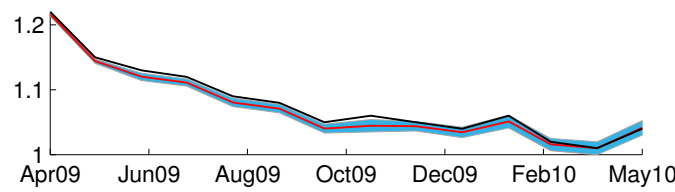

(b)Exchange rate

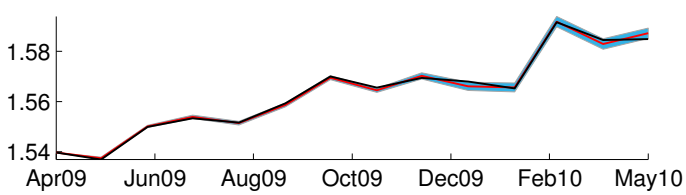

(d)Exports

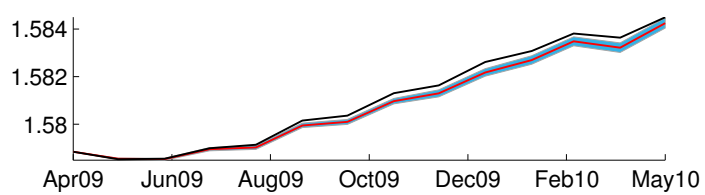

(f)Industrial production

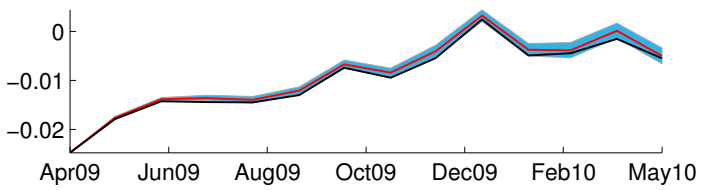

(h)Net Exports

Note: See Figure 4.

where $t$ denotes a quarter of a year and $\mathrm{t}-1$ denotes the previous quarter. $F F R$ denotes the quarterly average of the effective federal funds rate while the hat denotes a prescribed value, $\pi$ denotes the actual rate of inflation and $\pi^{*}$ the target rate of inflation, which we set to $2 \%$, gap is the estimated output gap and $r_{t}^{*}$ the estimated natural (real) rate of interest. We use estimates from Holston, Laubach, and Williams (2017) for the natural rate of interest. ${ }^{20} \mathrm{We}$ use the Congressional Budget Office's real GDP gap as the output gap. We assume the weight on the output gap, $\beta$, to be 0.5 and the weight on the interest rate smoothing parameter, $\rho$, to be zero, which are generally accepted values in the literature.

\footnotetext{
${ }^{20}$ We choose this measure of the natural rate of interest because the authors estimate a rate for both Canada and the US, which provides us with the most consistent estimate of the Taylor Rule for both countries.
} 
Figure 9. Counterfactual Paths: US ZLB Imposed, Government Expenditure Model

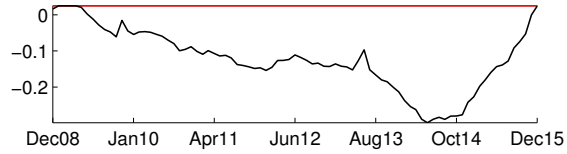

(a)Interest Rate (US)

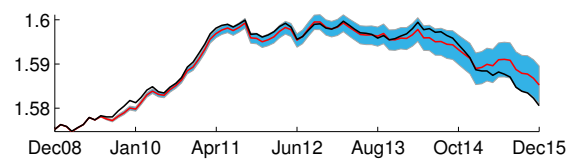

(c)Commodity prices

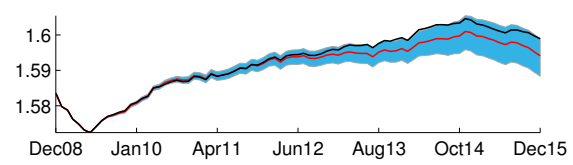

(e)Industrial production (US)

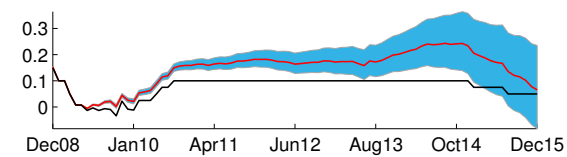

(g)Interest rate

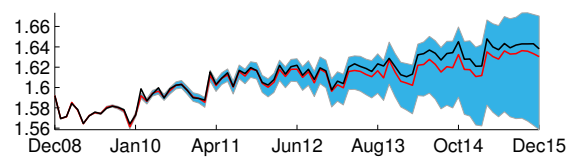

(i)Imports

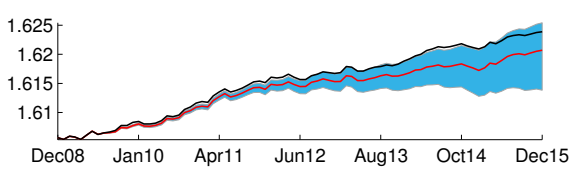

(k)Price Level

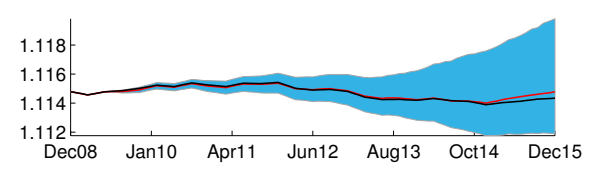

(m)Gov't expenditures

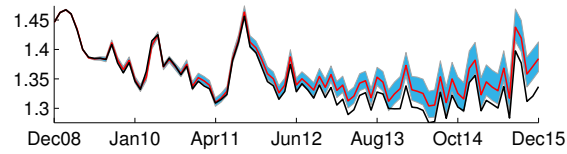

(b)VIX

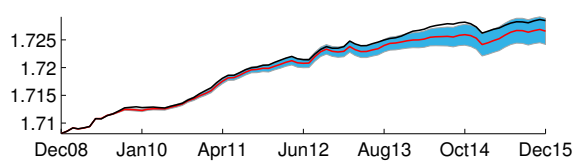

(d)Price Level (US)

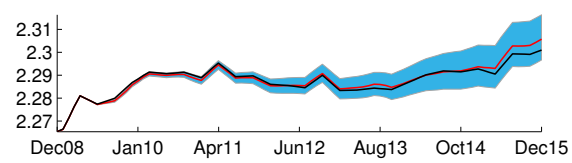

(f)Gov't expenditure (US)

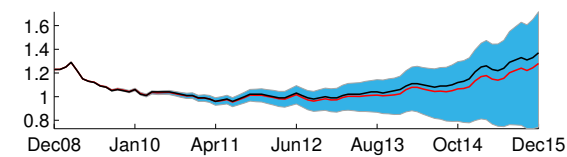

(h)Exchange rate

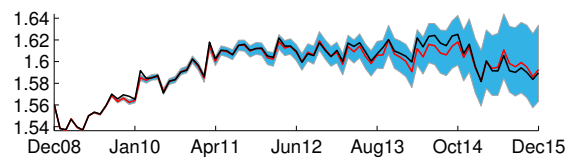

(j)Exports

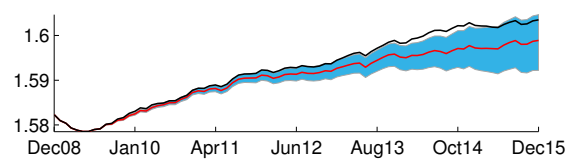

(1)Industrial production

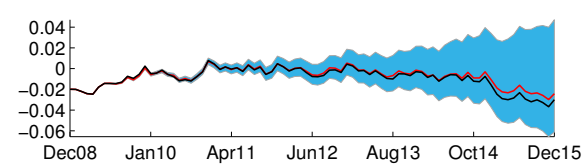

(n)Net Exports

Note: Note: See Figure 5. 
Table 4. Average Counterfactual Path for ZLB, Government Expenditure Model

\begin{tabular}{|c|c|c|c|c|c|c|}
\hline \multirow{3}{*}{ Variable } & \multicolumn{3}{|c|}{ Canadian ZLB Imposed } & \multicolumn{3}{|c|}{ US ZLB Imposed } \\
\hline & \multirow[t]{2}{*}{ Mean } & \multicolumn{2}{|c|}{$68 \%$ Conf. Bound } & \multirow[t]{2}{*}{ Mean } & \multicolumn{2}{|c|}{$68 \%$ Conf. Bound } \\
\hline & & Min & Max & & Min & Max \\
\hline & \multicolumn{6}{|c|}{ Percent Difference } \\
\hline Canadian Interest rate & 0.031 & 0.031 & 0.031 & 0.073 & 0.022 & 0.133 \\
\hline Canadian CPI & -0.008 & -0.013 & -0.003 & -0.101 & -0.226 & -0.004 \\
\hline Canadian industrial production & $\mathrm{n}-0.012$ & -0.018 & -0.006 & -0.137 & -0.275 & -0.012 \\
\hline US interest rate & & & & 0.157 & 0.157 & 0.157 \\
\hline US CPI & & & & -0.055 & -0.114 & 0.001 \\
\hline \multirow[t]{2}{*}{ US industrial production } & & & & -0.098 & -0.260 & 0.046 \\
\hline & \multicolumn{6}{|c|}{ Cumulative Percent Difference } \\
\hline Canadian industrial production & $\mathrm{n}-0.165$ & -0.353 & -0.003 & -10.95 & -22.01 & -0.921 \\
\hline \multirow[t]{2}{*}{ US industrial production } & & & & -7.804 & -20.80 & 3.688 \\
\hline & \multicolumn{6}{|c|}{ Unit Difference } \\
\hline Canad & 1.000 & & 1.000 & 1.000 & 1.000 & 1.000 \\
\hline Canad & -0.682 & -1.094 & -0.276 & -3.088 & -9.249 & -1.214 \\
\hline Canadian industrial produ & $\mathrm{n}-1.011$ & -1.482 & -0.547 & -4.462 & -10.622 & -0.887 \\
\hline US interest $\mathrm{I}$ & & & & 1.000 & 1.000 & 1.000 \\
\hline US CPI & & & & -1.731 & -3.867 & 0.310 \\
\hline \multirow[t]{2}{*}{ US industrial production } & & & & -4.377 & -9.957 & 0.391 \\
\hline & \multicolumn{6}{|c|}{ Unit Percent Difference } \\
\hline Canadian industrial production & $\mathrm{n}-11.12$ & -16.30 & -6.02 & -356.9 & -849.8 & 70.97 \\
\hline US industrial production & & & & -350.2 & -796.6 & 31.32 \\
\hline
\end{tabular}

Note: See Table 3.

We take the same approach for calculating a Canadian Taylor Rule, replacing the $F F R$ with the Bank of Canada's target interest rate. We use Holston, Laubach, and Williams (2017) estimated natural interest rate for Canada and the Bank of Canada's published output gap series. Finally, we assume the target interest rate for Canada is also $2 \%$, which is consistent with the Bank of Canada's mandate, and the same weight on the output gap and interest rate smoothing parameters as for the US rate. For both the US and Canadian rates, the Taylor Rule rates are calculated at a quarterly frequency, matching the output gap and natural interest rate series, and then linearly interpolated to monthly series.

Figure 10 plots the two Taylor Rule interest rates along with the actual policy rates for both countries. It's clear that the Taylor Rule rates do not follow the observed rate very closely, particularly for Canada. Despite this, in both cases the Taylor Rule rate does go below the ZLB during (at least part of) the unconventional monetary policy regimes in both countries. 
Figure 10. Canadian and US Policy Rates and Taylor Rule Rates1994-2016

(a)Canadian Rates

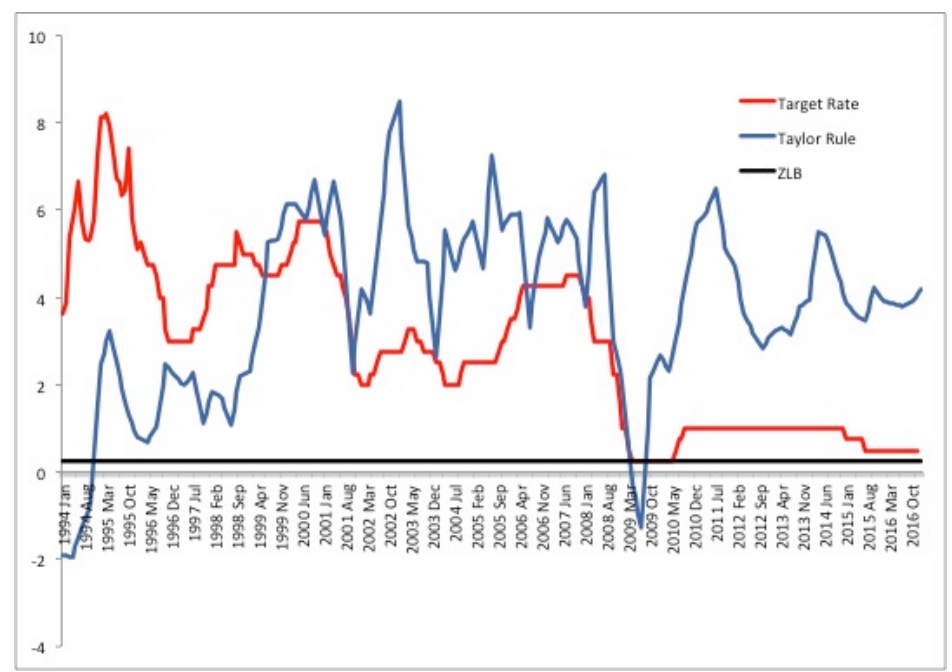

(b)US Rates

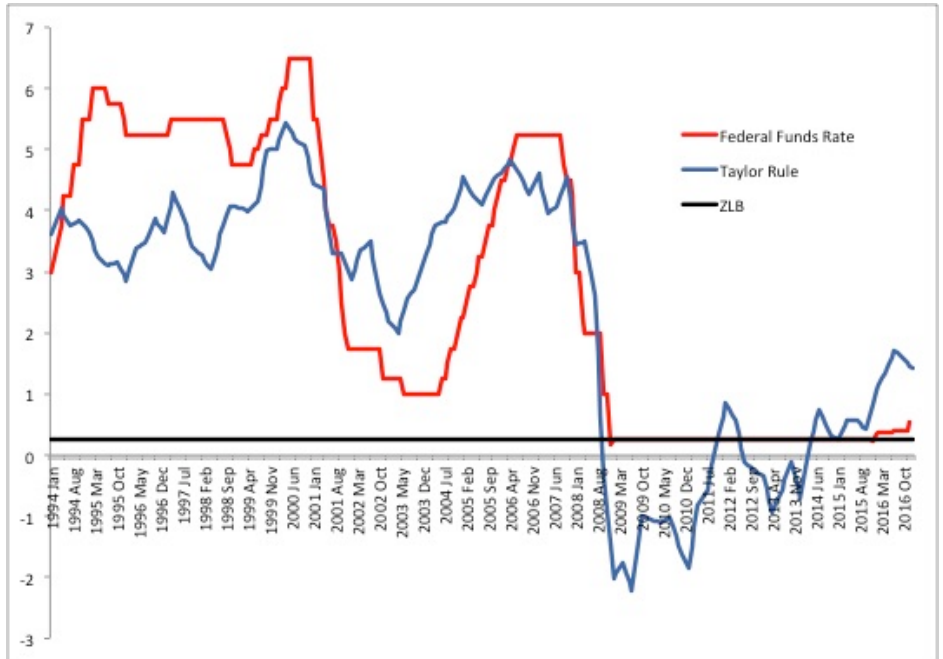

Note: The federal funds rate is the target federal funds rate before November 2008 and the upper bound of the federal funds rate from November 2008 onwards.

Source: FRED, Statistics Canada CANSIM, Bank of Canada, Holston, Laubach, and Williams (2017), Federal Reserve Bank of Atlanta, Taylor (1993), Taylor (1999), and authors' own calculations.

We construct the policy rate according to the same definition as the shadow rate, (1), but using the prescribed Taylor Rule rate. That is, we use the prescribed rate when the Federal Funds Rate or the Bank of Canada's policy rate is at the ZLB and the prescribed Taylor Rule rate is below the ZLB. Unlike the shadow rate there are several months in both countries when the prescribed Taylor Rule rate was greater than $25 \mathrm{bps}$, while the official rates were 25 bps. In these cases, we set the policy rate to 25 bps (in accordance with the definition in (1) 
Impulse response results are presented in Figures 11 and 12. As in the main model, we see that a Canadian interest rate shock is associated with a significant rise in the price level and industrial production, a depreciation of the currency and a slight fall in net exports. The US interest rate shock shows similar strong spillovers to Canada, with Canadian prices rising after about six months (albeit not statistically significant at the more 90 percent level) and industrial production after about 25 months.

The counterfactual estimates are plotted in Figures 13 and 14, and the values reported in Table 5. In both cases, but particularly the Canadian ZLB period, the Taylor Rule implied policy rate was below the ZLB for a much shorter time than the shadow rate but was more negative.

These estimates of our model using the prescribed Taylor Rule rate in place of the shadow rate are highly robust to our main model. This is true even even though the Taylor Rule rate was below the ZLB for less time than the shadow rate. This is because they are driven by the much more negative rate prescribed by the Taylor Rule compared to the shadow rate. Further, under the estimates presented here we see the difference between the observed and counterfactual path of industrial production and prices is much more distinct than in the main model. This finding further supports our argument that we are estimating a lower bound of the impact of unconventional monetary policy in our main model with the shadow rate. 
Figure 11. Impulse Response Functions: Canadian Monetary Policy Shock, Taylor Rule

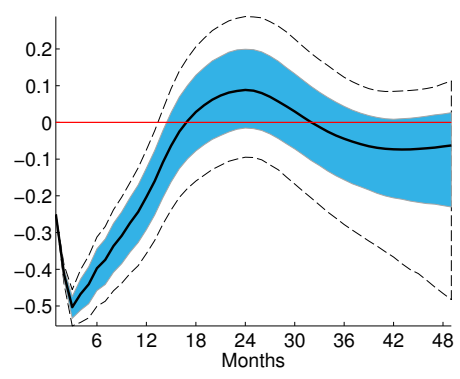

(a) Interest rate

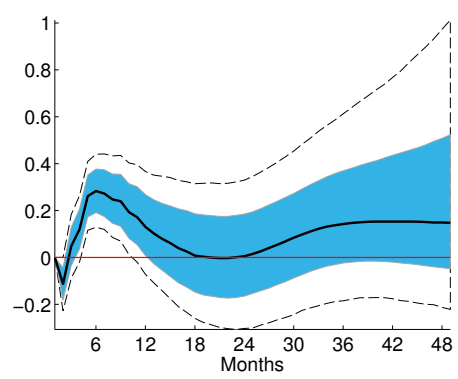

(d)Industrial production

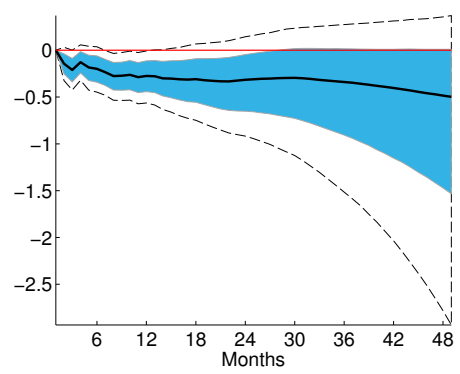

(g)Net Exports

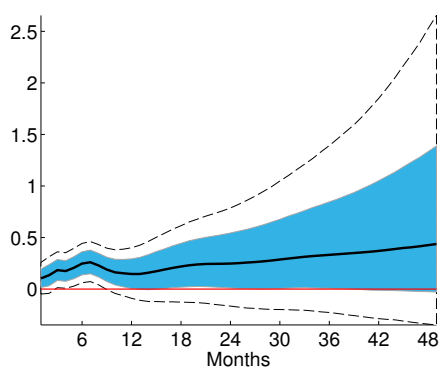

(b)Exchange rate

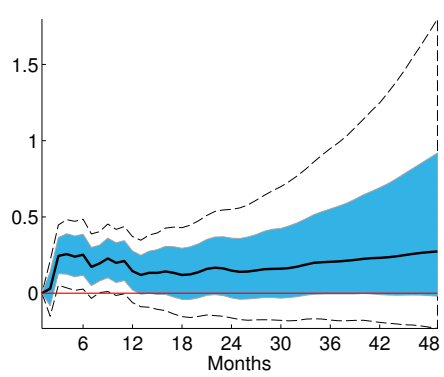

(e)Imports

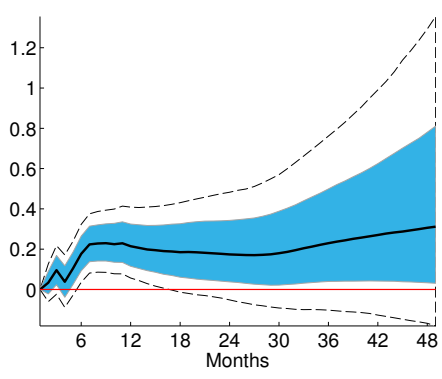

(c)Price Level

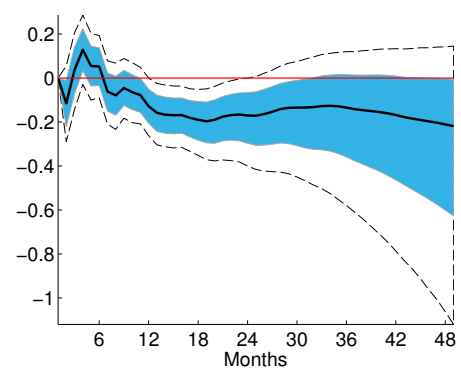

(f)Exports

Note: See figure 2. 
Figure 12. Impulse Response Functions: US Monetary Policy Shock, Taylor Rule

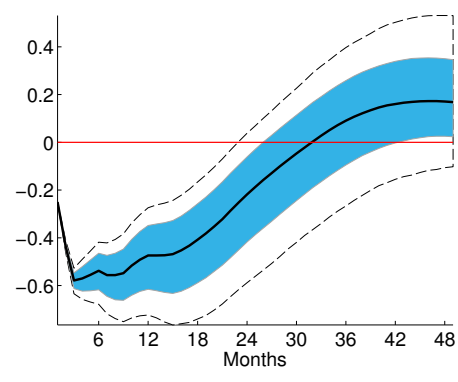

(a)Interest Rate (US)

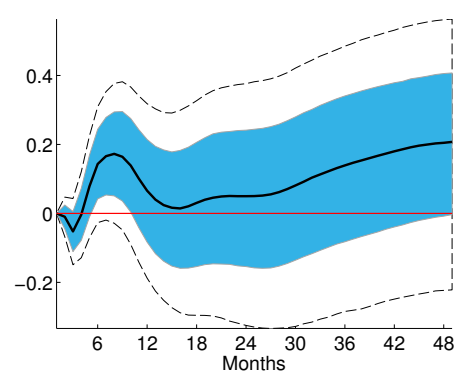

(d)Price Level (US)

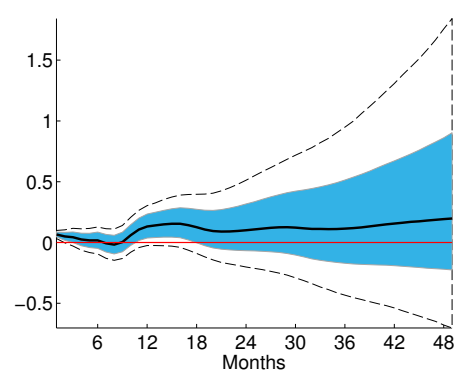

(g)Exchange rate

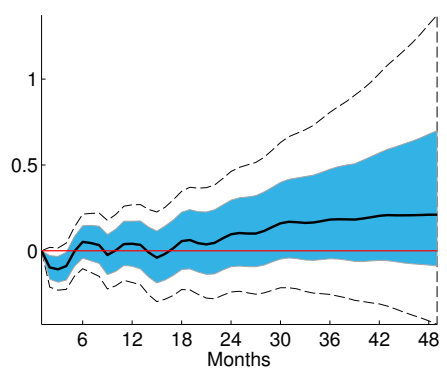

(j)Imports (CA)

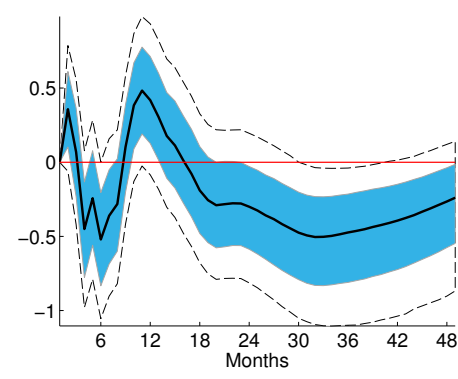

(b)VIX

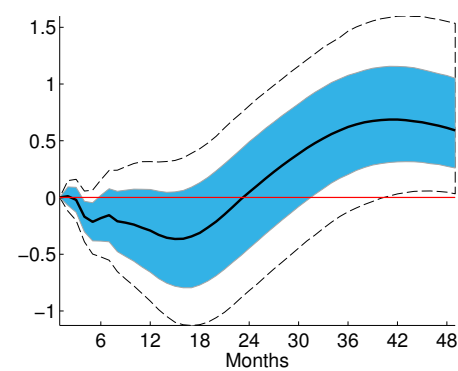

(e)Industrial production (US)

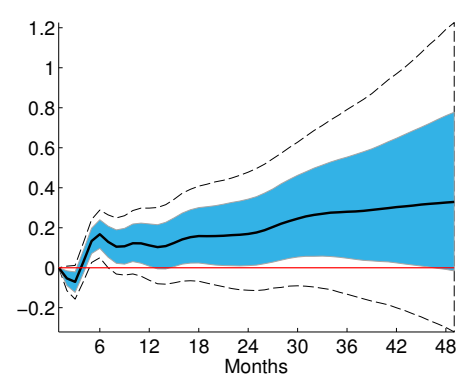

(h)Price Level (CA)

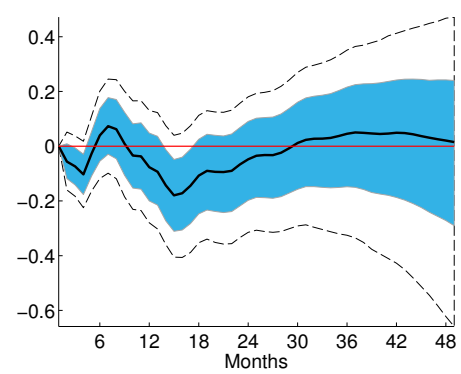

(k)Exports (CA)

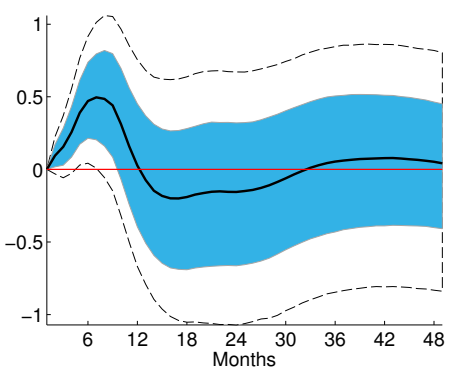

(c)Commodity prices

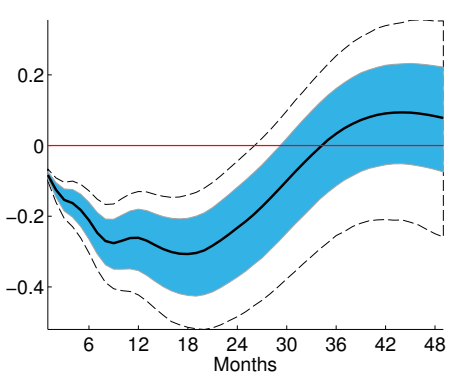

(f)Interest Rate (CA)

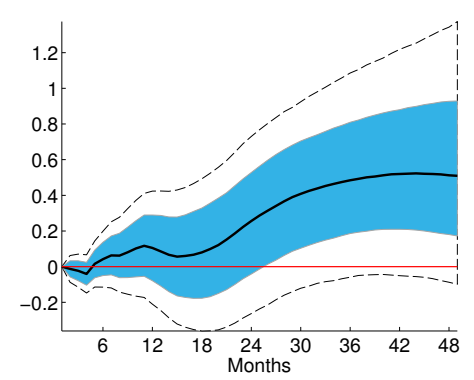

(i)Industrial production (CA)

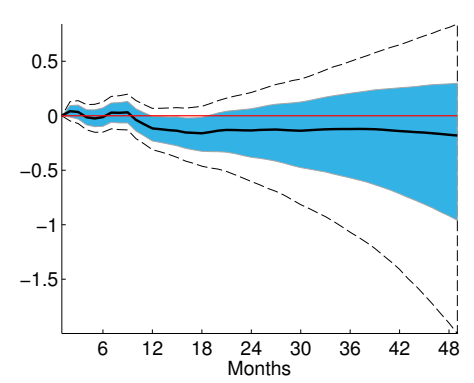

(1)Net Exports (CA)

Note: See Figure ??. 
Figure 13. Counterfactual Paths: Canadian ZLB Imposed, Taylor Rule

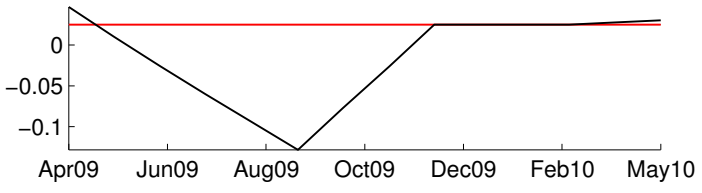

(a)Interest rate

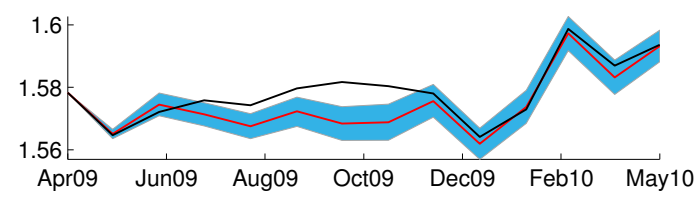

(c)Imports

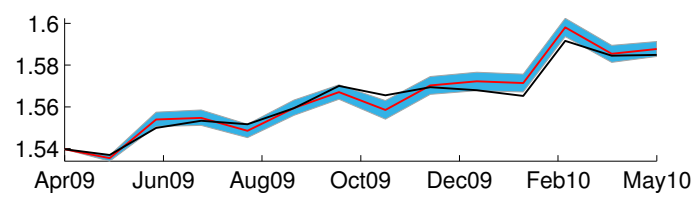

(d)Exports

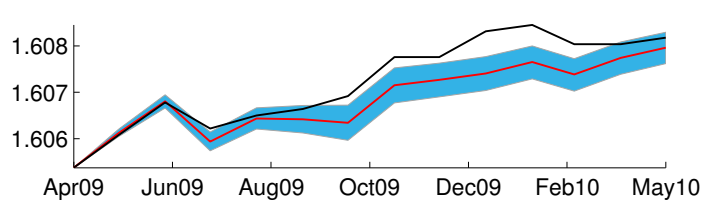

(f)Price Level

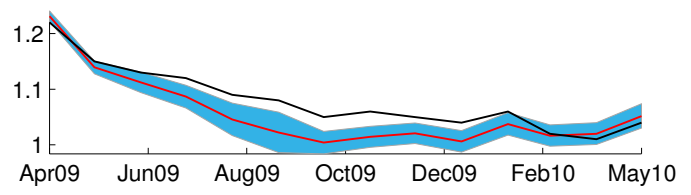

(b)Exchange rate

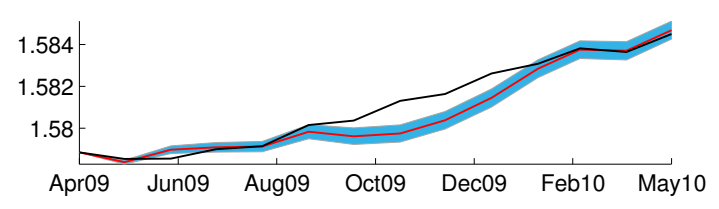

(e)Industrial production

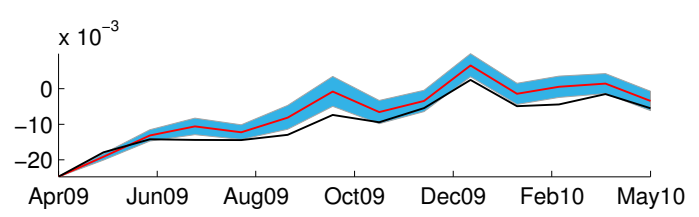

(g)Net Exports

Note: See Figure ??.

\section{Current Account}

As a third robustness exercise, we replace our import and export variables with estimates of the current account. The purpose is to capture both the trade balance and international receipts and payments of income. In Canada from 1994 to 2016, receipts of income from abroad accounted for about 9 percent of all current account receipts, and payments of income from abroad account for about 15 percent of current account payments, on average. Thus, by simply looking at the trade balance we may miss a large component of Canadian international borrowing and lending, and thereby missing important real spillovers from the US to the Canadian economy. 
Figure 14. Counterfactual Paths: US ZLB Imposed, Taylor Rule

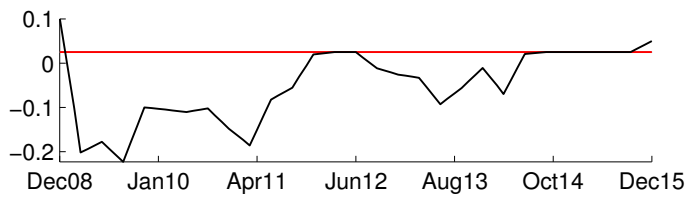

(a)Interest Rate (US)

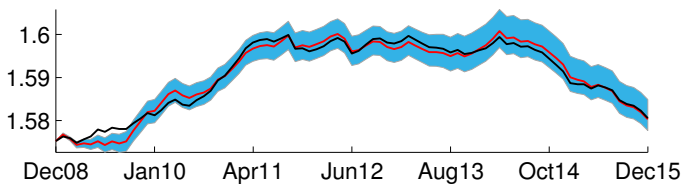

(c)Commodity prices

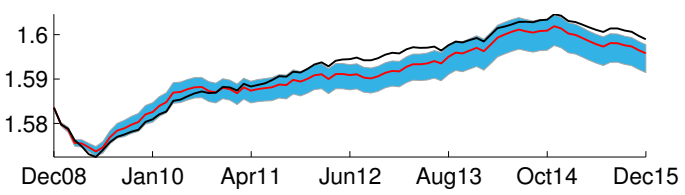

(e)Industrial production (US)

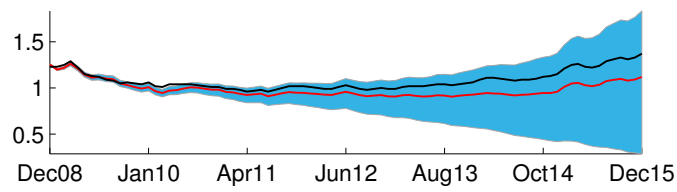

(g)Exchange rate

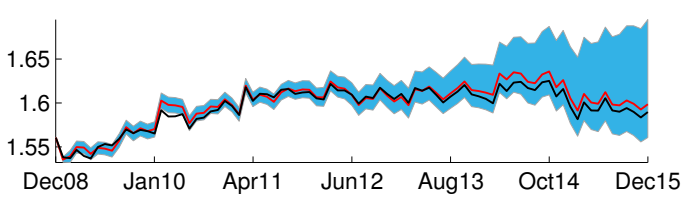

(i)Exports

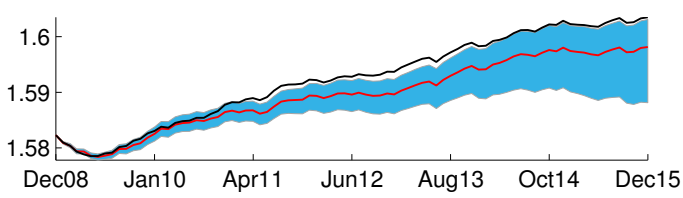

(k)Industrial production

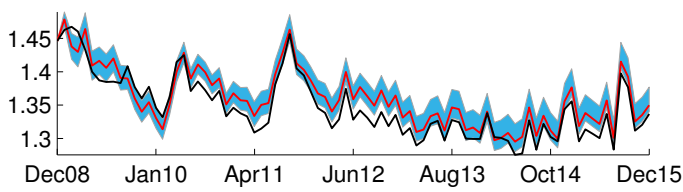

(b) VIX

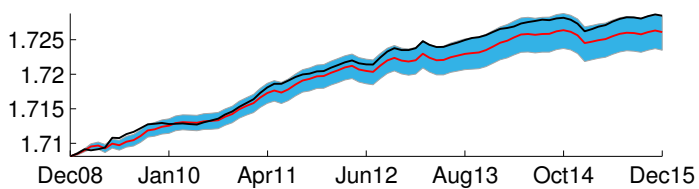

(d)Price Level (US)

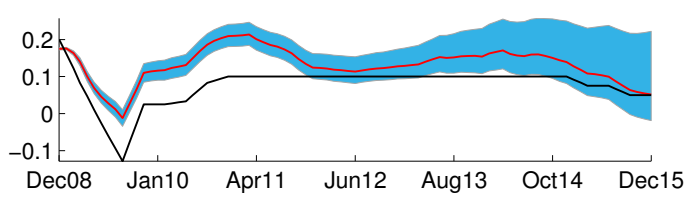

(f)Interest rate

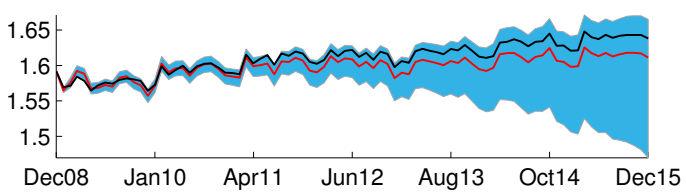

(h)Imports

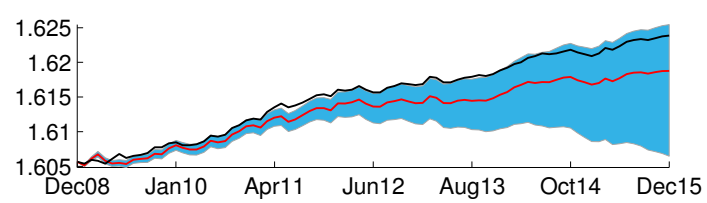

(j)Price Level

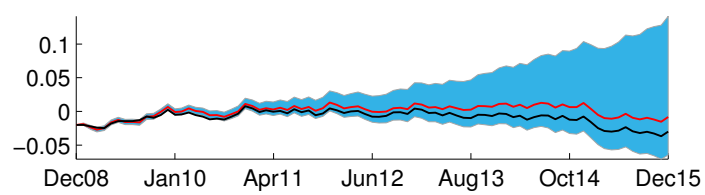

(1)Net Exports

Note: See Figure 5. 
Table 5. Average Counterfactual Path for ZLB, Taylor Rule

\begin{tabular}{|c|c|c|c|c|c|c|}
\hline \multirow{3}{*}{ Variable } & \multicolumn{3}{|c|}{ Canadian ZLB Imposed } & \multicolumn{3}{|c|}{ US ZLB Imposed } \\
\hline & \multirow[t]{2}{*}{ Mean } & \multicolumn{2}{|c|}{$68 \%$ Conf. Bound } & \multirow[t]{2}{*}{ Mean } & \multicolumn{2}{|c|}{$68 \%$ Conf. Bound } \\
\hline & & Min & Max & & Min & $\operatorname{Max}$ \\
\hline & \multicolumn{6}{|c|}{ Percent Difference } \\
\hline Canadian Interest rate & 0.050 & 0.050 & 0.050 & 0.058 & 0.019 & 0.120 \\
\hline Canadian CPI & -0.022 & -0.038 & -0.006 & -0.153 & -0.398 & 0.011 \\
\hline Canadian industrial production & $n-0.028$ & 0.046 & -0.010 & -0.188 & -0.433 & -0.023 \\
\hline US interest rate & & & & 0.075 & 0.075 & 0.075 \\
\hline US CPI & & & & -0.073 & -0.178 & 0.029 \\
\hline \multirow[t]{2}{*}{ US industrial production } & & & & -0.106 & -0.301 & 0.034 \\
\hline & \multicolumn{6}{|c|}{ Cumulative Percent Difference } \\
\hline Canadian industrial production & $\mathrm{n}-0.143$ & -0.344 & 0.057 & -8.853 & -29.929 & 4.282 \\
\hline \multirow[t]{2}{*}{ US industrial production } & & & & -4.283 & -25.426 & 8.859 \\
\hline & \multicolumn{6}{|c|}{ Unit Difference } \\
\hline Canadian Interest rate & 1.000 & 1.000 & 1.000 & -0.009 & 1.331 & 3.902 \\
\hline Canadian CPI & -0.150 & -0.349 & 0.047 & 4.977 & -4.251 & 5.944 \\
\hline Canadian industrial production & $n-0.324$ & -0.092 & -0.553 & -1.509 & -8.368 & 2.503 \\
\hline US interest rate & & & & 1.000 & 1.000 & 1.000 \\
\hline US CPI & & & & -4.518 & -4.582 & 1.301 \\
\hline \multirow[t]{2}{*}{ US industrial production } & & & & -3.321 & -8.667 & 0.711 \\
\hline & \multicolumn{6}{|c|}{ Cumulative Unit Difference } \\
\hline Canadian industr & $n-2.589$ & -5.661 & 0.460 & -104.10 & -412.50 & 926.72 \\
\hline US industrial production & & & & -229.18 & -1021.8 & 206.28 \\
\hline
\end{tabular}

Note: See Table 3.

We replace export and import variables in the main model with a single current account variable, ordered first, in the vector of Canada variables, $Y_{t}^{\mathrm{CAN}}$. We create a monthly series by interpolating (linearly) quarterly values (see Appendix A for details), and do not take the log of the current account, as it can take on negative values. Figure 15 reports the impulse response functions for a 25 bps expansionary monetary policy shock in Canada. As in Section IV both the price level and industrial production rise, but the initial exchange rate depreciation is no longer statistically significant. We observe no significant impact on the Canadian current account. The Canadian impulse response functions for a 25 bps expansionary monetary policy shock in the US are reported in Figure $16 .^{21}$ The results are also largely consistent with those in Section IV. Prices fall significantly on impact, albeit very temporarily, and rise after a lag of about 5 months. Industrial production rises after approximately a two year lag, following the path of US industrial production. As in our main results, the currency depreciates as

\footnotetext{
${ }^{21}$ Because of our block exogeneity assumption, the effect on US variables is identical to the main specification. We do not show them again here.
} 
the Canadian policy rate falls, albiet not significantly. Finally, we see a significant rise in the Canadian current account balance, which along with our main trade results, suggests that rising income in the US has a substantial spillover to Canada via an income effect (that is, rising US income receipts flowing to Canada).

Figure 15. Impulse Response Functions: Canadian Monetary Policy Shock, Current Account Model

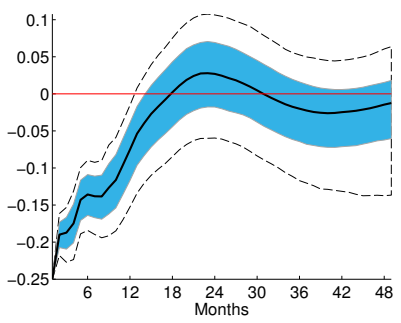

(a)Interest rate

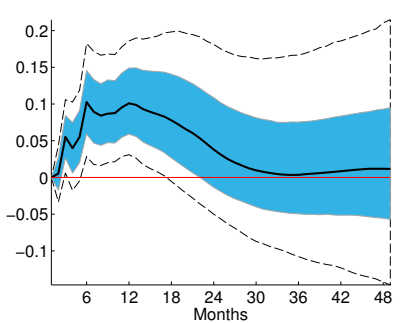

(d)Price Level

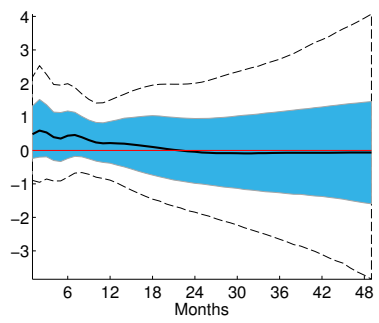

(b)Exchange rate

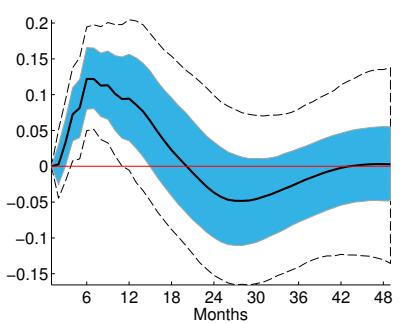

(e)Industrial production

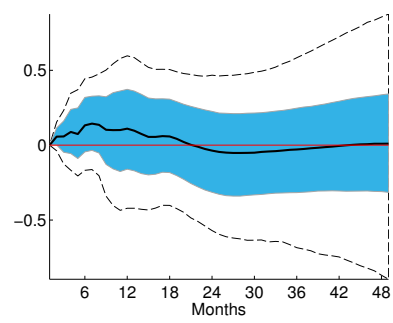

(c)Current account

Note: See figure 2 
Figure 16. Impulse Response Functions: US Monetary Policy Shock, Current Account Model

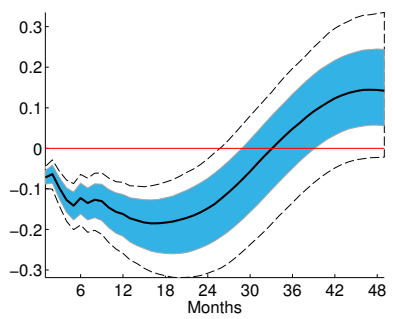

(a)Interest rate

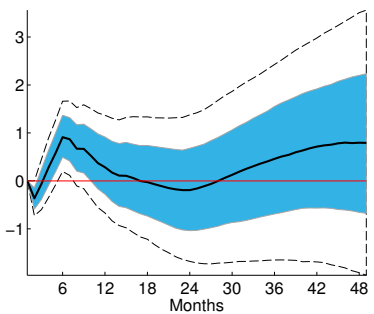

(d)Price Level

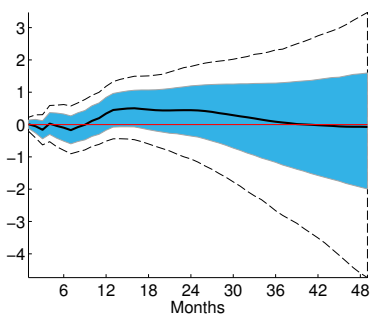

(b)Exchange rate

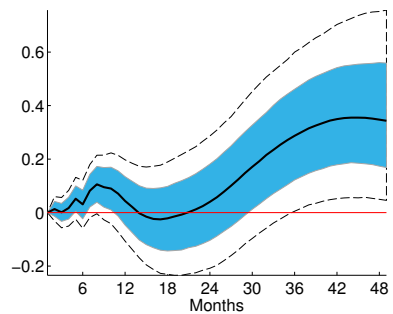

(e)Industrial production

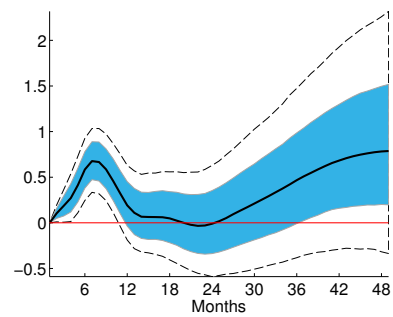

(c)Current account

Note: See figure 3. US impulse response functions, are unchanged from Figure 3 when we replace exports and imports with the current account balance.

The counterfactual experiments are reported in Figures 17 and 18 and Table 6, and further support the main model. Under this specification, Canadian industrial production would have been about 0.014 percent lower on average during the Canadian ZLB without unconventional monetary policies from the Bank of Canada, and 0.111 percent lower on average had the Fed not enacted any unconventional monetary policies. The error bands from these estimates are within the confidence bands of Table 3 .

\section{Alternative Exclusion Restrictions}

We perform a number of robustness exercises that test the exclusion restrictions on our original contemporaneous coefficient matrix. The first is to leave the Bank of Canada's contemporaneous reaction functions unconstrained, which is consistent with our assumption of the Fed's reaction function (but differs from the traditional literature using exclusion restrictions for the Bank of Canada). Results are presented in Appendix D. The estimated impulse response functions are robust for our main variables of interest (industrial production and 
Figure 17. Counterfactual Paths: Canadian ZLB Imposed, Current Account Model

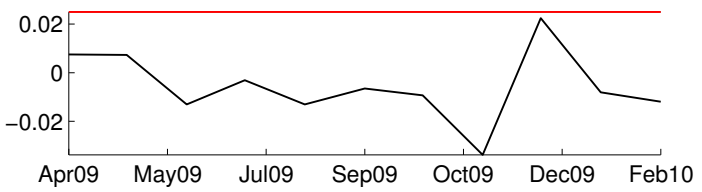

(a)Interest rate

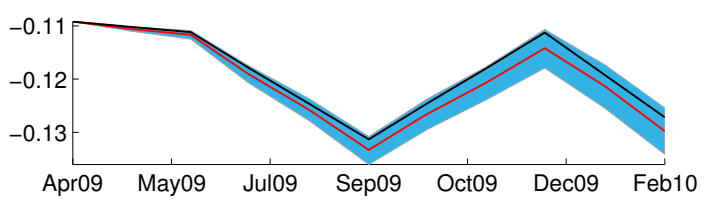

(c)Current account

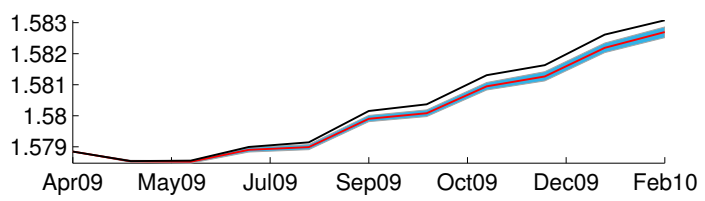

(e)Industrial production

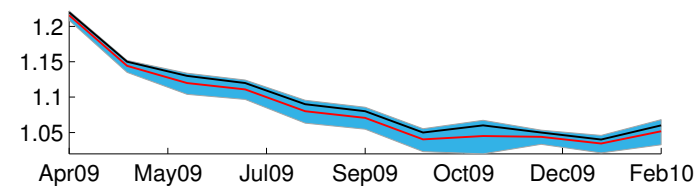

(b)Exchange rate

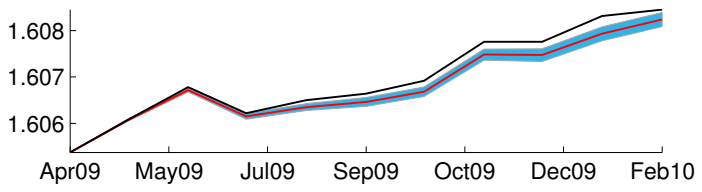

(d)Price Level

Note: See Figure 4 .

prices). ${ }^{22}$ Similarly, our counter factual exercises continue to show that without US and Canadian unconventional monetary policy, Canadian industrial production would have been significantly lower than what was observed.

\section{Conclusion}

This paper contributes to a growing literature on the effects of unconventional monetary policy by analyzing these policies in a small open economy. There are two main challenges for quantifying the effects of unconventional policy in this setting: controlling for the outside world and finding an appropriate policy variable. To deal with these issues, we use the recently proposed shadow rates (Wu and Xia, 2016) as a proxy for monetary policy at the ZLB and construct a block-exogenous B-SVAR model to allow for international policy spillovers. By studying Canada as a candidate small open economy we are able to both assume that the

\footnotetext{
${ }^{22}$ The IRFs are no longer significant at the 90 percent confidence level, but remain statistically significant and approximately similar magnitude at the 68 percent level.
} 
Figure 18. Counterfactual Paths: US ZLB Imposed, Current Account Model

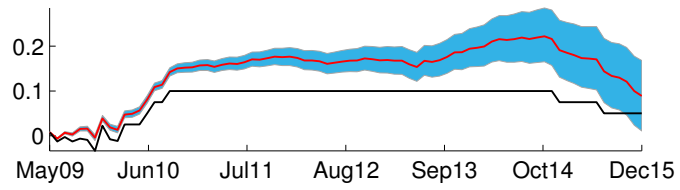

(a)Interest rate

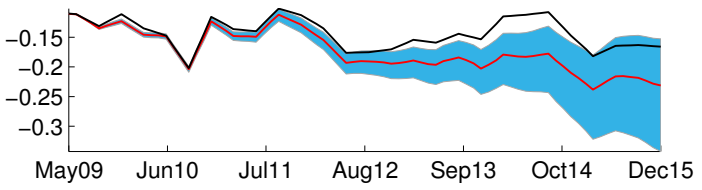

(c)Current account

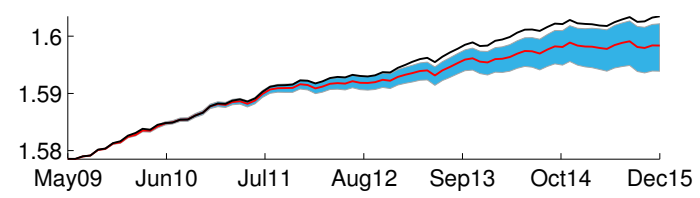

(e)Industrial production

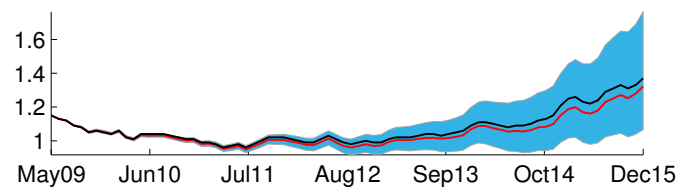

(b)Exchange rate

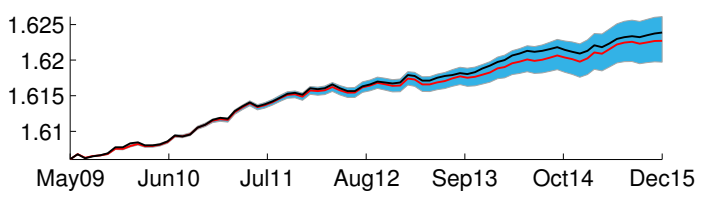

(d)Price Level

Note: See Figure 5. US impulse response functions are unchanged from figure 5 when we replace exports and imports with the current account balance.

US adequately controls for the outside world and to explore the effects of unconventional monetary policy spillovers from the US.

We find that over the 1994-2016 period both Canadian and US expansionary monetary policy shocks were associated with increased industrial production, which we use as a proxy for total output, and prices in Canada. This result is consistent with theoretical and empirical literature based on pre-global financial crisis data. To quantify the magnitude of unconventional monetary policies in both countries, we conduct two counterfactual experiments that restrict the policy rate separately in each country to the ZLB. We find that without the Bank of Canada's unconventional policies, industrial production would have been 0.013 percent lower on average during the Canadian ZLB period. Although these policies had significant expansionary effects, we also show that without them, the Canadian economy would have eventually recovered to the path observed at the end of our sample. The relatively small impact is consistent with the limited unconventional intervention by the Bank of Canada during the ZLB period (that is, no quantitative easing). In contrast, without the Fed's unconventional monetary policies, both Canadian and US industrial production would have been on different 
Table 6. Average Counterfactual Path for ZLB, Current Account Model

\begin{tabular}{|c|c|c|c|c|c|c|}
\hline \multirow{3}{*}{ Variable } & \multicolumn{3}{|c|}{ Canadian ZLB Imposed } & \multicolumn{3}{|c|}{ US ZLB Imposed } \\
\hline & \multirow[t]{2}{*}{ Mean } & \multicolumn{2}{|c|}{$68 \%$ Conf. Bound } & \multirow[t]{2}{*}{ Mean } & \multicolumn{2}{|c|}{$68 \%$ Conf. Bound } \\
\hline & & Min & Max & & Min & $\operatorname{Max}$ \\
\hline & \multicolumn{6}{|c|}{ Percent Difference } \\
\hline Canadian Interest rate & 0.031 & 0.031 & 0.031 & 0.067 & 0.037 & 0.099 \\
\hline Canadian CPI & -0.010 & -0.016 & -0.005 & -0.029 & -0.092 & 0.039 \\
\hline Canadian industrial production & -0.014 & -0.019 & -0.008 & -0.111 & -0.211 & -0.024 \\
\hline US interest rate & & & & 0.157 & 0.157 & 0.157 \\
\hline US CPI & & & & 0.019 & -0.068 & 0.122 \\
\hline \multirow[t]{2}{*}{ US industrial production } & & & & -0.161 & -0.339 & -0.010 \\
\hline & \multicolumn{6}{|c|}{ Cumulative Percent Difference } \\
\hline Canadian industrial production- & --0.075 & -0.135 & -0.015 & -4.157 & -10.636 & 1.326 \\
\hline \multirow{2}{*}{ US industrial production } & & & & -6.159 & -18.784 & 3.882 \\
\hline & \multicolumn{6}{|c|}{ Unit Difference } \\
\hline Canadian Interest rate & 1.000 & 1.000 & 1.000 & 1.000 & 1.000 & 1.000 \\
\hline Canadian CPI & -0.866 & -1.307 & -0.446 & -1.069 & -3.813 & 2.022 \\
\hline Canadian industrial production & -1.126 & -1.599 & -0.635 & -4.713 & -8.901 & -1.157 \\
\hline US interest rate & & & & 1.000 & 1.000 & 1.000 \\
\hline US CPI & & & & 0.164 & -3.158 & 4.280 \\
\hline \multirow[t]{2}{*}{ US industrial production } & & & & -7.025 & -13.557 & -1.826 \\
\hline & \multicolumn{6}{|c|}{ Cumulative Unit Difference } \\
\hline Canadian industrial production & -9.522 & -18.38 & -1.53 & -85.55 & -506.44 & 405.57 \\
\hline US industrial production & & & & -561.98 & -1578.5 & 106.92 \\
\hline
\end{tabular}

Note: See Table 3.

paths at the end of 2016. On average, over the July 2007- December 2015 period, US policies boosted industrial production by approximately 0.157 percent in the US and 0.127 percent in Canada on average. Our results are robust to alternative specifications, including controlling for government spending, using a Taylor Rule, using an alternative definition of bilateral integration that accounts for cross-border income flows, and alternative exclusion restrictions on our main model.

Our findings reveal that unconventional monetary policy in a small open economy is effective, but underlines the importance of favorable foreign monetary policy spillovers. Recent concerns about the large adverse cross-border spillovers of unconventional monetary policies have rekindled the discussion of international coordination of monetary policy and the need for individual countries to acknowledge their role in spillovers. However, as we demonstrate, in some cases these spillovers may have beneficial effects on economic recover. That the Bank of Canada ceased UMP operation long before the Fed yet still benefited from spill- 
overs supports existing literature related to global financial cycles driven by centre countries. Future research should, in a similar vein, quantify the costs and benefits of spillovers from monetary policy normalization or reversal, which will not necessarily have symmetric impacts on small open economies. 


\section{REFERENCES}

Anzuini, Alessio, Marco J Lombardi, and Patrizio Pagano, 2013, "The impact of monetary policy shocks on commodity prices," International Journal of Central Banking, Vol. 9, No. 3, pp. 119-144.

Bank of Canada, 2010, Operating framework for the implementation of monetary policy at the effective lower bound for the overnight interest rate, available at http://www. bankofcanada.ca/wp-content/uploads/2010/04/rate_210409_1.pdf.

Bauer, Michael D, and Christopher J Neely, 2014, "International channels of the Fed's unconventional monetary policy," Journal of International Money and Finance, Vol. 44, pp. 24-46.

Bauer, Michael D, and Glenn D Rudebusch, 2013, "Monetary policy expectations at the zero lower bound," Federal Reserve Bank of San Francisco Working Paper 2013-18.

Baumeister, Christiane, and Luca Benati, 2013, "Unconventional monetary policy and the Great Recession: estimating the macroeconomic effects of a spread compression at the zero lower bound," International Journal of Central Banking, Vol. 9, No. 2, pp. 165-212.

Bekaert, Geert, Marie Hoerova, and Marco Lo Duca, 2013, "Risk, uncertainty and monetary policy," Journal of Monetary Economics, Vol. 60, No. 7, pp. 771-788.

Bernanke, Ben S, and Vincent R Reinhart, 2004, "Conducting monetary policy at very low short-term interest rates," The American Economic Review, Vol. 94, No. 2, p. 85.

Bhuiyan, Rokon, 2012, "Monetary transmission mechanisms in a small open economy: a Bayesian structural VAR approach," Canadian Journal of Economics/Revue canadienne d'économique, Vol. 45, No. 3, pp. 1037-1061.

Black, Fischer, 1995, "Interest rates as options," Journal of Finance, Vol. 50, No. 5, pp. 1371-1376.

Blanchard, O, JD Ostry, and AR Ghosh, 2013, "International policy coordination:

The Loch Ness monster," Available at https://blog-imfdirect.imf.org/2013/12/15/ international-policy-coordination-the-loch-ness-monster/.

Bolder, David Jamieson, Grahame Johnson, and Adam Metzler, 2004, "An empirical analysis of the Canadian term structure of zero-coupon interest rates," Bank of Canada Staff Working Paper 2004-48.

Bowman, David, Juan M Londono, and Horacio Sapriza, 2015, "U.S. unconventional monetary policy and transmission to emerging market economies," Journal of International Money and Finance, Vol. 55, pp. 27-59.

Bruno, Valentina, and Hyun Song Shin, 2015, "Capital flows and the risk-taking channel of monetary policy," Journal of Monetary Economics, Vol. 71, pp. 119-132.

Caceres, Carlos, Yan Carriere-Swallow, Ishak Demir, and Bertrand Gruss, 2016, "US Monetary Policy Normalization and Global Interest Rates," International Monetary Fund Work- 
ing Paper 16/195.

Canova, Fabio, 2005, "The transmission of U.S. shocks to Latin America," Journal of Applied Econometrics, Vol. 20, No. 2, pp. 229-251.

Cecchetti, Stephen, Tommaso Mancini Griffoli, and Machiko Narita, 2017, "Does Prolonged Monetary Policy Easing Increase Financial Vulnerability?” International Monetary Fund Working Paper 17/65.

Chang, Bo Young, and Bruno Feunou, 2013, "Measuring uncertainty in monetary policy using implied volatility and realized volatility," Bank of Canada Staff Working Paper 201337.

Charnavoki, Valery, and Juan J Dolado, 2014, "The effects of global shocks on small commodity-exporting economies: Lessons from Canada," American Economic Journal: Macroeconomics, Vol. 6, No. 2, pp. 207-237.

Chen, Qianying, Andrew Filardo, Dong He, and Feng Zhu, 2015, "Financial crisis, US unconventional monetary policy and international spillovers," IMF Working Paper 85.

Chung, Hess, Jean-Philippe Laforte, David Reifschneider, and John C Williams, 2012, "Have we underestimated the likelihood and severity of zero lower bound events?" Journal of Money, Credit and Banking, Vol. 44, No. s1, pp. 47-82.

Cushman, David O, and Tao Zha, 1995, "Identifying monetary policy in a small open economy under flexible exchange rates," Working Paper, Federal Reserve Bank of Atlanta 957.

1997, "Identifying monetary policy in a small open economy under flexible exchange rates," Journal of Monetary economics, Vol. 39, No. 3, pp. 433-448.

Dahlhaus, Tatjana, Kristina Hess, and Abeer Reza, 2014, "International transmission channels of US quantitative easing: evidence from Canada," Bank of Canada Working Paper 201443.

Dahlhaus, Tatjana, and Garima Vasishtha, 2014, "The impact of US monetary policy normalization on capital flows to emerging-market economies," Bank of Canada Working Paper 2014-53.

D'Amico, Stefania, and Thomas B King, 2013, "Flow and stock effects of large-scale treasury purchases: Evidence on the importance of local supply," Journal of Financial Economics, Vol. 108, No. 2, pp. 425-448.

Dedola, Luca, Giulia Rivolta, and Livio Stracca, 2017, "If the Fed sneezes, who catches a cold?" Journal of International Economics.

Ehrmann, Michael, and Marcel Fratzscher, 2005, "Equal size, equal role? Interest rate interdependence between the Euro Area and the United States," The Economic Journal, Vol. 115, No. 506, pp. 928-948.

Eichengreen, Barry, and Poonam Gupta, 2014, "Tapering talk: the impact of expectations of reduced Federal Reserve security purchases on emerging markets," World Bank Policy 
Research Working Paper 6754.

Engel, Charles, 2015, “International coordination of central bank policy," NBER Working Paper 20952.

Fratzscher, Marcel, Marco Lo Duca, and Roland Straub, 2013, "On the international spillovers of US quantitative easing," DIW Berlin Discussion Paper 1304.

_, 2014 , "ECB unconventional monetary policy actions: market impact, international spillovers and transmission channels," Presented at the 15th Jacques Polak Annual Research Conference, International Monetary Fund.

Gagnon, Joseph, Matthew Raskin, Julie Remache, and Brian P Sack, 2010, "Large-scale asset purchases by the Federal Feserve: did they work?" Federal Reserve Board of New York Staff Report 441.

Gambacorta, Leonardo, Boris Hofmann, and Gert Peersman, 2014, "The effectiveness of unconventional monetary policy at the zero lower bound: A cross-country analysis," Journal of Money, Credit and Banking, Vol. 46, No. 4, pp. 615-642.

Hamilton, James D, and Jing Cynthia Wu, 2012, "The effectiveness of alternative monetary policy tools in a zero lower bound environment," Journal of Money, Credit and Banking, Vol. 44, No. s1, pp. 3-46.

He, Zhongfang, 2010, "Evaluating the effect of the Bank of Canada's conditional commitment policy," Bank of Canada Discussion Paper 2010-11.

Holston, Kathryn, Thomas Laubach, and John C Williams, 2017, "Measuring the natural rate of interest: International trends and determinants," Journal of International Economics.

IMF, 2017, Global Financial Stability Report: Are Countries Losing Control of Domestic Financial Conditions?, available at https://www.imf.org/en/Publications/GFSR/Issues/ 2017/03/30/global-financial-stability-report-april-2017\#Chapter3.

Kozicki, Sharon, Eric Santor, and Lena Suchanek, 2011, "Unconventional Monetary Policy: the international experience with central bank asset purchases," Bank of Canada review, Vol. 2011, No. Spring, pp. 13-25.

Krippner, Leo, 2012, "Modifying Gaussian term structure models when interest rates are near the zero lower bound," .

_ , 2013, "A tractable framework for zero lower bound Gaussian term structure models," Reserve Bank of New Zealand Discussion Paper Series DP2013/02.

Krishnamurthy, Arvind, and Annette Vissing-Jorgensen, 2011, "The effects of quantitative easing on interest rates: channels and implications for policy," NBER Working Paper 17555.

Krishnamurthy, Arvind, Annette Vissing-Jorgensen, and others, 2013, "The ins and outs of LSAPs," in Kansas City Federal Reserve Symposium on Global Dimensions of Unconventional Monetary Policy, pp. 57-111. 
MacDonald, Margaux, 2017, "International capital market frictions and spillovers from quantitative easing," Journal of International Money and Finance, Vol. 70, pp. 135-156.

Maćkowiak, Bartosz, 2007, "External shocks, U.S. monetary policy and macroeconomic fluctuations in emerging markets," Journal of Monetary Economics, Vol. 54, No. 8, pp. 25122520 .

McNeil, James, 2017, "New measures of Canadian monetary policy shocks and their effects," Unpublished Working Paper.

Mishra, Prachi, and Raghuram Rajan, 2016, "Rules of the monetary game," Reserve Bank of India Working Paper Series 4.

Neely, Christopher J, 2015, "Unconventional monetary policy had large international effects," Journal of Banking \& Finance, Vol. 52, pp. 101-111.

Neri, Stefano, and Andrea Nobili, 2010, “The transmission of U.S. monetary policy to the Euro Area," International Finance, Vol. 13, No. 1, pp. 55-78.

Obstfeld, Maurice, 2015, "Trilemmas and Tradeoffs: Living with Financial Globalization," in Claudio Raddatz, Diego Saravia, and Jaume Ventura (eds.), Global Liquidity, Spillovers to Emerging Markets and Policy Responses, Vol. 20, pp. 013-078 (Central Bank of Chile).

Ramey, Valerie A, 2011, "Can government purchases stimulate the economy?" Journal of Economic Literature, Vol. 49, No. 3, pp. 673-685.

— 2016, "Macroeconomic shocks and their propagation," Handbook of Macroeconomics, Vol. 2, pp. 71-162.

Rey, Hélène, 2015, "Dilemma not trilemma: the global financial cycle and monetary policy independence," .

Rogers, John H, Chiara Scotti, and Jonathan H Wright, 2014, "Evaluating asset-market effects of unconventional monetary policy: a multi-country review," Economic Policy, Vol. 29, No. 80, pp. 749-799.

Rossi, Barbara, and Sarah Zubairy, 2011, "What is the importance of monetary and fiscal shocks in explaining US macroeconomic fluctuations?" Journal of Money, Credit and Banking, Vol. 43, No. 6, pp. 1247-1270.

Santor, Eric, and Lena Suchanek, 2016, "A new era of Central Banking: Unconventional monetary policies," Bank of Canada Review, Vol. 2016, No. Spring, pp. 29-42.

Sims, Christopher A, and Tao Zha, 1998, "Bayesian methods for dynamic multivariate models," International Economic Review, Vol. 39, No. 4, pp. 949-968. 1155.

Swanson, Eric T, and John C Williams, 2014, "Measuring the effect of the zero lower bound on medium-and longer-term interest rates," The American Economic Review, Vol. 104, No. 10, pp. 3154-3185. 
Taylor, John B, 1993, "Discretion versus policy rules in practice," in Carnegie-Rochester conference series on public policy, Vol. 39, pp. 195-214 (Elsevier).

_ 1999 , "A historical analysis of monetary policy rules," in Monetary policy rules, pp. 319-348 (University of Chicago Press).

__ , 2013, "International monetary policy coordination: past, present and future," Stanford Institute for Economic Policy Research Discussion Papers 12-034.

Waggoner, Daniel F, and Tao Zha, 2003, "A Gibbs sampler for structural vector autoregressions," Journal of Economic Dynamics and Control, Vol. 28, No. 2, pp. 349-366.

Wu, Jing Cynthia, and Fan Dora Xia, 2016, "Measuring the macroeconomic impact of monetary policy at the zero lower bound," Journal of Money, Credit, and Banking, Vol. 48, No. 2-3, pp. 253-291. 


\section{Appendix A. DATA}

Table 7. Data Sources and Definitions

\begin{tabular}{|c|c|c|}
\hline Variable & Source & Definition \\
\hline$c a$ & $\begin{array}{l}\text { CANSIM, au- } \\
\text { thor's calculation }\end{array}$ & $\begin{array}{l}\text { Current account balance, seasonally adjusted. Quarterly series } \\
\text { linearly interpolated to monthly frequency. }\end{array}$ \\
\hline$g$ & $\begin{array}{l}\text { CANSIM, au- } \\
\text { thor's calcula- } \\
\text { tions }\end{array}$ & $\begin{array}{l}\text { General federal governments final consumption expenditure, } \\
\text { seasonally adjusted at annual rates, chained } 2007 \text { dollars. Quar- } \\
\text { terly series linearly interpolated to monthly frequency. }\end{array}$ \\
\hline$g_{U S}$ & $\begin{array}{l}\text { Federal Reserve } \\
\text { of St. Louis }\end{array}$ & $\begin{array}{l}\text { Federal government final consumption expenditures, seasonally } \\
\text { adjusted at annual rates, chained } 2009 \text { dollars. Quarterly series }\end{array}$ \\
\hline & $\begin{array}{l}\text { Economic Data } \\
\text { (FRED) }\end{array}$ & linearly interpolated to monthly frequency. \\
\hline$p$ & CANSIM & $\begin{array}{l}\text { Consumer Price Index, All items, Index, Monthly, seasonally } \\
\text { adjusted.. }\end{array}$ \\
\hline$p_{U S}$ & FRED & $\begin{array}{l}\text { Consumer Price Index, All items, Index, Monthly, seasonally } \\
\text { adjusted. }\end{array}$ \\
\hline$r$ & $\begin{array}{l}\text { Bank of Canada, } \\
\text { author's calcula- } \\
\text { tions }\end{array}$ & $\begin{array}{l}\text { Bank of Canada target rate spliced with shadow rate at ZLB } \\
\text { when shadow rate }<\text { target rate }=25 \mathrm{bps} \text {, Monthly. }\end{array}$ \\
\hline$r_{U S}$ & $\begin{array}{l}\text { FRED, Wu and } \\
\text { Xia (2016) }\end{array}$ & $\begin{array}{l}\text { Federal funds target rate spliced with Wu and Xia (2016) } \\
\text { shadow rate at ZLB when SSR }<\text { FFR }=25 b p \text {, Monthly. }\end{array}$ \\
\hline$s$ & IFS & $\begin{array}{l}\text { National Currency per US Dollar, National Currency per US } \\
\text { Dollar, Rate, Monthly average. }\end{array}$ \\
\hline vix & CBOE & $\begin{array}{l}\text { Chicago Board Options Exchange (CBOE) VIX index measur- } \\
\text { ing market's expectation of } 30 \text {-day volatility. Constructed using } \\
\text { the implied volatilities of a range of S\&P } 500 \text { index options, } \\
\text { Monthly average. }\end{array}$ \\
\hline$w x p$ & IFS & Export Price, All Commodities, Index, Monthly average. \\
\hline$y$ & IFS & Industrial Production, Seasonally adjusted, Index, Monthly. \\
\hline$y_{U S}$ & IFS & Industrial Production, Seasonally adjusted, Index, Monthly. \\
\hline
\end{tabular}




\section{Appendix B. Alternative Confidence Bands}

Figure 19. Counterfactual Paths: Canadian ZLB Imposed (90\% confidence band)

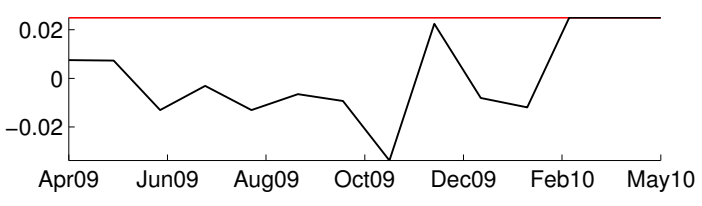

(a)Interest rate

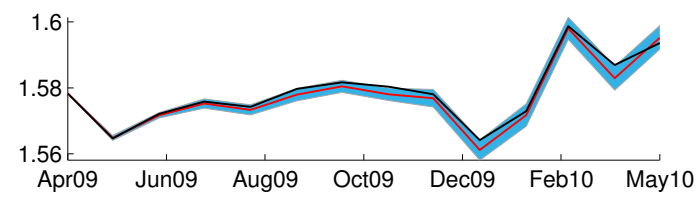

(c)Imports

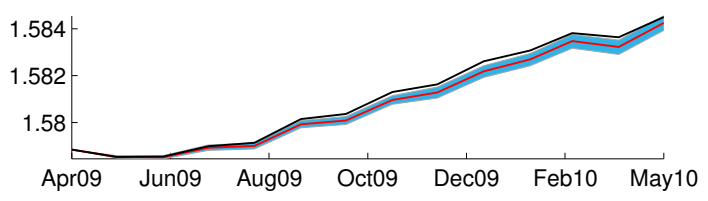

(e)Industrial production

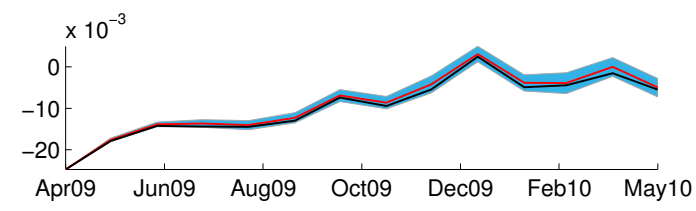

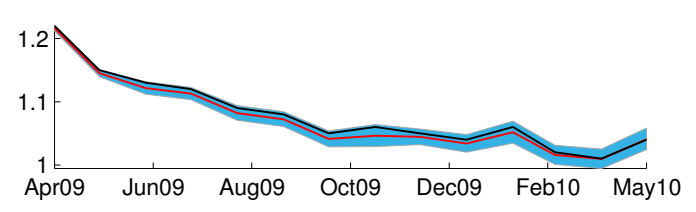

(b)Exchange rate

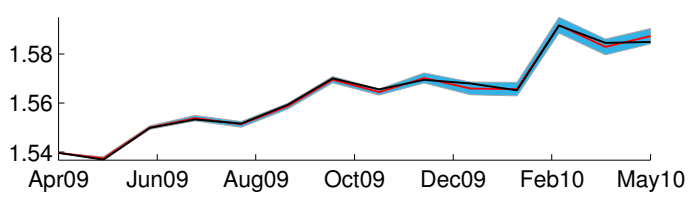

(d)Exports

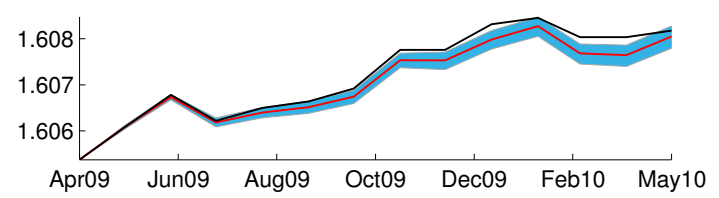

(f)Price Level

\section{(g)Net Exports}

Note: This figure plots the observe value of each series in our model along with an estimate of its counterfactual path, which is constructed by generating a set of structural shocks for the policy rate such that the policy rate is forced to respect the ZLB (25 bps). Error bands are constructed based on 5000 Gibbs sampling draws from the posterior distribution at the 90 percent confidence level. The red line is the counterfactual value, blue band is the error band, and the black line is the real observed value. Net exports are calculated ex-post estimation, not included in the estimated model. 
Figure 20. Counterfactual Paths: US ZLB Imposed (90\% confidence band)

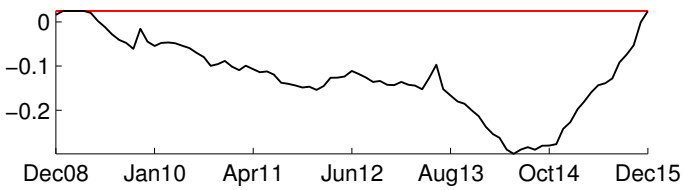

(a)Interest Rate (US)

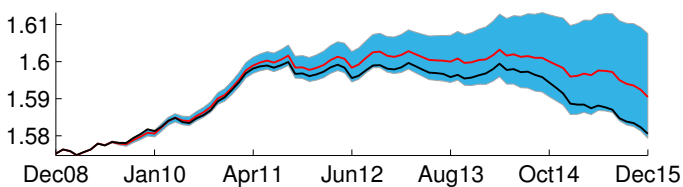

(c)Commodity prices

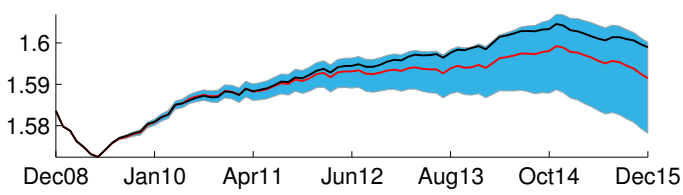

(e)Industrial production (US)

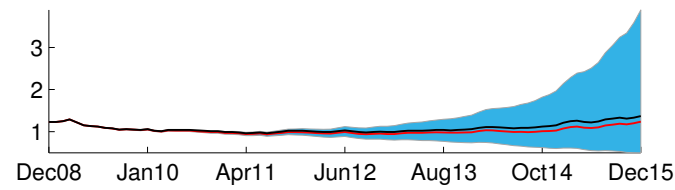

(g)Exchange rate

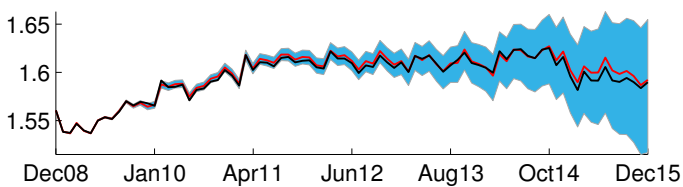

(i)Exports

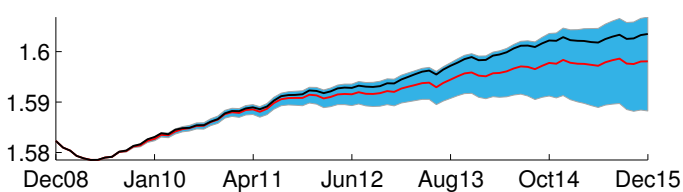

(k)Industrial production

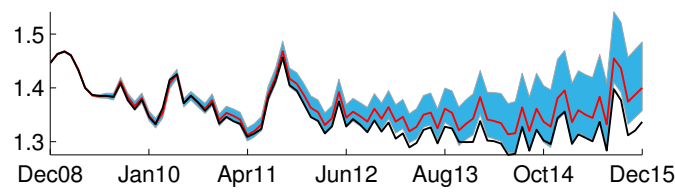

(b)VIX

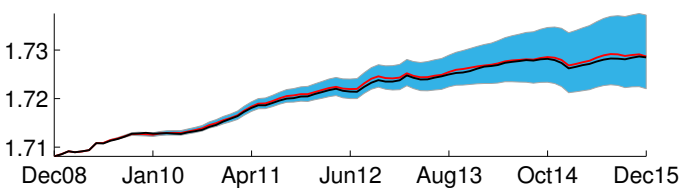

(d)Price Level (US)

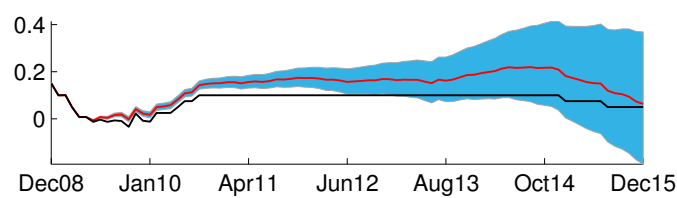

(f)Interest rate

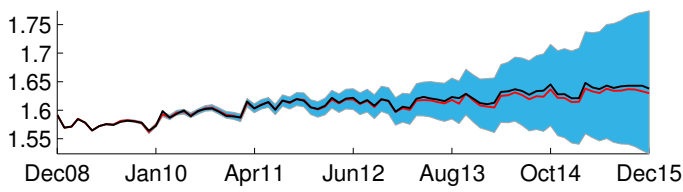

(h)Imports

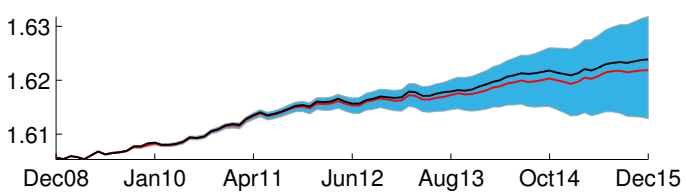

(j)Price Level

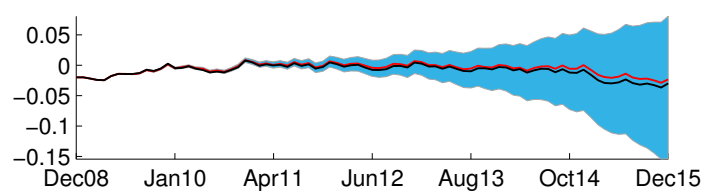

(1)Net Exports

Note: This figure plots the observe value of each series in our model along with an estimate of its counterfactual path, which is constructed by generating a set of structural shocks for the policy rate such that the policy rate is forced to respect the ZLB (25 bps). Error bands are constructed based on 5000 Gibbs sampling draws from the posterior distribution at 90 percent confidence level. The red line is the counterfactual value, blue band is the error band, and the black line is the real observed value. Net exports are calculated ex-post estimation, not included in the estimated model. 
Table 8. Average Counterfactual Path for ZLB (90\% confidence band)

\begin{tabular}{|c|c|c|c|c|c|c|}
\hline \multirow{4}{*}{ Variable } & \multicolumn{3}{|c|}{ Canadian ZLB Imposed } & \multicolumn{3}{|c|}{ US ZLB Imposed } \\
\hline & \multirow[t]{2}{*}{ Mean } & \multicolumn{2}{|c|}{$90 \%$ Conf. Bound } & \multirow{2}{*}{ Mean } & \multicolumn{2}{|c|}{$90 \%$ Conf. Bound } \\
\hline & & Min & Max & & Min & Max \\
\hline & \multicolumn{6}{|c|}{ Percent Difference } \\
\hline Canadian interest rate & 0.031 & 0.031 & 0.031 & 0.063 & -0.014 & 0.155 \\
\hline Canadian CPI & -0.008 & -0.016 & -0.001 & -0.043 & 197 & 0.127 \\
\hline Canadian industrial production & -0.013 & -0.022 & -0.004 & -0.127 & -0.325 & -0.060 \\
\hline US interest rate & & & & 0.157 & 0.157 & 0.157 \\
\hline US CPI & & & & 0.021 & -0.125 & 0.193 \\
\hline \multirow[t]{2}{*}{ US industrial production } & & & & -0.157 & -0.488 & 0.091 \\
\hline & \multicolumn{6}{|c|}{ Unit Difference } \\
\hline Canad & 1.000 & 1.000 & 1.000 & 0.557 & -1.000 & 2.333 \\
\hline Canadian CPI & -0.681 & -1.302 & -0.109 & -1.907 & -9.757 & 7.037 \\
\hline Canadian industrial production & $1-1.062$ & -1.801 & -0.347 & -5.054 & -13.836 & 3.122 \\
\hline US interest rate & & & & 1.00 & 1.00 & 1.00 \\
\hline US CPI & & & & 0.254 & -5.233 & 7.463 \\
\hline US industrial production & & & & -6.817 & -19.566 & 1.611 \\
\hline
\end{tabular}

Note: This table contains the average percentage (top panel) and average unit (bottom panel) differences between the observed values and the counterfactual Mean as well as $90 \%$ bounds. The calculation uses the formula $\frac{1}{\widetilde{T}} \sum_{t \in Z L B} \frac{y_{t}-y_{t}^{C F}}{y_{t}}$ (percent difference) and $\frac{1}{\widetilde{T}} \sum_{t \in Z L B} y_{t}-y_{t}^{C F}$ (unit difference), where $y_{t}$ is the observed value at time $t$ and $y_{t}^{C F}$ is the value under the counterfactual scenario, ZLB denotes the time period for the experiment and $\tilde{T}$ the number of observations for the experiment during the ZLB. Note that in those cases when the max and min bounds include 0 , the possibility that the paths were significantly different from zero for individual months during the experiment period is not excluded. 


\section{APPEndix C. Robustness - Government EX- PENDITURE MODEL, $68 \%$ CONFIDENCE BANDS}

Figure 21. Impulse Response Functions: Canadian Monetary Policy Shock, Government Expenditure Model

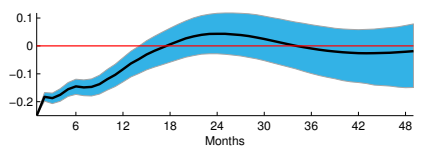

(a)Interest rate

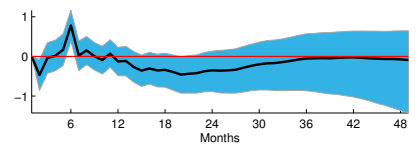

(d)Exports

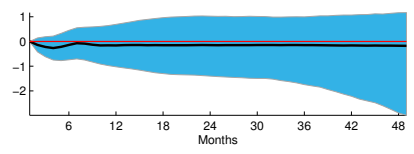

(g)Gov't expenditures

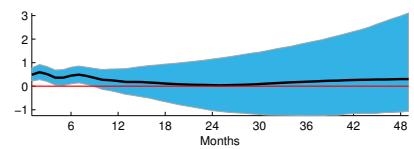

(b)Exchange rate

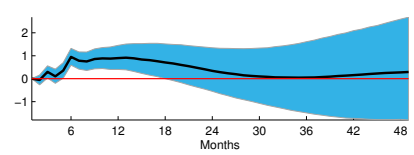

(e)Price Level

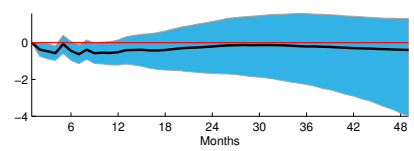

(h)Net Exports

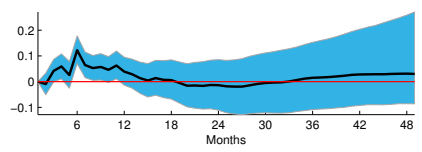

(c)Imports

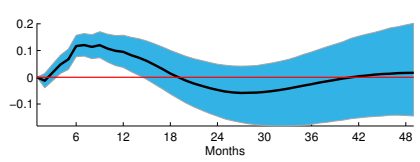

(f)Industrial production

Note: See figure 2. On $68 \%$ confidence bands reported. 
Figure 22. Impulse Response Functions: US Monetary Policy Shock, Government Expenditure Model

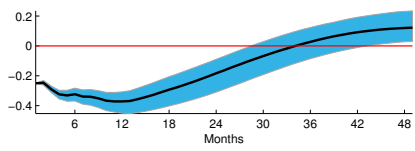

(a)Interest Rate (US)

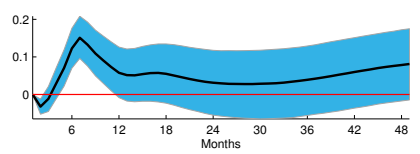

(d)Price Level (US)

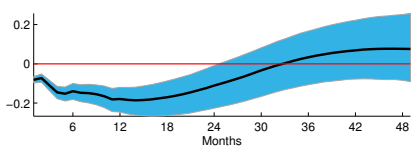

(g)Interest rate (CA)

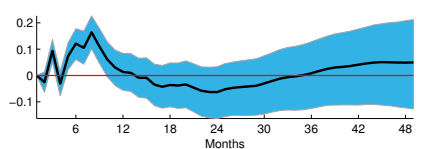

(j)Exports (CA)

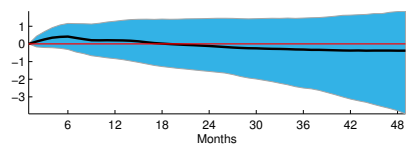

(m)Gov't expenditure (CA)

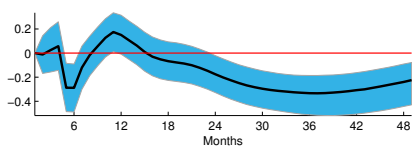

(b)VIX

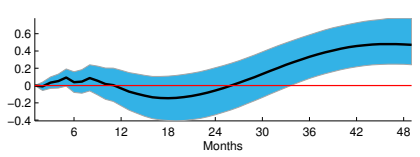

(e)Industrial production (US)

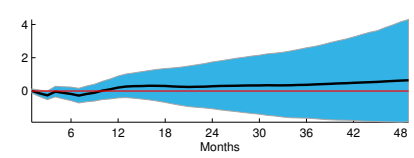

(h)Exchange rate

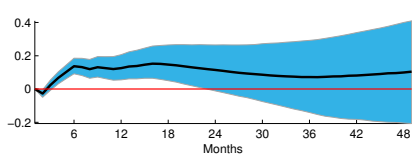

(k)Price Level (CA)

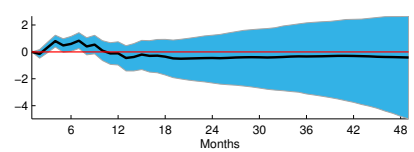

(n)Net Exports (CA)

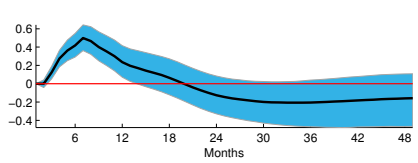

(c)Commodity prices

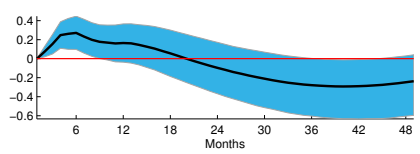

(f)Gov't expenditure (US)

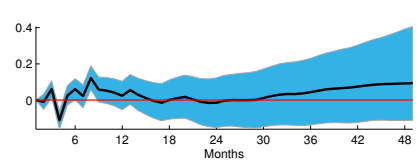

(i)Imports (CA)

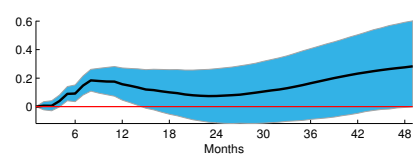

(1)Industrial production (CA)

Note: See figure 3. On $68 \%$ confidence bands reported. 


\section{Appendix D. Robustness - Bank of Canada Reaction Function}

Figure 23. Impulse Response Functions: Canadian Monetary Policy Shock, Alternative Exclusion Restrictions 1

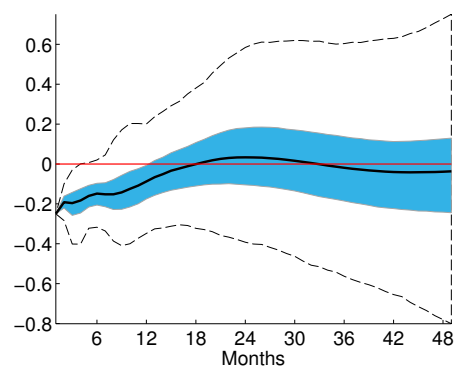

(a) Interest rate

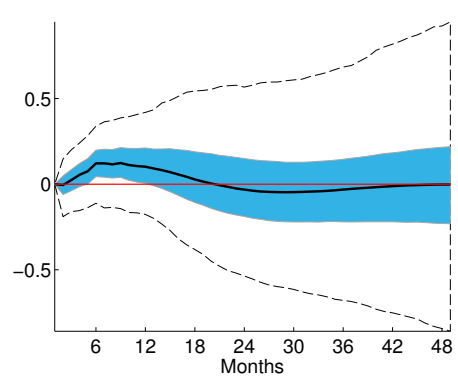

(d)Industrial production

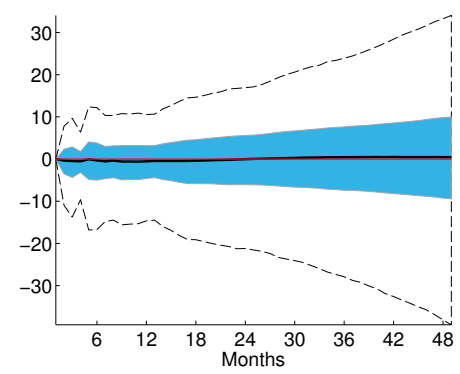

(g)Net Exports

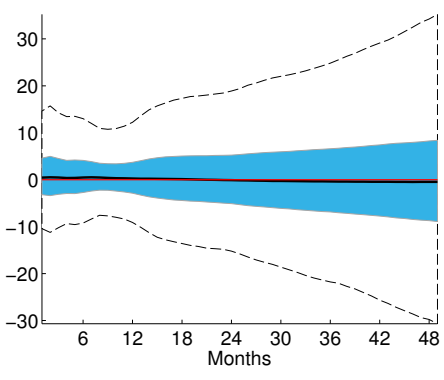

(b)Exchange rate

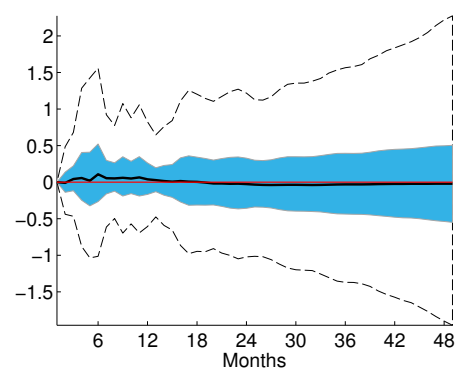

(e)Imports

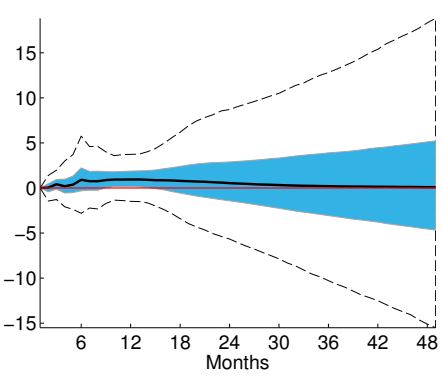

(c)Price Level

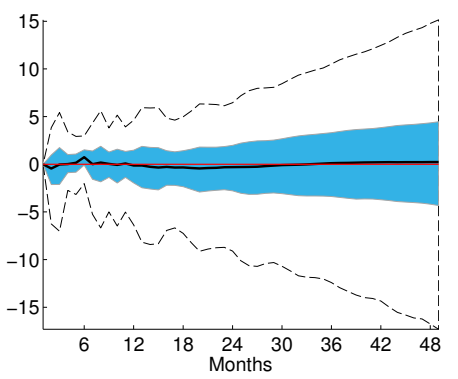

(f)Exports

Note: See Figure 2. 
Figure 24. Impulse Response Functions: US Monetary Policy Shock, Alternative Exclusion Restrictions 1

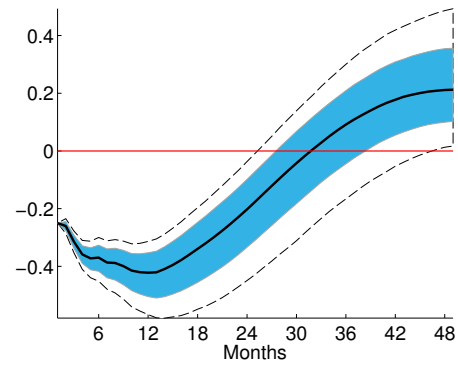

(a)Interest Rate (US)

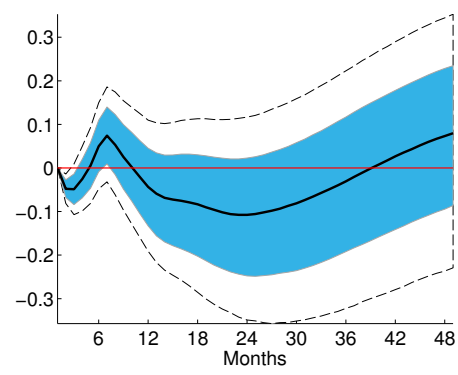

(d)Price Level (US)

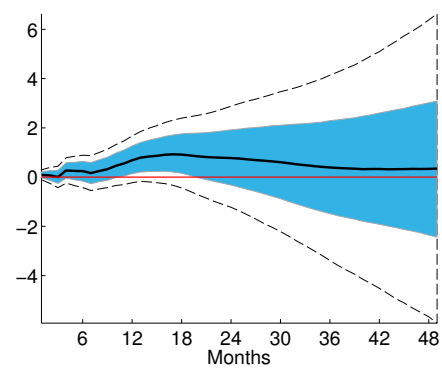

(g)Exchange rate

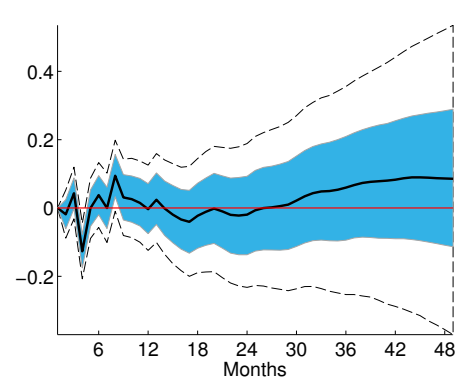

(j)Imports (CA)

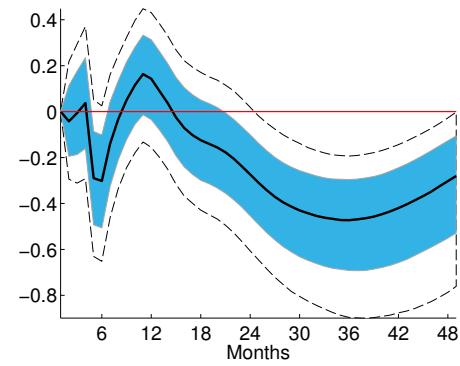

(b) VIX

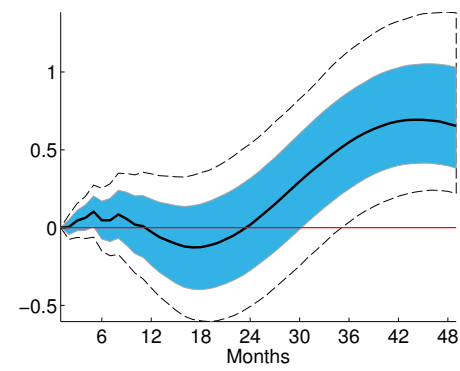

(e)Industrial production (US)

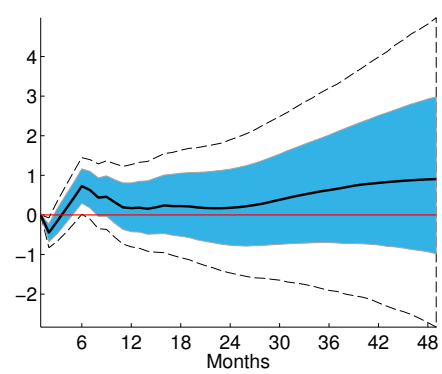

(h)Price Level (CA)

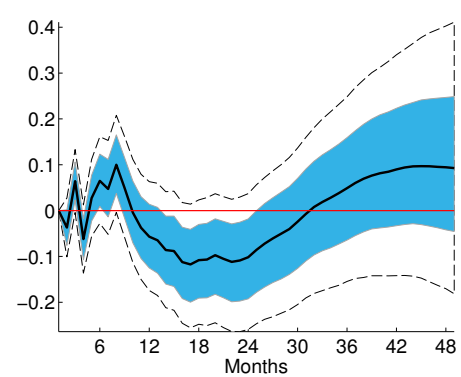

(k)Exports (CA)

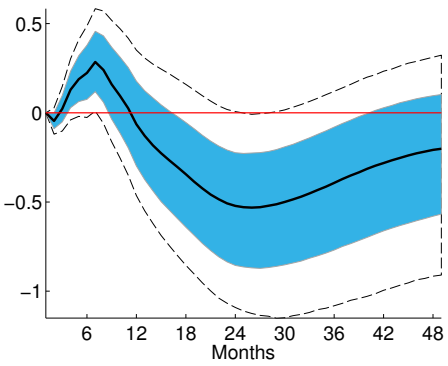

(c)Commodity prices

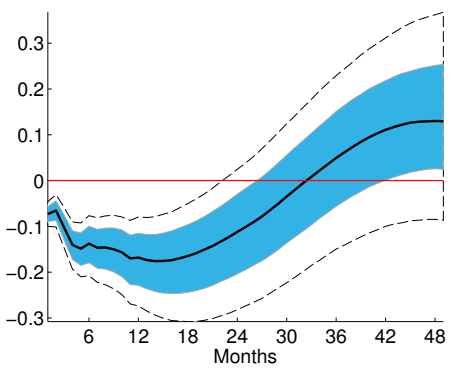

(f)Interest Rate (CA)

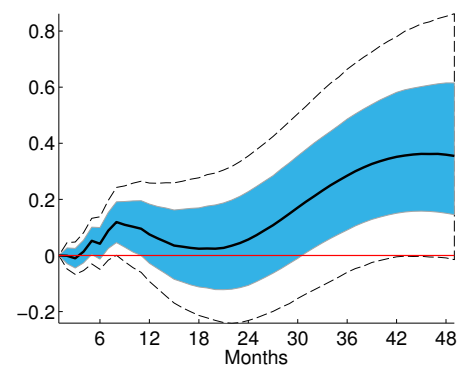

(i)Industrial production (CA)

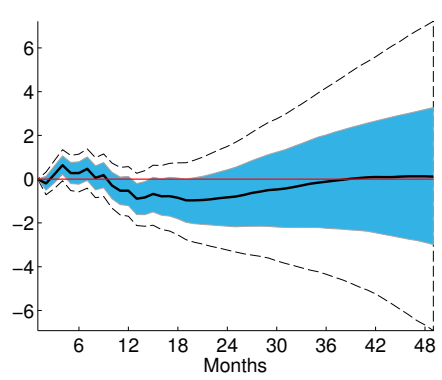

(1)Net Exports (CA)

Note: See Figure 3. 
Figure 25. Counterfactual Paths: Canadian ZLB Imposed, Alternative Exclusion Restrictions 1

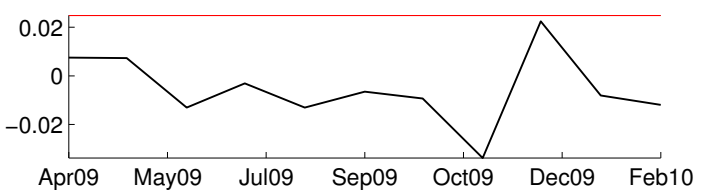

(a)Interest rate

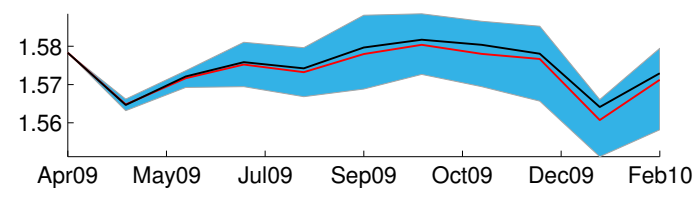

(c)Imports

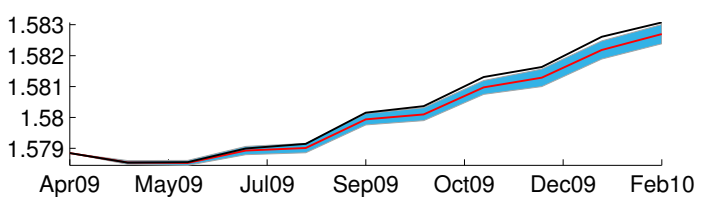

(e)Industrial production

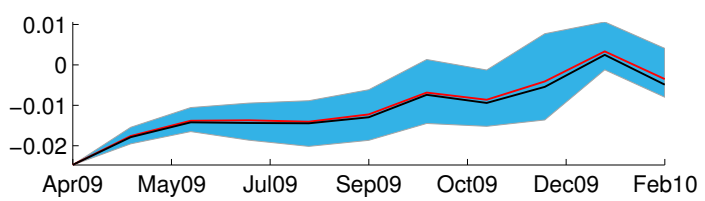

(g)Net Exports

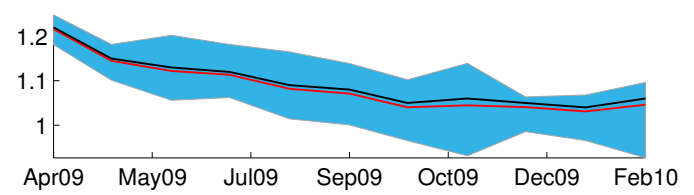

(b)Exchange rate

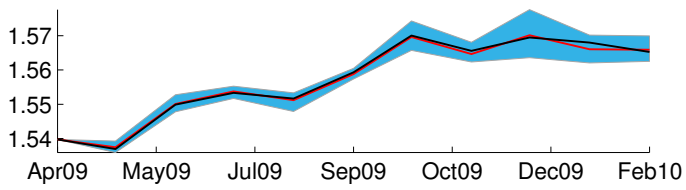

(d)Exports

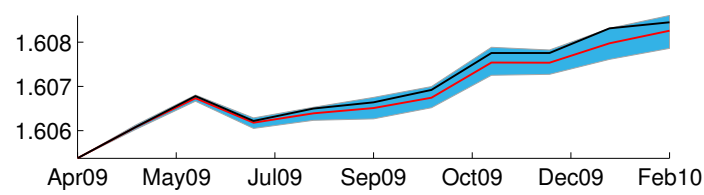

(f)Price Level

Note: See Figure 4. 
Figure 26. Counterfactual Paths: US ZLB Imposed, Alternative Exclusion Restrictions 1

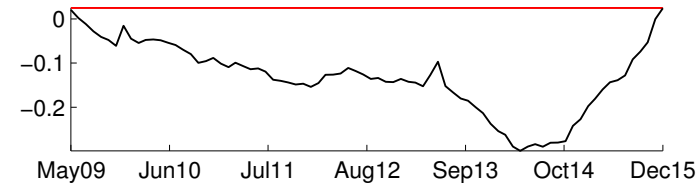

(a)Interest Rate (US)

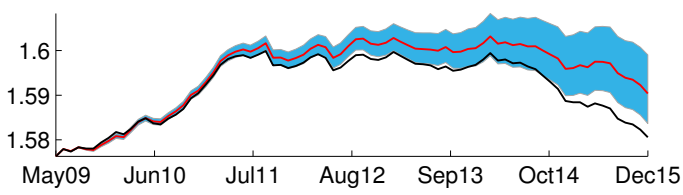

(c)Commodity prices

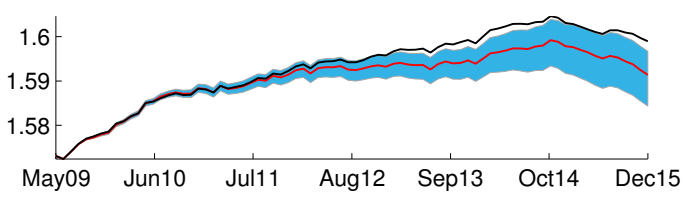

(e)Industrial production (US)

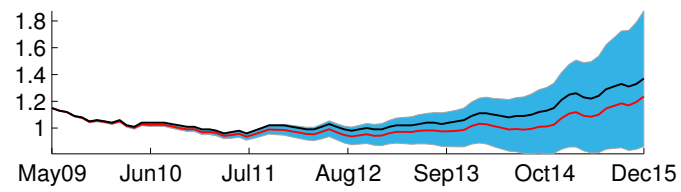

(g)Exchange rate

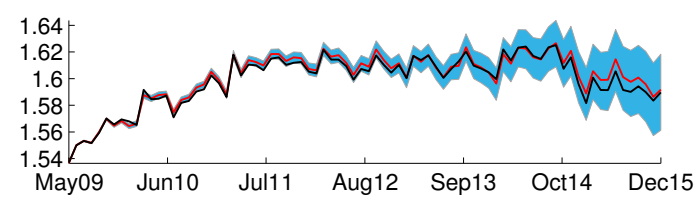

(i)Exports

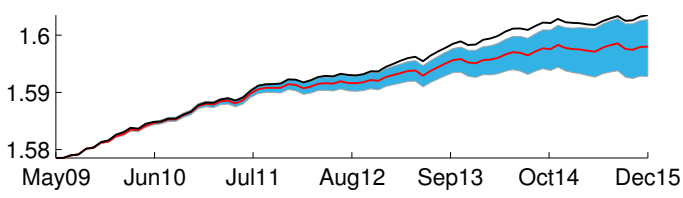

(k)Industrial production

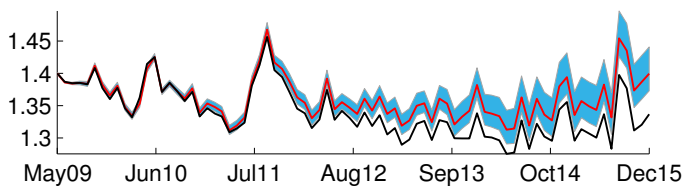

(b) VIX

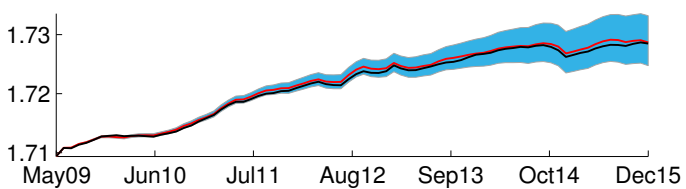

(d)Price Level (US)

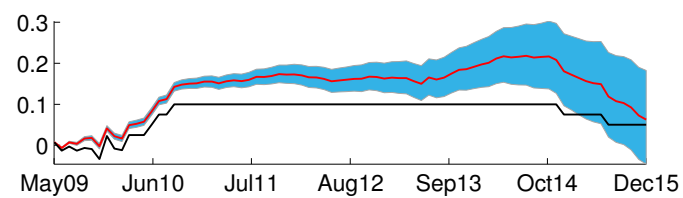

(f)Interest rate

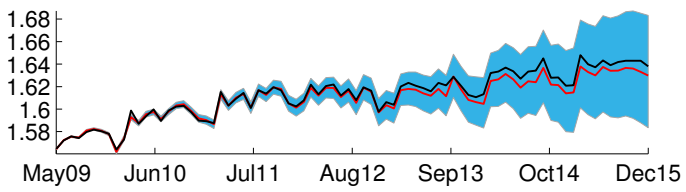

(h)Imports

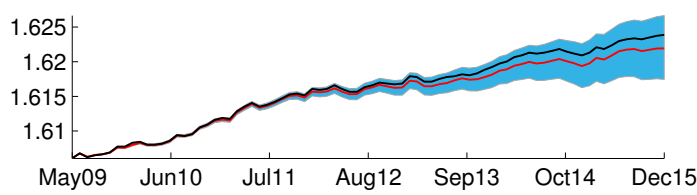

(j)Price Level

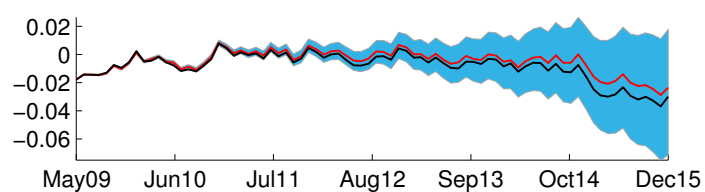

(1)Net Exports

Note: See Figure 5. 